\title{
EFEITOS DO NITROGÊNIO, FÓSFORO, POTÁSSIO E MAGNÉSIO NO CRESCIMENTO, COMPOSIÇÃO MINERAL E QUALIDADES TECNOLÓGICAS DO SORGO SACARINO (Sorghum bicolor L. MOENCH. CV. BRANDES)
}

\author{
ISABEL ETSUE EIMORI
}

Orientador: Prof. EURÍPEDES MALAVOLTA

Dissertação apresentada à Escola Superior de Agricultura "Luiz de Queiroz", da Universidade de São

Paulo, para obtenção do título de Mestre em Agronomia, Área de concentração: Solos $\theta$ Nutrição de Plantas.

$P|R A C| C A B A$

Estado de São Paulo - Brasil

Junho -1986 
A

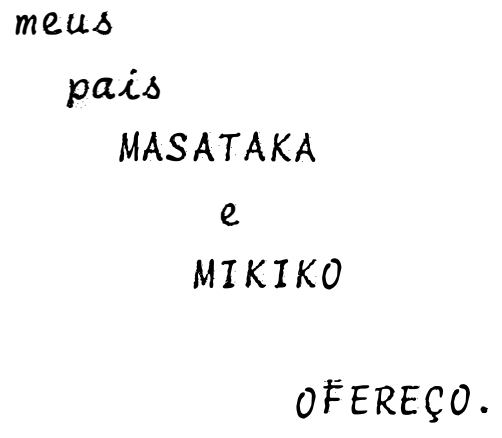

OFEREÇO.

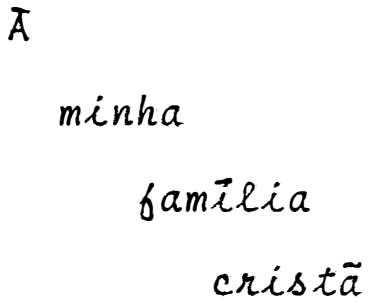

DEDICO. 


\section{AGRADEC I MENTOS}

Ao Prof. Dr. Eurípedes Malavolta, pela orientação, compreen são, carinho e valiosíssimo auxilio prestado.

A FAPESP pelo apoio financeiro.

Ao Centro de Energia Nuclear na Agricultura, USP, Piracica ba, SP, às divisões de Química Analitica e Processamento de Dados pela permissão das anälises químicas e esta tisticas, respectivamente.

Ao Departamento de Tecnologia Rural da Escola Superior de Agricultura "Luiz de Queiroz.", USP, Piracicaba, SP, pelas anālises tecnolögicas.

Aos amigos Alcioneāurea Queiroz da Silva, Humberto Silva, Marco Aurēlio Ribeiro de Castro e Cleusa Cabral, pela colaboração prestada.

A todos que direta ou indiretamente contribuiram para exe cuçao deste trabalho. 
TNDICE

Pàgina

RESUMO $\ldots \ldots \ldots \ldots \ldots \ldots \ldots \ldots \ldots \ldots \ldots \ldots \ldots \ldots \ldots \ldots \ldots \ldots \ldots \ldots$

SUMMARY $\ldots \ldots \ldots \ldots \ldots \ldots \ldots \ldots \ldots \ldots \ldots \ldots \ldots \ldots \ldots \ldots \ldots \ldots \ldots$

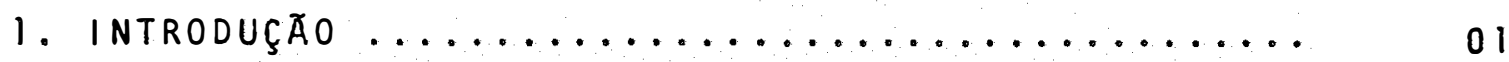

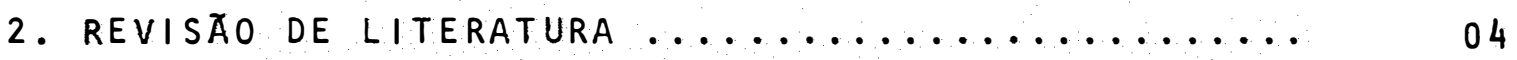

2.1. Produção de colmos e características tecnolögicas em função das doses de N, P e K ... 04

2.2. Diagnose foliar ................... 11

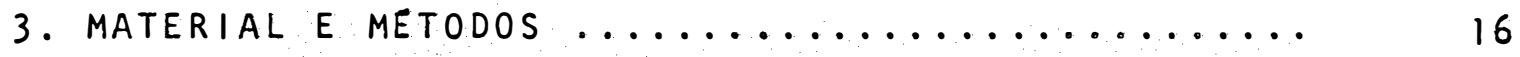

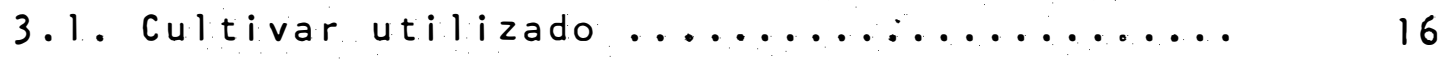

3.2. Experimento preliminar com doses de poẗäs-

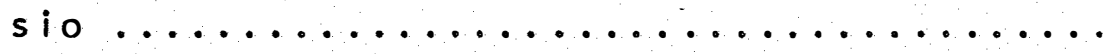

3.2.1. Semeadura e transplante de mudas ... 17

3.2.2. Instal ação dos tratamentos ........ 17

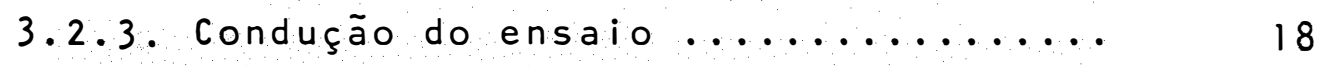

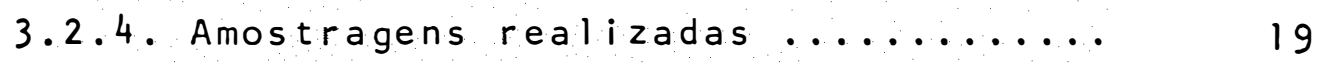

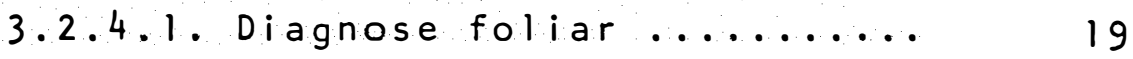

3.2 .4 .2 . Anälise tecnolögica...... 19

3.2.4.3. Determinação da matëria seca 20

$3.2 \cdot 4.4$. Determi nação das exi gências minerais 20

3.3. Experimento com interação $K$ e Mg .......... 21

3.3.1. Semeadura e transplante de mudas ... 21

3.3.2. Instalação dos tratamentos ........ 21

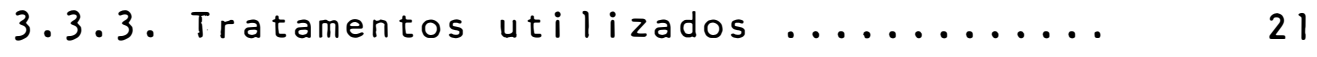

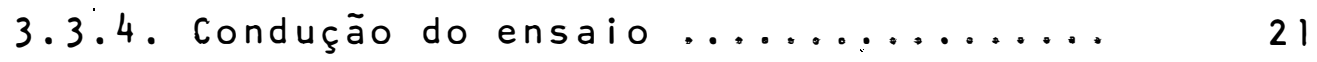

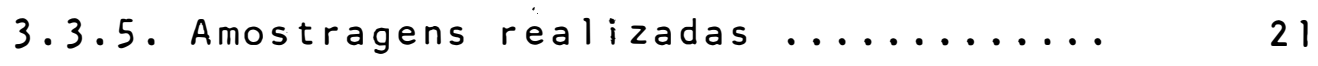

3.3 .5 .1 . Diagnose foliar ......... 21

3.3.5.2. Determinação da matëria seca. 23

3.3 .5 .3 . Anälise tecnolögica ...... 23 
Pàgina

3.4. Experimentos com doses de N, P e K........ 23

3.4.1. Semeadura e transplante de mudas.... 23

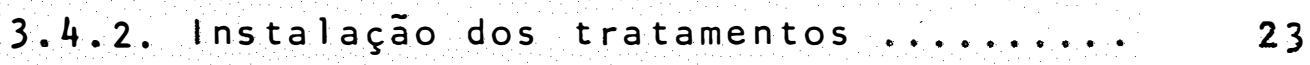

3.4.3. Tratamentos utilizados ............ 23

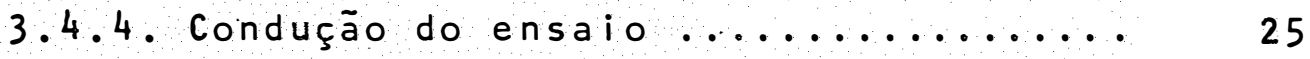

3.4.5. Amostragens realizadas ........... 25

3.4 .5 .1 . Diagnose foliar .......... 25

3.4 .5 .2 . Determinação da matéria seca... 25

3.4.5.3. Anälise tecnolögica ....... 26

3.4.6. Estimativa do rendimento em älcool etilico 27

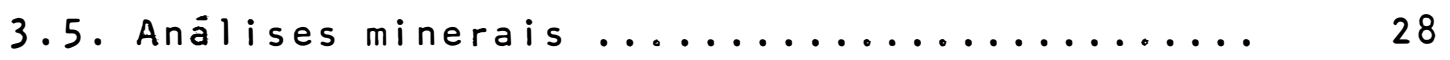

3.6. Delineamento experimental ............. 28

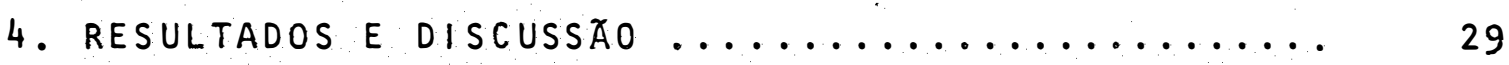

4.1. Efeitos de doses de K (experimento prelimi-

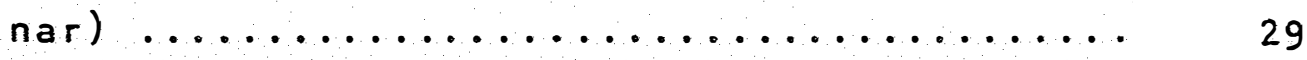

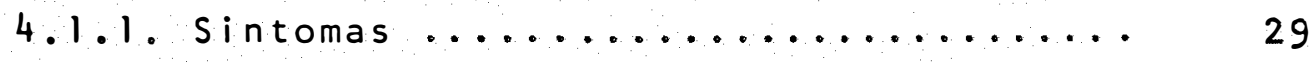

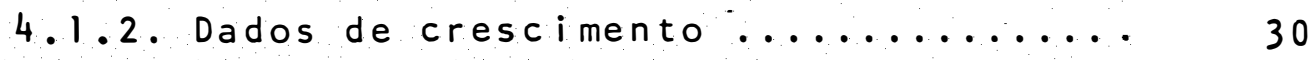

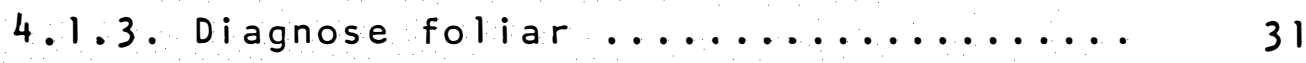

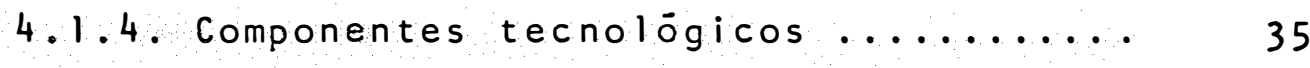

4.1.5. Exigèncias nutricionais .......... 36

4.2. Interação $\mathrm{K}$ e $\mathrm{Mg}$ (segundo experimento) ..... 40

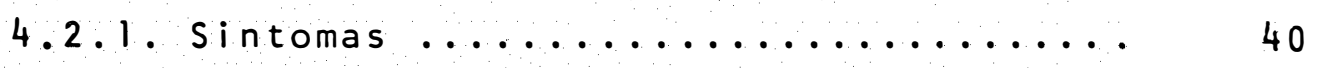

4.2.2. Produção de matèria seca ........... 40

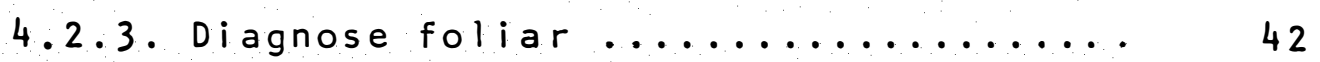

4.3. Efeito de doses de nitrogênio ........... 45

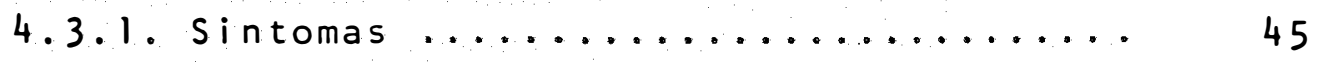

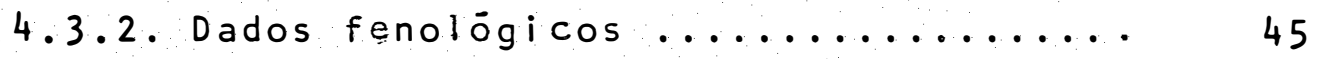

4.3.3. Produção de matèria seca .......... 48

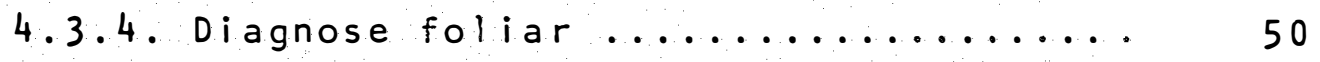

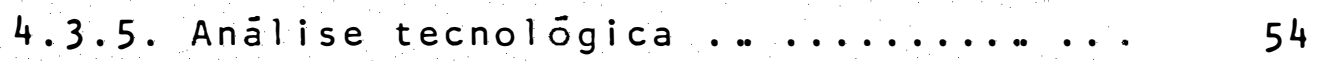


vi.

Pàgina

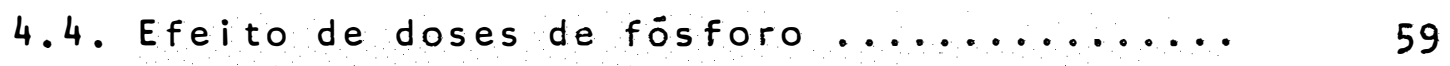

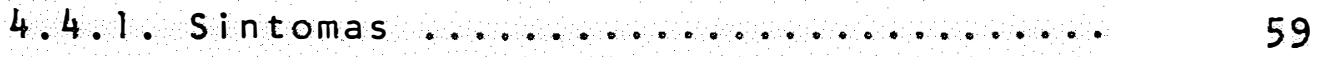

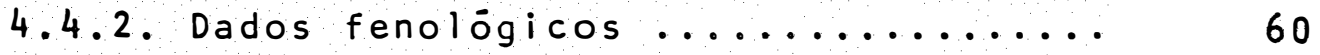

4.4.3. Produção de matéria seca .......... 61

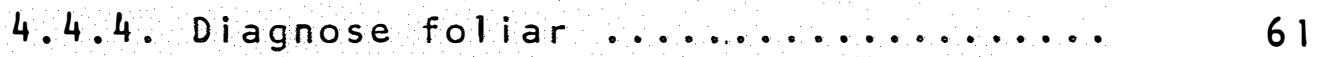

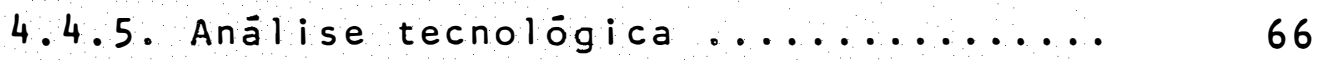

4.5. Efeito de doses de potássio ............. 70

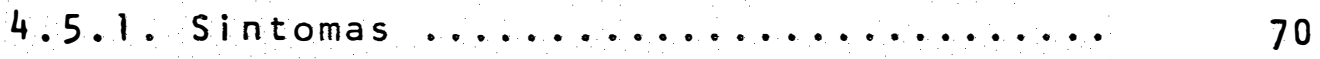

4.5.2. Dados fenolögicos .............. 70

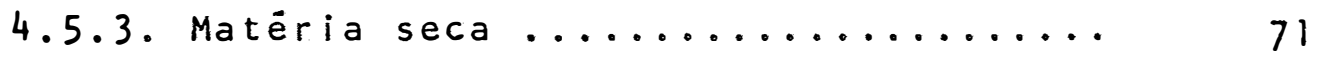

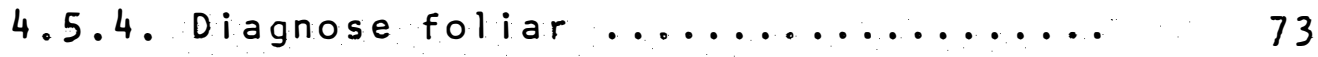

4.5.5. Anälise tecnolögica ............ 78

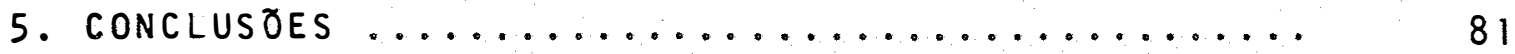

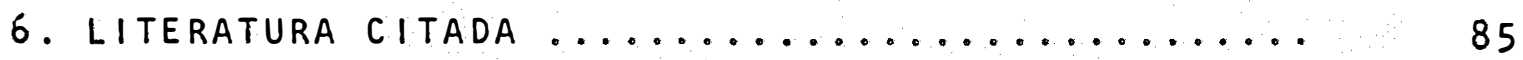


$v i i$.

EFEITOS DO NITROGENIO, FOSFORO, POTASSIO E MAGNESIO NO

CRESCIMENTO, COMPOSIÇĀO MINERAL E QUALIDADES TECNOLOGICAS DO

SORGO SACARINO (Sorgínm bicolor L. Moench. cV. Brandes).

Autor: ISABEL ETSUE EIMORI

Orientador: Prof. EURTPEDES MALAVOLTA

\section{RESUMO}

Em experimentos independentes foi estudado o

efeito de niveis de $K, K$ e $M g, N, P$ e $K$ no crescimento, composição mineral e características tecnolögicas do sorgo sacarino cultivado em solução nutritiva, usando-se a cultivar Brandes.

Os dados obtidos mostraram que a produção de colmos foi influenciada positivamente pelo suprimento de N, P e $K$, tendo havido menor influência do $\mathrm{Mg}$.

Com relação ao nitrogênio, fósforo e potässio, conclui-se que as três premissas básicas da diagnose foliar foram satisfeitas e que os valores obtidos refletem o estado nutricional tão bem quanto relaçóes entre pares de elementos. são considerados como adequados os seguintes niveis foliares determinados em folhas medianas corresponden te a uma produção relativa de colmo igual a $90 \%$ : 
viii.

$$
\begin{aligned}
& N=3,0 \% \\
& P-0,16 \% \\
& K-2,90 \%
\end{aligned}
$$

o rendimento alcoólico estimado diminuiu com a carência de $N$ e $P$, e principalmente com o menor suprimento de K. 
EFFECTS OF NITROGEN, PHOSPHORUS, POTASSIUM AND MAGNESIUM ON GROWTH, MINERAL COMPOSITION AND TECHNOLOGICAL CHARACTERISTICS OF SWEET SORGHUM (SOrghum bicolor L. Moench., cv. Brandes).

\section{Author: ISABEL ETSUE EIMORI}

Adviser: Prof. EURIPEDES MALAVOLTA

\section{SUMMARY}

In independent successive experiments the effects of several levels of $K, K$ and $M g, N, P$ and $K$, on growth, mineral composition and technological characteristics of sweet sorghum were studied under nutrient solution conditions, the cultivar Brandes being used throughout.

Stalk production was positively affected by raising the supply of $N, P$, and $K$, with lesser influence due to $\mathrm{Mg}$.

With respect to $N, P$, and $K$, it was concluded that the three basic premises of foliar diagnosis were obeyed, the obsolente content of the elements in the leaves assessing the nutritional status equally well as the ratios between the percentages of pairs of elements.

The following levels of the elements in medium high leaves sampled, at tillering boot stage, are considered as adequate to give $90 \%$ of the maximum yield: 


$$
\begin{aligned}
& N-3.0 \% \\
& P-0.16 \% \\
& K-2.90 \%
\end{aligned}
$$

The estimated alcoholic yield decreased with the deficiencies of both $N$ and $P$, and especially with lower K supply. 


\section{INTRODUCAAO}

Há uma década, a crise energética causada pela alta no preço do petróleo, no mercado internacional, provocou sérias consequencias para os países em desenvolvimento que importam parcial ou totalmente combustiveis fósseis. Sendo o petróleo um combustivel fóssil, de recurso finito, terá suas reservas diminuidas no futuro, devido ao aumento do consumo mundial. Este panorama despertou a atenção dos países envolvidos, dentre eles o Brasil, para uma investigação dos recursos e necessidades energeticas; procurando estudar a viabilidade do aproveitamento de fontes de energia renováveis em pla no naeional. A criação do Programa Nacional do Alcool em fins de 1975, optou pelo aproveitamento de fontes de energia renováveis, alicerçado na exploração de plantas produtoras de car boidratos a nivel industrial, como matéria-prima para a fabri cação de álcool carburante.

o Brasil, graças à sua extensão territorial e 
disponibilidade de àrea para o cultivo agricola, oferece amplas possibilidades para intensificar esse programa.

No principio pensou-se na possibilidade de ut lização da cana-de-açūcar e da mandioca para a produção de etanol; entretanto, a fim de reforçar o potencial energético do país, fez-se necessärio propor outras matërias primas, que permitissem ampliar consideravelmente a àrea plantada, atravès da utilização de espècies adaptadas a diferentes condições de clima e solo.

Dentro desta perspectiva despontou o sorgo sacarino Sorghum bicolor (L.) Moench. como uma opção a ser estudada. Trata-se de uma gramínea anual que apresenta um rapido desenvolvimento. E explorado tradicionalmente nos Estados Unidos, México e ltälia, para a produção de açücar, xarope, àlcool e outros produtos.

Pertence a familia da cana-de-açūcar, possuindo características semelhantes. Os colmos são ricos em sacarose, glucose e frutose, açūcares de fäcil fermentação, que dispensam a operação de sacarificação, necessāria quando se industrializar os grãos. 0 bagaço pode ser utilizado na produção de energia para o processo industrial. Para o seu processamento são utilizados os mesmos equipamentos exigidos pela cana-de-açūcar, e sua produção se dá na entre-safra desta, o que possibilita a ampliação do período de fabricação de àlcool e consequente redução do período de ociosidade das desti larias. Alēm disso possui ciclo produtivo curto (100-130 dias) e adaptação a amplas condições de crescimenta. 
No Brasil, tem-se conhecimento de trabalhos com sorgo sacarino realizados há $30-40$ anos, no Instituto Agronōmico de Campinas.

o sorgo e originärio da Africa, foi introduzi. do nos Estados Unidos e México em meados do século passado e posteriormente no Brasil.

Embora na atualidade, a cultura tenha uma participação ainda reduzida na economia agräria do país, hä possibilidades de que as variedades sacarinas se tornem matéria prima de real interesse para a produção de älcool.

Alguns estudos tem sido realizados com esta cultura nestes últimos anos. Este trabalho tem o intuito de fornecer mais uma contribuição para o conhecimento da sua nutrição, tratando de:

- obter, através da diagnose foliar, informações que permitam avaliar o estado nutricional;

- estudar o efeito de doses de N, P, K e Mg no cres cimento e nas qualidades tecnológicas (graus brix, açucares redutores (AR), açücares redutores totais (ART) e fibra de plantås cultivadas em solução nutritiva. 


\section{REVISÃO DE LITERATURA}

2.1. Produção de colmos e características tecnológicas em função das doses de $N, P$ e K

Na ocasião em que, a busca de fontes renovaveis de energia como complementação ao uso do petróleo se fez necessäria para o país, o sorgo sacarino, como uma das matérias primas para a produção de älcool carburante, estimulou a pesquisa no sentido de explorar sua potencialidade real de produção. Até então, quando se tratava de nutrição e adubação dessa cultura atribuia-se que a sua exigência era semeIhante ao do sorgo granifero pertencente à mesma espëcie Sorghum bicolor (L.) Moench. Porém os resultados obtidos por MA LAVOLTA et alii (1979) e ROSOLEM (1979) atestaram que as exigências são diferentes, uma vez que a utilização do sorgo gra nífero deve-se a produção de grãos e a do sorgo sacarino se destina a produção de colmo para extração do caldo. 
Em condiçōes de casa de vegetação, ROSOLEM (1979) estudando exigências de nutrição mineral de duas cultivares de sorgo sacarino em solução nutritiva, obteve maior produção de colmos verdes na solução completa, com a cv. Brandes. Na solução diluída a cv. Rio produziu mais que a cv. Brandes. 0 autor concluiu que o sorgo sacarino em condiçōes controladas é bastante exigente em $\mathrm{K}$ e a seguir em $\mathrm{N}, \mathrm{Ca}, \mathrm{Mg}, \mathrm{P}$ e $\mathrm{S}$.

$$
\text { MALAVOLTA et alii (1979), tambēm cultivando }
$$

em solução nutritiva verificaram acentuados decrēscimos na produção de matēria seca total de sorgo sacarino cv. Brandes em meio deficiente em $N$ ou $P$ ou $K$ e comportamentos da seguinte ordem: $-P<-K<-N$. 0 rendimento alcoolico/ha obedeceu a ordem decrescente $-P<-N<-K$.

Vários são os autores que observaram efeitos da adubação de $N, P$ e $K$, em condições de campo, sobre a produção de colmos verdes e características tecnolögicas do sorgo sacarino, como se verà em seguida.

ROSS e WEBSTER (1970) afirmam que o sorgo è uma cultura esgotante do solo, necessitando de adubações pesadas, sendo o nitrogênio o elemento mais limitante da produção; as exigências em $P$ e $K$ são menores que as de nitrogênio.

Entretanto, MACHADO et alii (1982) e ROSOLEM et alii (1982) empregando doses de atè $180 \mathrm{~kg} / \mathrm{ha}$ de $\mathrm{N}$ em um Latossolo Roxo não verificaram efeito na produção de colmos.

Para o estado de Minas Gerais, FONTES e FILHO (1979) relatam recomendações gerais de 30 a $60 \mathrm{~kg}$ de $\mathrm{N} / \mathrm{ha}$ 
para äreas de maior potencial de produção e entre 20 e $40 \mathrm{~kg} /$ ha para áreas com deficiencia hídrica.

CORDEIRO et alii (1982) conduzindo experimento durante dois anos agrícolas, observaram que a resposta do sorgo sacarino à adição de nitrogênio, está associada à preci pitação ocorrida na fase vegetativa da cultura. Portanto, no primeiro ano quando a precipitação foi normal a produção mäxima foi obtida com $172 \mathrm{~kg}$ de $\mathrm{N} / \mathrm{ha}$, enquanto que, no segundo ano com períodos prolongados de seca obteve-se resposta da planta até $210 \mathrm{~kg} \mathrm{~N} / \mathrm{ha}$.

ROSOLEM (1979), em um Latossolo Vermelho Escuro fase arenosa, com $2,07 \%$ de matéria orgânica obteve resposta a aplicação de até $75 \mathrm{~kg} / \mathrm{ha}$ de $\mathrm{N}$, com produção de 37,79 tha de colmo verde, 13,35 s superior a obtida com a testemunha. Com relação às características tecnolögicas como o grau Brix e porcentagem de sacarose, demonstraram tendência a uma diminuição com a elevação da dose de N, na cv. Brandes estudą da, porém na cv. Rio houve tendència de crescimento.

TEDRUS (1982) verificou com a aplicação de 50 e $100 \mathrm{~kg} / \mathrm{ha}$ de $\mathrm{N}$, incrementos na produção de colmos de 13,42 e 17,04 t/ ha, resిpectivamente, em relação a testemunha, mas não obteve efeito na produção de álcool por tonelada de colmo com as doses de $N$.

Ensaio realizado por COUTINHO (1982), mostrou que com a aplicação de $40,80,160$ e $320 \mathrm{~kg} / \mathrm{ha}$ de $N$ foi possí vel obter acréscimos na produção em relação a testemunha de 
48,$2 ; 64,2 ; 58,8$ e $59,1 \%$, respectivamente. Verificou na dose $80 \mathrm{~kg} / \mathrm{ha}$ de $\mathrm{N}$, maior incremento na produção de álcool por tonelada de colmo $(70,0,1)$ e no nível mais elevado de $\mathrm{N}(320 \mathrm{~kg} /$ ha de N) a produção média foi reduzida a $64,71 / \mathrm{t}$ de colmos. Este efeito foi atribuído a uma diminuição no teor de açūcares totais, visto que o $N$ promove crescimento, utilizando-se dos carboidratos produzidos pela fotossintese (BLACK, 1975).

SILVA (1983) relata incrementos na produção de colmos verdes com a adubação nitrogenada na maior dose aplica da $(180 \mathrm{~kg} \mathrm{~N} / \mathrm{ha})$. A adição de doses crescentes de nitrogênio no solo fez com que aumentasse os teores do grau Brix de 17,31 para 19,87; dos açūcares redutores totais (ART) de 14,73 para 16,92\%; dos açücares redutores (AR) de 3,64 para $5,81 \%$ e da sacarose de 9,28 para $10,56 \%$.

ESTEVES et alii (1981) estudando efeitos da época de semeadura em cultivares de sorgo sacarino encontraram produção de 20-40 t/ha de colmos com a aplicação de 60 , 40 e $30 \mathrm{~kg} / \mathrm{ha} \mathrm{de}, \mathrm{P}_{2} \mathrm{O}_{5}$ e $\mathrm{K}_{2} \mathrm{O}$, respectivamente, em solo de textura arenosa e de baixa fertilidade. As crs. Ramada, Rio, Brandes, Roma e Dale foram as que apresentaram caldo bastante rico em açúcares totais. Para a cv. Brandes observaram: 15,56 a 18,47 de ${ }^{\circ}$ Brix; 12,72 a $15,53 \%$ de ART e 10,14 a $12,72 \%$ de sacarose.

Segundo ZANINI (1982) foi demonstrado que se aplicando 60,40 e $30 \mathrm{~kg} / \mathrm{ha}$, respectivamente de $\mathrm{N}, \mathrm{P}_{2} \mathrm{O}_{5}$ e $\mathrm{K}_{2} \mathrm{O}$, obtem-se de 50 a $60 \mathrm{t} / \mathrm{ha}$ de colmos da cv. Brandes, de acordo com as épocas de colheita. 
SERRA et alii (1976) obtiveram produçōes de atè 60 t/ha de colmos com adubaçöes de 80,90 e $90 \mathrm{~kg} / \mathrm{ha}$ de N, $\mathrm{P}_{2} \mathrm{O}_{5}$ e $\mathrm{K}_{2} \mathrm{O}$, respectivamente, em um Latossol Rcxo. No caldo, o teor de açúcares totais foi de 14 a $16 \%$ e de sacarose de 11 a $13 \%$, com o emprego dessa adubação.

MEIRA (1982) obteve uma produção mēdia de colmo de $39,4 \mathrm{t} / \mathrm{ha}$ e $22,5 \mathrm{t} / \mathrm{ha}$ para os tratamentos $75-400-275$ e 75-300-200 kg/ha de $\mathrm{N}_{2} \mathrm{P}_{5}$ e $K_{2} \mathrm{O}$ respectivamente. Nesse ensaio os parâmetros tecnológicos estudados (Produção de caldo, OBrix, Açúcares redutores e Pol) tiveram influência da adubação, para a cultivar Brandes.

Na realidade, as respostas à aplicação de fósforo são menos frequentes que para o nitrogênio, contudo, segundo FONTES e FILHO (1979), há indicações de que sob condições tropicais, as possiveis respostas do sorgo à adubaçãofos fatada possam estar associadas ao uso conjunto de nitrogênio e fösforo devendo as aplicaçōes de 40 e $70 \mathrm{~kg} \mathrm{de} \mathrm{P}_{2}{ }{ }_{5} / \mathrm{ha} \mathrm{man-}$ ter niveis favoráveis do nutriente no solo, exceto nos solos sob vegetação de cerrado, nos quais os teores de fösforo disponíveis são frequentemente inferiores a 2 ppm.

COUT.INHO (1982) verificou incrementos na produção de colmos em relação a testemunha de 74;1.16;137 e $122 \%$, quando adicionou-se $50,100,200$ e $400 \mathrm{~kg} / \mathrm{ha}$ de $\mathrm{P}_{2} \mathrm{O}_{5}$ res pectivamente. Contudo, a produção estimada de älcool por tonelada de colmos não foi afetada pela adubação fosfatada.

Os pesquisadores MACHADO et alii (1982) e ROSO 
LEM et alii (1982) constataram que o emprego de doses de até $300 \mathrm{~kg} / \mathrm{ha}$ de $\mathrm{P}_{2} \mathrm{O}_{5}$ não afetava significativamente a produção de colmos.

CORDEIRO et alii (1982) estudaram os efeitos da adubação fosfatada corretiva e de manutenção na produção de colmos de sorgo sacarino. No primeiro ano verificaram que as maiores produções foram obtidas com doses que variaram de 80 a $120 \mathrm{~kg} / \mathrm{ha}$ de $\mathrm{P}_{2} \mathrm{O}_{5}$, somente com a adubação corretiva. No segundo ano, na mesma àrea aplicou doses de até $150 \mathrm{~kg} / \mathrm{ha}$ de $\mathrm{P}_{2} \mathrm{O}_{5}$ no sulco da semeadura (manutenção) obtendo-se a máxima produção com a dose de $100 \mathrm{~kg} / \mathrm{ha}$ de $\mathrm{P}_{2}{ }^{0}{ }_{5}$

SILVA (1983), constatou maior produção de colmos no tratamento que foi adubado com a dose mais elevada ( 300 $\mathrm{kg} / \mathrm{ha})$ de $\mathrm{P}_{2} \mathrm{O}_{5}(18,88 \mathrm{t}$ de colmo/ha). Com relação ao efeito sobre as características tecnolögicas demonstrou que: o melhor teor do oBrix $(19,68 \%)$ foi obtido com a adição de $100 \mathrm{~kg}$ de $\mathrm{P}_{2} \mathrm{O}_{5} / \mathrm{ha}$, seguido pelo tratamento que levou $300 \mathrm{~kg} / \mathrm{ha}$ de $\mathrm{P}_{2} \mathrm{O}_{5}(19,34 \%)$. O maior teor de açūcares redutores totais (ART) $(17,26 \%)$ no caldo foi alcançado quando utilizou-se a dose intermediäria $\left(200 \mathrm{~kg} \mathrm{P}{ }_{2}{ }_{5} / \mathrm{ha}\right)$. 0 teor de açūcares redutores (AR) no caldo foi menor $(4,67 \%)$ na dose intermediária $(200 \mathrm{~kg}$ $\mathrm{P}_{2} \mathrm{O}_{5}$ /ha) e quanto ao teor de sacarose ocorreu uma redução nos teores à medida que se aumentaram as doses de $\mathrm{P}_{2} \mathrm{O}_{5} / \mathrm{ha}$. 0 teor mais elevado de sacarose foi obtido na dose de $100 \mathrm{~kg} \quad \mathrm{P}_{2}{ }_{5}{ }_{5}$ ha $(11,97 \%)$.

Embora o $K$ constitui-se em um dos nutrientes 
mais exigidos pela cultura do sorgo devido a sua alta concentração nas raízes e no caule $190 \%$ do total dos cátions analisados) (BERTHOULY e GUERRIER, 1979); MACHADO et ali i (1982) e ROSOLEM et alii (1982) não obtiveram respostas significativas na produção de colmos com aplicação de até $180 \mathrm{~kg}$ de $\mathrm{K}_{2} \mathrm{O} /$ ha; isto deve-se a fato provável de que o solo utilizado pelos autores apresentava altos teores de K. Ambos utilizaram um Latossolo Roxo para o cultivo.

CORDEIRO et alii (1982) cultivando em solo de textura arenosa de baixa fertilidade, verificaram uma resposta linear à produçāo de colmos atē a dose de $160 \mathrm{~kg}$ de $\mathrm{K}_{2} \mathrm{O} /$ ha.

Tambēm COUTINHO (1983) obteve acréscimos de 31,$9 ; 65,9 ; 87,0$ e $77,7 \%$, em relação a testemunha, quando adi cionou-se $25 ; 50 ; 100$ e $200 \mathrm{~kg} / \mathrm{ha}$ de $\mathrm{K}_{2} 0$ respectivamente. A adição, deste elemento provocou variações na produção de àlcool por ärea (1/ha), porēm não promoveu al teração na qualidą de do caldo, constituindo-se a produção de älcooll ha função praticamente exclusiva da produção de colmos, conforme predito por ROSOLEM (1979). Este encontrou aumentos na produção de colmos com adubações de 50 a $100 \mathrm{~kg} / \mathrm{ha}$ de $\mathrm{K}_{2} 0$, contudo sem alteração na qualidade tecnológica do caldo. Póde ser visto que ${ }^{\circ}$ Brix variou de 19,4 a 18,5 , a sacarose de 12,0 a $11,6 \%$ e os açücares totais de 16,8 a $15,9 \%$.

Ensaio realizado por RODRIGUES (1981) mostrou que com a aplicação de $75 \mathrm{~kg}$ de $\mathrm{N} / \mathrm{ha}, 400 \mathrm{~kg} \mathrm{P}{ }_{2}{ }_{5} / \mathrm{ha}$ e $275 \mathrm{~kg}$ 
$K_{2} 0 /$ ha foi possível obter produção máxima de caldo (l/ha), po rém a adubação promoveu redução do o Brix do caldo em relação ao tratamento não adubado. o teor variou de 11,81 para 8,08 .

SILVA (1983) obteve maior produção de colmos com a dose $60 \mathrm{~kg}$ de $\mathrm{K}_{2} 0$. A adubação potässica causou variações tais como: um decréscimo no ${ }^{\circ}$ Brix, um decréscimo e elevação se guida no teor de ART, decrēscimo de AR e decréscimo seguido de elevação no teor de sacarose em função dos aumentos nas doses.

Le acordo com a observação feita por FONTES e FILHO (1970) que as necessidades de $K$ não são tão grandes quan to a de nitrogênio, SILVA (1983) verificou que com a dose de $180 \mathrm{~kg} / \mathrm{ha}$ de $\mathrm{N}$ foi possivel obter maior peso de colmos que com a mesma quantidade de $\mathrm{K}_{2} \mathrm{O} / \mathrm{ha}$.

Em sintese, SILVA (1983), relata as seguintes exigências decrescentes para os nut.rientes $N$, $P$ e K, com respeito a produção de colmos verdes na cv. Brandes: $N>P=K$.

SALLES et alii (1977) relatam que os teores. dos parâmetros tecnolögicos da cultivar Brandes, aos 90 e 105 dias de maturação dos colmos, foram: Brix aparente $=14,67 \%$ e $19,1 \%$; açücares redutores totais $=14,62$ e $18,13 \%$ respectiva mente.

\subsection{Diagnose foliar.}

A diagnose foliar é um método utilizado para se avaliar o estado nutricional das plantas. Para tal utili- 
zam-se folhas para determinar a concentração e acūmulo de nutrientes. Os teores foliares se correlacionam razoavelmente com a anälise de solo.

Segundo MALAVOLTA e LOURENĢO (1978), dois fato res são considerados principais para o mëtodo: a amostragem e os níveis críticos físiolögicos ou fisiolögico-económico. Es tes verificaram que os teores de $N, P$ e K em folhas medianas de sorgo granífero, decresciam na seguinte ordem em relação a época de amostragem: perfilhamento, emborrachamento, panícü la e colheita. Resultados satistatórios foram encontrados pe los autores em termos de correlação entre teor foliar e prodü ção nas amostragens efetuadas na época do emborrachamento, to mando-se uma folhada altura mëdia da planta.

Em geral as concentrações de N, P e K decrescem em função da idade da planta oú órgão da planta, enquanto que, as concentrações de $\mathrm{Ca}$ e Mg frequentemente aumentam (MENGEL e KIRKBY, 1982; BERTHOULY e GUERRIER, 1979).

Ao determinar os teores dos nutrientes $\mathrm{N}, \mathrm{P}$ e K em folhas medianas de sorgo sacarino, cv. Brandes, ROSOLEM (1979) encontrou os seguintes intervalos, para os diferentes locais cultivados: em um Latossolo Roxo, 1,83 a $2,52 \%$ de $N$; 0,25 a $0,29 \%$ de $P$ e 1,38 a $1,76 \%$ de $K$, em um Latossolo VermeIho Escuro - fase arenosa; 2,00 a $2,57 \% \mathrm{~N}, 0,43$ a $0,57 \%$ de P e 1,12 a $1,42 \%$ de $K$. 0 autor não verificou correspondência da produção com o elevado teor de p encontrado, e atribuiu como uma das variáveis, as condições climäticas governantes no pe- 
ríodo do ensaio, que podem ter influenciado no desenvolvimento das plantas e concentração de $P$ na folha.

RODRIGUES (1981) obteve, na época do emborracha mento, teores percentuais que variaram de 1,17 a 1,34 para o N, 0,43 a 0,67 para o P, 1,04 a 1,83 para o K, 0,33 a 0,41 pa ra o Ca e 0,38 a 0,47 para $0 \mathrm{Mg}$.

Por sua vez, MEIRA (1982) estabeleceu para a cv. CMS 616 de sorgo sacarino, niveis considerados criticos para os nutrientes $\mathrm{P}$ e Ca, a concentração de $0,33 \%$ e $0,29 \%$ respectivamente.

No estudo sobre a adubação nitrogenada e fosfá tada na cultura do sorgo sacarino, TEDRUS (1982) determinou os teores de $N$ e $P$ existentes nas folhas de posição + 3 . e +4, coletadas em duas épocas de amostragem, aos 45 e 83 dias após a emergência das plantas. Na primeira época de amostragem os teores de $N$ se situaram entre 2,60 a $3,15 \%$, os teores de $P$ entre 0,26 e $0,36 \%$. Na segunda ëpoca os teores de $N$ se situaram entre 2,27 a $3,00 \%$ e os teores de P entre 0,36 e $0,41 \%$. Haven do desta maneira uma diminuição do teor de $\mathrm{N}$ e aumento no teor de P, da primeira para a segunda amostragem.

COUTINHO (1983), na avaliação do efeito da adü bação de N, P e K na cultura do sorgo sacarino, através da diagnose foliar, realizou coletas de folhas da posição +3 e +4 aos 45 e 90 dias após a emergência das plantas. 0s seguin tes intervalos foram obtidos para cada nutriente: na primeira amostragem, $N=2,84$ a $3,22 \%, P=0,243$ a $0,309 \%$ e $K=2,42$ a 
$2,82 \%$; na segunda amostragem, $N=2,79$ a $3,12 \% ; P=0,169$ a $0,253 \%$ e $K=1,40$ a $1,68 \%$. Apesar dos teores terem diminuído da primeira para a segunda amostragem correlacionaram-se pos tiva e significativamente com as produções de colmos. Portanto indicando indiferentes as duas épocas de amostragem.

ROSOLEM (1979), cultivando sorgo sacarino em condif̧ões de casa de vegetação com solução nutritiva, considerou normais os seguintes, como médias os teores de nutrientes nas fo lhas medianas da planta, na época do emborrachamento: $3,20 \%$ de N, 0,80 a $0,95 \%$ de $P ; 2,60$ a $3,10 \%$ de $K ; 0,45$ a $0,65 \%$ de Ca; 0,45 a $0,52 \%$ de $\mathrm{Mg}$.

Em solução nutritiva, MALAVoLta et alii

verificaram os efeitos das deficiencias minerais na produção de matēria seca do sorgo sacarino. As seguintes concentraçōes foliares caracterizaram deficiência dos nutrientes nos diversos tratamentos: $N=1,87 \%, P=0,14 \%, K=0,73 \%, \quad C a=0,40 \%$ (folhas inferiores) e $M g=0,05 \%$ (folhas inferiores) e $0,06 \%$ (folhas superiores). Enquanto que, as concentrações dos ele mentos nas plantas cultivadas em tratamento completo foram: $N=2,36 \% ; P=0,34 \% ; K=1,89 \% ; C a=0,96 \%$ e Mg $=0,75 \%$.

BERTHOULY e GUERRIER (1979) observaram no sorgo que um excesso de $K$ na solução nutritiva impede fortemente - transporte de Ca e Mg. Por outro lado, o K é preferencialmente absorvido quando o $\mathrm{Mg}$ encontra-se em nivel deficiente. EPSTEIN (1975) e MALAVOLTA (1980) atribuem que o antagonismo do potássio sobre o magnésio seja devido a efeitos competitivos na translocação a longa distância. 


\section{OLOGUNDE e SORENSEN (1982) estudando a influ-}

éncia das concentraçōes de $K$ e Mg no sorgo em solução nutriti va verificaram que a produção de matēria seca não foi afetada pelas concentraçōes de $K$ e $M g$ até aos 50 e 75 dias após a emer gência das plantas, respectivamente. A produção māxima de matéria seca foi alcançada com as doses de 195 e 38 ppm de K e Mg respectivamente, entretanto, não encontraram relações de K/Mg que pudessem ser üteis para avaliação do crescimento.

$$
\text { Em sorgo granifero souzA et alii (1976) veri- }
$$

ficaram que existe uma correlação negativa entre a produção de grãos e a relação K/Mg. Observaram que, quando a produção de grãos aumentava de 2,49 para $3,99 \mathrm{t} / \mathrm{ha}$, a relação $\mathrm{k} / \mathrm{Mg}$ de crescia de 0,40 para 0,22 . 
16.

3. MATERIAL E METODOS

o presente trabalho inclui três experimentos conduzidos em casa de vegetação no Centro de Energia Nuclear na Agricultura (CENA) da Escola Superior de Agricultura "Luiz de Queiroz" - USP - em Piracicaba, SP.

Inicialmente fez-se um ensaio preliminar coma finalidade de se estabelecer a dose mínima do elemento em estudo; em seguida foi realizado um ensaio com interação $\mathrm{K} \times \mathrm{Mg}$, variando-se os niveis de $K$ e Mg para se verificar a melhor relação K/Mg na solução nutritiva e na folha; e, por ültimo, fez-se um experimento com doses de $N, P$ e K, numa mesma época.

3.1. Cultivar utilizado

Utilizou-se o cultivar de sorgo sacarino Brandes com ciclo vegetativo de aproximadamente 130-135 dias. 


\subsection{Experimento preliminar com doses de potássio}

\subsubsection{Semeadura e transplante de mudas}

As sementes for am colocadas a germinar em bandejas rasas de polietileno, em substrato de vermiculinta de +7 cm de espessura e recobertas com uma camada de $\pm 1,5 \mathrm{~cm}$, sendo umidecidas com solução de $\mathrm{CaSO}_{4} \cdot 2 \mathrm{H}_{2} \mathrm{O} 10^{-4} \mathrm{M}$.

As plãntulas, com altura de $10 \mathrm{~cm}$ foram transplantadas para bandejas com capacidade de 30 litros, contendo soluçãon: I de HOAGLAND e ARNON (1950) diluída a 1:5, sendo os micronutrientes fornecidos na concentração usual e com o Fe em forma de quelado. A bandeja possuia uma tampa de madeira com furos, nos quais cada plântula era fixada pela região do colo com espuma plàstica.

As soluções permaneceram arejadas durante todo - tempo, com auxílio de capilares acoplados à uma mangueira de borracha, por onde injetou-se ar comprimido.

\subsubsection{Instalação dos tratamentos}

Decorridas duas semanas em solução diluída, cạ da planta selecionada foi transferida para vaso plástico com. capacidade de 2,5 litros contendo solução de tratamento (Tabe la 1).

o arejamento dos vasos foi feito como anterior mente descrito. 
Tabela 1. Composição das soluções nutritivas utilizadas no ensaio de níveis de $K$ em plantas de sorgo sacarino (preliminar).

\begin{tabular}{|c|c|c|c|c|c|c|}
\hline \multirow{2}{*}{$\begin{array}{l}\text { Soluçōes } \\
\text { estoque }\end{array}$} & \multicolumn{6}{|c|}{ Niveis de $k$} \\
\hline & $1: 50$ & $1: 25$ & $1: 10$ & $1: 5$ & $1: 2$ & $1: 1$ \\
\hline $\mathrm{KH}_{2} \mathrm{PO}_{4} \mathrm{M}$ & - & - & - & - & - & 1,0 \\
\hline $\mathrm{KNO}_{3} \mathrm{M}$ & - & - & - & - & - & 3,0 \\
\hline $\mathrm{Ca}\left(\mathrm{NO}_{3}\right) \mathrm{M}$ & 5,0 & 5,0 & 5,0 & 5,0 & 5,0 & 5,0 \\
\hline $\mathrm{MgSO}_{4}$ & 2,0 & 2,0 & 2,0 & 2,0 & 2,0 & 2,0 \\
\hline $\mathrm{NH}_{4} \mathrm{H}_{2} \mathrm{PO}_{4} \mathrm{M}$ & 1,0 & 1,0 & 1,0 & 1,0 & 1,0 & - \\
\hline $\mathrm{NH}_{4} \mathrm{NO}_{3} 0,1 \mathrm{M}$ & 25,0 & 25,0 & 25,0 & 25,0 & 25,0 & - \\
\hline Micro (1) & 1,0 & 1,0 & 1,0 & 1,0 & 1,0 & 1,0 \\
\hline Fe EDTA (2) & 1,0 & 1,0 & 1,0 & 1,0 & 1,0 & 1,0 \\
\hline$K C 10,1 \mathrm{M}$ & 1,2 & 2,4 & 6,0 & 12,0 & 30,0 & - \\
\hline
\end{tabular}

Obs.: $1: 50(0,12 \mathrm{mMK} / 1) ; 1: 25(0,24 \mathrm{mMK} / 1) ; 1: 10(0,60 \mathrm{mMK} / 1)$;

$1: 5(1,20 \mathrm{mMK} / 1) ; 1: 2(3,00 \mathrm{mMK} / 1)$ e $1: 1 \quad(6,00 \mathrm{mMK} / \mathrm{l})$.

(1) em 11 de ägua destilada dissolver: $2,86 \mathrm{~g} \mathrm{H}_{3} \mathrm{BO}_{3} ; 1,8 \mathrm{lg}_{9} \mathrm{MnCl}_{2}$. $4 \mathrm{H}_{2} \mathrm{O} ; \mathrm{O}, 22 \mathrm{~g} \mathrm{ZnO}_{4} \cdot 7 \mathrm{H}_{2} \mathrm{O} ; 0,08 \mathrm{~g} \mathrm{CuSO}_{4} \cdot 5 \mathrm{H}_{2} \mathrm{O} ; 0,02 \mathrm{~g} \mathrm{H}_{2} \mathrm{MOO}_{4} \cdot \mathrm{H}_{2} \mathrm{O}$.

(2) em $700 \mathrm{ml}$ d'ägua destilada dissolver: 26,1 g EDTA (Ácido etilenodiamino tetraacético ou quantidade equivalente de sal sódico), $268 \mathrm{ml} \mathrm{NaOH}(40 \mathrm{~g} / \mathrm{l})$ e $24,9 \mathrm{~g} \mathrm{FeSO}_{4}$, arejar uma noite protegendo da luz, completar a 1 l, guardar em geladeira em frasco escuro.

3.2.3. Condução do ensaio

As soluções nutritivas dos tratamentos foram renovadas quinzenalmente e sempre que necessärio completou-se o volume com ägua destilada. 
Para alguns tratamentos foi necessário a mudan ça da planta para vasos com 5 litros de capacidade.

Durante a condução do experimento houve a taque generalizado de ácaro rajado (Tetranychus urticae) que foi con trolado com aplicação de Acricid $(1 \mathrm{ml} / \mathrm{l})$.

Os sintomas resultantes dos tratamentos foram acompanhados diariamente desde o surgimento até o final da cultura.

\subsubsection{Amostragens realizadas}

3.2.4.1. Diagnose foliar

Aos 40 dias após o transplante para solução de tratamento coletou-se material para avaliação do estado nu tricional pelo método da diagnose foliar. Nesse caso, para cada tratamento foi colhida a folha mediana (+3) (MALAVOLTA e LOURENço, 1978) a qual levou-se para secar em estufa a $\pm 75 \circ \mathrm{C}$, sendo posteriormente moida para determinação dos componentes minerais. Analisou-se os macronutrientes: N, P, K, Ca, Mg e S.

\subsubsection{Anălise tecnolögica}

objetivando-se a anălise tecnológica, estabeleceram-se para amostragem plantas dos tratamentos 1:50, 1:10 e 1:1 ou seja, 0,12 mM, 0,60 mM e 6,00 mM de $K$ na solução respec tivamente, utilizando-se para tal o colmo. 
o critério estabelecido para colheita da amostra foi o estägio de maturação dos grãos, na fase de grãos fari náceos (ROSOLEM, 1979 ).

Os colmos foram pesados isoladamente e depois agrupados para consti tuiremas repetições para anālise. Os mesmos foram desintegrados através de um picador de cana tipo forrageira e logo após o material foi submetido à extração do caldo pelo método da prensa, conforme metodologia apresentada por TANIMO TO $(1964)$.

Analisaram-se as seguintes caracteristicas tecnolögi cas: Brix docaldo, atravēs de refratômetro, acūcares redutores e totais, conforme metodologia de SOMOGY e NELSON modi ficado por AMORIN e ZAGO (1978).

$3 \cdot 2 \cdot 4 \cdot 3$. Determinação da matēria seca

No fim do ciclo, colheram-se 4 plantas para de terminação da produção de matéria seca. Cada planta separada em: raiz, colmo, perfilho, folhas e panícula (raque + grãos), as quais foram secadas em estufa à temperatura de $\pm 750 \mathrm{C}$ e a seguir determinou-se o peso seco das respectivas amostras.

3.2.4.4. Determinação das exigências nutricionais

As amostras, do tratamento $1: 2$, coletadas para determinação da matēria seca, apōs moídas, foram submetidas à digestão para o preparo do extrato e analisados os elementos (macro e micronutrientes). 
3.3. Experimento com interação $\mathrm{K}$ e $\mathrm{Mg}$

3.3.1. Semeadura e transplante de mudas

Idem item 3.2 .1 .

3.3.2. Instalação dos tratamentos

Idem item 3.2 .2 .

3.3.3. Tratamentos utilizados

As doses de $K$ e Mg utilizadas encontram-se na Tabela 2. A solução original de HOAGLAND e ARNON (1950) foi modificada em função das doses de $K$ e $M g$.

3.3.4. Condução do ensaio

A condução deste ensaio realizou-se durante os meses de julho a outubro em vasos de 2,51 de capacidade durante todo o ciclo.

Para o controle de ataque de ácaros fêz-se pul verizações com Acricid $1,5 \mathrm{ml} / 1$ e clorobenzilato a $1 \mathrm{ml} / \mathrm{l}$.

\subsubsection{Amostragens realizadas}

3.3.5.1. Diagnose foliar

A época e a parte amostrada foi como descrito no item 3.3.4. Os elementos analisados foram $\mathrm{K}, \mathrm{Ca}$ e Mg. 
22 .

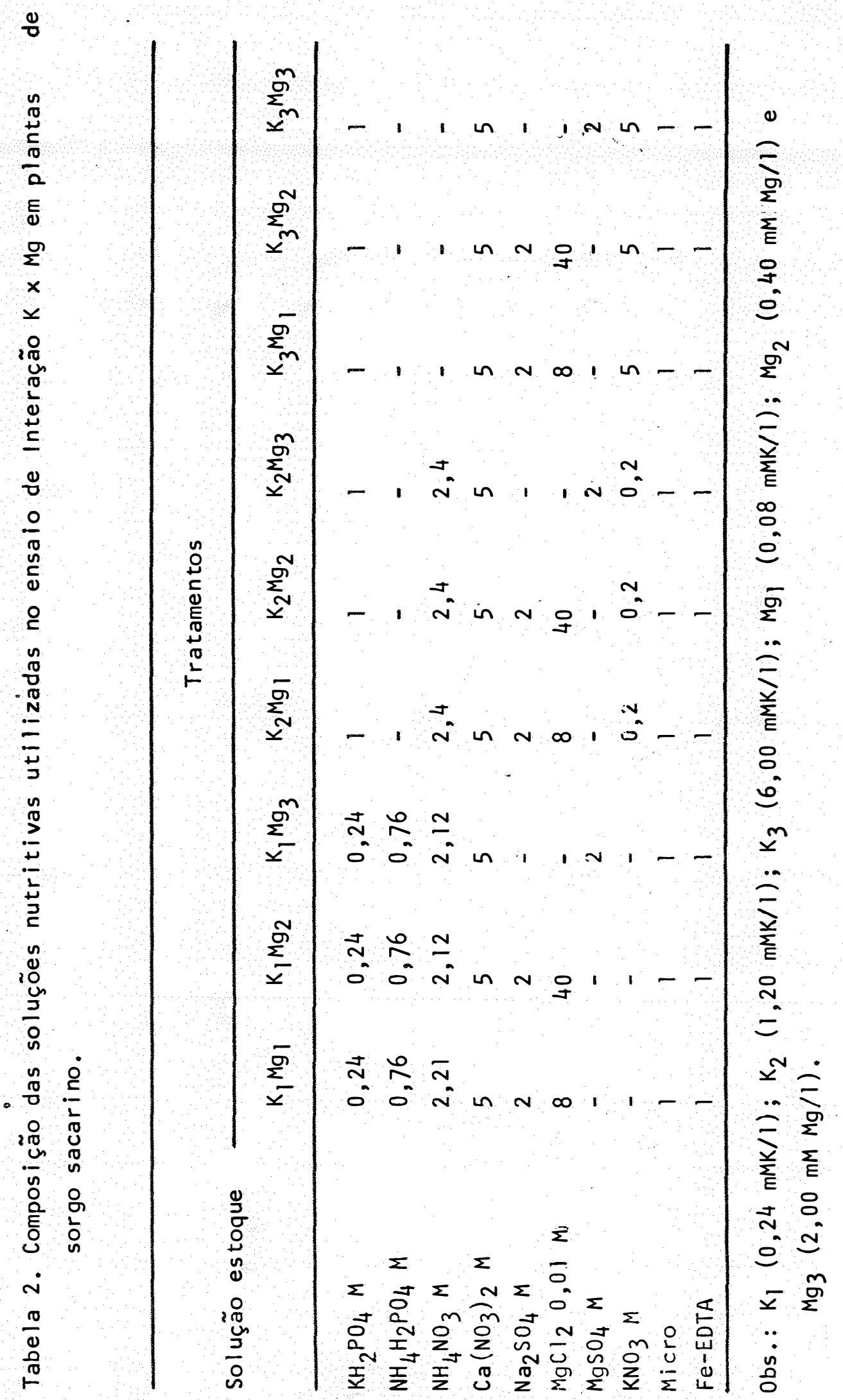


3.3.5.2. Determinação da matèria seca

Idem item 3.2 .4 .3 .

3.3.5.3. Análise tecnológica

Os colmos foram colhidos de maneira semelhante ao descrito no item 3.2.4.2. A extração do caldo foi realiza do em um liquidificador.

Fêz-se medição do Brix (sölidos solúveis) do caldo através de leitura em refratômetro de laboratōrio Modelo AO, corrigida a temperatura do caldo para 209 C.

\subsection{Experimento com doses de $N, P$ e K}

3.4.1. Semeadura e transplante de mudas

Idem item 3.2.1.

3.4.2. Instalação dos tratamentos

- Idem item 3.2.2.

3.4.3. Tratamentos utilizados

As plantas foram cultivadas na solução nutriti va de HOAGLAND e ARNON (1950) ne l com modificações nas doses de $N, P$ e K, conforme a Tabela 3. 


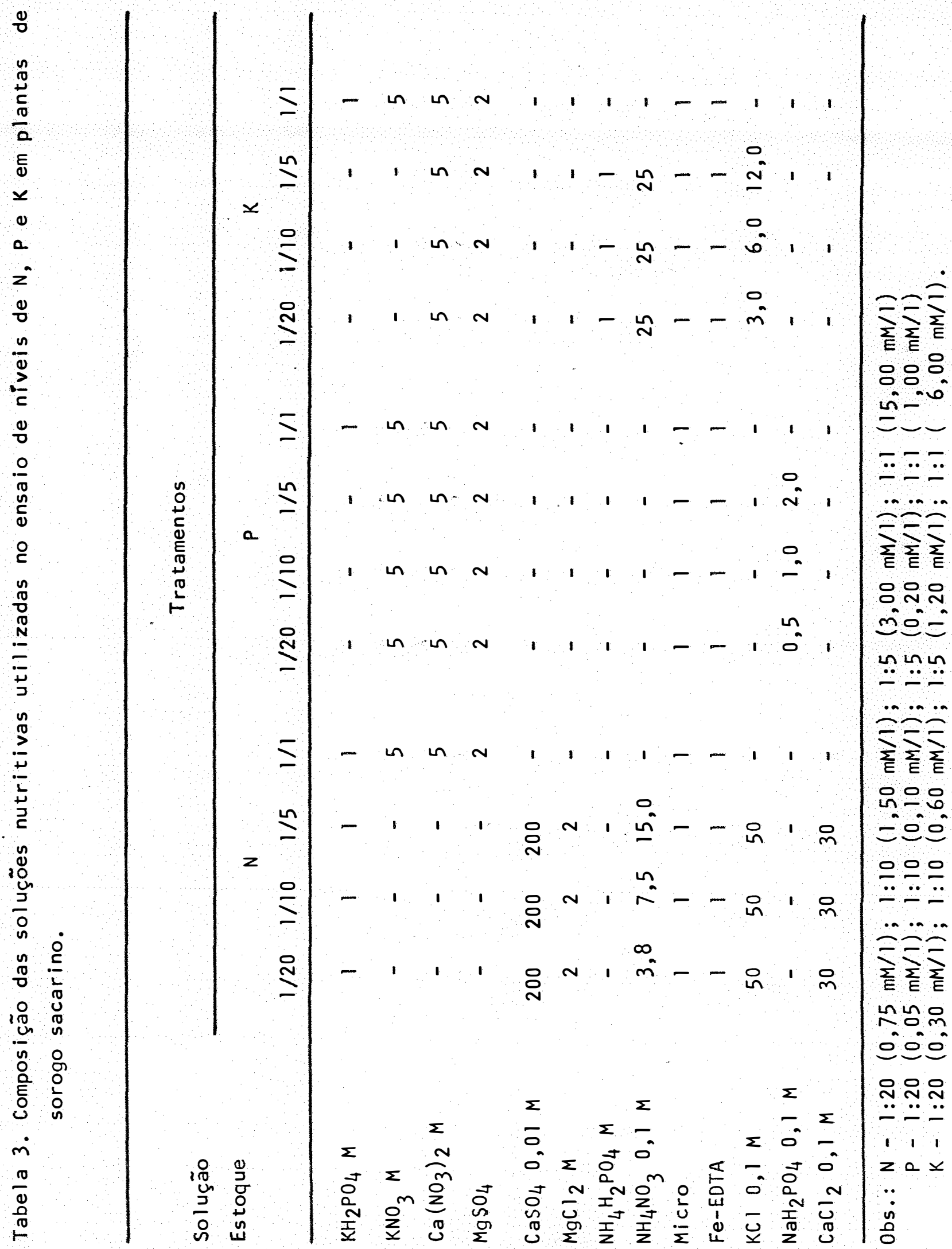


3.4.4. Condução do ensaio

o período de condução se deu a partir da segunda quinzena do mês de outubro.

As plantas cresceram em vasos de 2,5 litros de capacidade até os 60 dias, a partir de então os tratamentos de niveis $1: 1$ e $1: 5$ de $N, P$ e $K$ foram transferidos para vasos de 5 litros de capacidade. Do estádio de emborrachamento até - final do ciclo controlou-se o pulgão (Aphis maydis) com inseticida.

\subsubsection{Amostragens realizadas}

\subsubsection{Diagnose foliar}

Procedeu-se a amostragem para a diagnose foliar colhendo-se folhas de posição +3 , em dois estádios de cres cimento: perfilhamento ( 45 dias após o transplante), emborrachamento ( 78 dias após o transplante).

Determinou-se no material os teores dos seguin tes macronutrientes: $\mathrm{N}, \mathrm{P}, \mathrm{K}, \mathrm{Ca}, \mathrm{Mg}$ e $\mathrm{S}$.

3.4.5.2. Determinação da matéria secà Idem item 3.2 .5 .

Nas plantas colhidas foram medidos o comprimento dos colmos, da altura do colo até o nó da base da pan cula e o diâmetro do colmo, na base do terço médio a partir do äpice. 
3.4.5.3. Análise tecnolögica

As anălises das caracteristicas tecnológicas fo ram feitas para todos os tratamentos de doses de N, P e K Uti lizando-se o colmo.

Após determinação do peso verde fêz-se extração do caldo de acordo com metodologia apresentada por TANIMOTO (1964).

As determinações foram feitas no laboratório de Tecnologia de Açücar e do Álcool do Departamento de Tecnologia Rural da E.S.A. "Luiz de Queiroz".

Analisaram-se as seguintes características tec nológicas e feitos os cálculos:

Porcentagem do caldo

Significa a relação percentual da quantidade de caldo obtida na prensa hidráulica em relação à amostra de colmos desintegrados $(500 \mathrm{~g})$.

\section{Sólidos solüveis (Brix).}

Determinação feita através de leitura em refra tômetro de laboratório Modelo AO, corrigida para temperatura do caldo à $209 \mathrm{C}$.

Açūcares totais do caldo.

Foi realizada determinação na forma de açücares invertidos, após clarificação do caldo com acetato neutro de chumbo, seguido de hidrólise àcida de açücares não redutores e titulação atravēs de método volumétrico de LANE e EYNON (1934). 


\section{Açücares redutores do caldo}

Determinado por titulação direta no caldo extraído, atravēs do método volumétrico de LANE e EYNON (1934). Porcentagem de Sacarose Aparente (PO.I)

Determinado em sacarimetro de peso normal de 26 g, apōs clarificação do caldo extraído com acetato neutro de chumbo a 54,3 Brix, segundo MEADE (1967) e calculada pela seguinte förmula:

$$
\text { Pol\% }=\frac{0,26 \cdot L}{d}
$$

onde $L=$ leitura do sasarimetro;

d = densidade do caldo extraído.

Porcentagem de fibra no colmo.

Calculou-se pela förmula apresentada por TANIMOTO (1964) como se verifica a seguir:

$$
F=\frac{\left(R_{2} \cdot 100\right)-R_{1} \cdot B}{5(100-B)}
$$

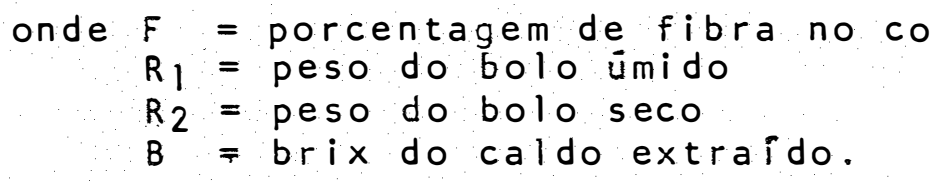

3.4.6. Estimativa do rendimento em àlcool etílico

Para se estimar o rendimento em àlcool etílico, considerou-se uma produção de 35 t/ha de colmo por trata- 
28.

mento, avaliou-se a produção de caldo/ha e em seguida a quantidade de açücares totais/ha.

Considerando-se que 1 mol $(180 \mathrm{~g})$ de glucose produz dois moles $(92 \mathrm{~g})$ de àlcool etílico, e que $100 \mathrm{~g}$ de açücares redutores totais produzem 64,75 moles de álcool etílico, admitiu-se uma eficiência de $9.5 \%$ na extração, $92 \%$ na fermentação, $98 \%$ na des tilação e obteve-se o rendimento em litros de àlcool/ha.

\subsection{Anàlises minerais.}

Em todos os ensaios foram empregados os seguin tes métodos segundo ZAGATO et alii (1981).

$N$ - pelo método semimicro Kjeldahl

P - pelo método de metavanadato

$\mathrm{K}, \mathrm{Ca}, \mathrm{Mg}, \mathrm{Cu}, \mathrm{Fe}, \mathrm{Mn}$ e $\mathrm{Zn}$ - por absorção atômica no extrato nitrico-perclörico.

$S$ - por turbidimetria e.injeção de fluxo contínuo.

B - por colorimetria de curcumina em extrato cloridrico da cinza.

Mg - por colorimetria do tiocianeto em extrato dacinza.

3.6. Delineamento experimental.

o delineamento experimental utilizado foi o in teiramente casualizado para os três ensaios realizados segundo GOMES (1973). O primeiro ensaio constituiu-se de 6 tratamentos, com 4 repetições, perfazendo um total de 24 vasos. 0 segundo ensaio foi constituído por 9 tratamentos, com 4 repetiçōes. Por ültimo, os três nutrientes $N, P$ e K foram testados em 4 doses, totalizando-se 12 tratamentos e as repetições variaram em alguns tratamentos a fim de possibilitar a obtenção de quantidades de colmos suficientes para a anālise tecnológica. 
29.

\section{RESULTADOS E DISCUSSÃO}

4.1. Doses de K (experimento preliminar).

$$
\text { 4.1.1. Sintomas }
$$

Os primeiros sintomas de carência manifestaram se aos 30 dias após o transplante nos niveis $1: 50$ e $1: 25$ de $K$, com uma clorose ao longo das bordas das folhas mais velhas, que progredia na direção da nervura principal. Após es te estädio, estas folhas tornaram-se avermelhadas na região clorótica e secaram.

Os sintomas foram mais severos nas plantas do nivel $1: 50$ e inexistentes nos niveis $1: 1$ e $1: 2$. A severa carência nutricional apresentadas pelas plantas do nível 1:50 determinou o seu corte aos 70 dias após o plantio.

A descrição dos sintomas foram concordantes com o observado por MALAVOLTA et alii (1979). 
4.1.2. Dados de crescimento

A Tabela 4 demonstra que o peso de matéria seca total não diferiu nos tratamentos com diluíção $1: 1 ; 1: 2$ e 1:5 de K na solução, porém houve uma produção superior de col mo nos tratamentos de nivel $1: 2$ seguidos de $1: 5,1: 10$ e 1:1, comparando-se as médias pelo teste de Tukey a $5 \%$.

Tabela 4. Matéria seca (g/vaso) total e das partes da planta de sorgo sacarino, cv. Brandes cultivadas em solução nutritiva com doses de potássio.

\begin{tabular}{|c|c|c|c|c|c|}
\hline Doses de $K$ & Raiz & Colmo & Folhas & $\begin{array}{l}\text { Raquet } \\
\text { grãos }\end{array}$ & Total \\
\hline $1: 50 \quad$ (1) & 1,35 & 2,83 & 8,64 & 0,00 & 12,82 \\
\hline $1: 25$ & $6,03 d$ & $17,56 \mathrm{e}$ & $15,77 \mathrm{~b}$ & $7,96 \mathrm{~d}$ & $48,08 \mathrm{c}$ \\
\hline $1: 10$ & $12,88 \mathrm{c}$ & $52,37 c$ & $33,46 a$ & $30,99 \mathrm{c}$ & $129,70 \mathrm{~b}$ \\
\hline $1: 5$ & $17,37 \mathrm{~b}$ & $60,39 \mathrm{~b}$ & $34,62 a$ & $32,89 \mathrm{bc}$ & $145,27 a b$ \\
\hline $1: 2$ & 22,64 a & 68,11 a & 31,98 a & $39,67 \mathrm{ab}$ & 161,91 a \\
\hline $1: 1$ & $18,88 b$ & $44,61 d$ & $31,20 a$ & $42,63 a$ & $137,32 \mathrm{ab}$ \\
\hline$F$ & $62,15 * *$ & $139,99 * *$. & $4,40 * \pi$ & $58,74 * \star$ & $395,63 * \star$ \\
\hline Tukey $5 \%$ (dms) & 3,38 & 7,18 & 16,10 & 7,78 & 30,46 \\
\hline C.V. \% & 9,84 & 6,76 & 25,06 & 11,55 & 34,00 \\
\hline
\end{tabular}

** significativo ao nivel de $1 \%$

(1) a dose 1:50 de $K$ não foi considerada para fins de anālise estatística.

Médias seguidas de mesma letra não diferem entre si. 
Embora no tratamento $1: 1$ se encontre o K nacon centração maís elevada em relação aos demais, a produção de colmo seco não foi a maior.

Em geral a redução no peso da matēria seca das diferentes partes das plantas foi maior quando se reduziu a concentração de K para $1: 25$.

Tanto ROSOLEM (1979) como MALAVOLTA et alii (1979) ye rificaram comportamentos semelhantes com respeito a decrésci mos nos pesos das matérias secas em virtude dos tratamentos com di luição dos nutrientes em solução nutritiva.

\subsubsection{Diagnose foliar}

Estão na Tabela 5 os dados referentes aos teores de macronutrientes na folha mediana, colhida aos 40 dias, em função dos níveis de $k$.

A observação da Figura l permite evidenciar, pa ra o Ca, decréscimos na sua concentração quando se incremen tou o nível de $K$ na solução. Isto confirma o efeito antagóni co bastante conhecido na literatura entre os cátions $\mathrm{K}$ e Ca (OVERSTREET et alii , 1952; MELLO et alii, 1966; EPSTEIN, 1975; MALAVOLTA, 1980), e a possibilidade de ocorrência de efeito de diluição em função do aumento no desenvolvimento das plantas e consequente produção de colmo, conforme salienta CoUTlNHO (1983) em seu trabalho realizado com adubação potàssica na cultura do sorgo sacarino. Pode-se observar um leve 
Tabela 5. Teores percentuais de nutrientes nas folhas medianas de sorgo sacarino, cv. Brandes, utilizadas para diagnose foliar aos 40 dias do transplante.

\begin{tabular}{|c|c|c|c|c|c|c|}
\hline $\begin{array}{c}\text { Doses de } \\
\text { K }\end{array}$ & $N$ & $P$ & $k$ & $\mathrm{Ca}$ & $\mathrm{Mg}$ & $S$ \\
\hline $1: 50$ & 1,57 a & 1,33 & 0,61 b & $1,99 a$ & $1,01 \mathrm{ab}$ & $2,20 \mathrm{ab}$ \\
\hline $1: 25$ & $1,67 a$ & 1,28 & $0,81 \mathrm{~b}$ & 1,46 ab & 0,81 ab & 2,50 a \\
\hline $1: 10$ & 1,55 a & 1,41 & $0,88 \mathrm{~b}$ & $0,98 \mathrm{bc}$ & $1,09 b c$ & $1,29 \mathrm{c}$ \\
\hline $1: 5$ & 1,51 a & 1,29 & $1,22 b$ & 0,69 bc & $1,17 a$ & $2,37 a$ \\
\hline $1: 2$ & $1,29 a$ & 1,17 & 2,90 a & $0,39 \mathrm{c}$ & $0,55 \mathrm{bc}$ & $1,74 \mathrm{bc}$ \\
\hline $1: 1$ & $1,22 b$ & 1,06 & $3,03 a$ & $0,40 \mathrm{c}$ & $0,54 \mathrm{c}$ & $1,82 \mathrm{~b}$ \\
\hline$F$ & $5,28 *$ & $0,60 \mathrm{~ns}$ & $65,28 * *$ & $21,14 * \star$ & 7,33 * & $24,67 * *$ \\
\hline $\begin{array}{c}\text { Tukey } 5 \% \\
\text { (dms) }\end{array}$ & 0,42 & 0,89 & 0,76 & 0,78 & 0,57 & 0,51 \\
\hline C.V. $(\%)$ & 7,28 & 17,87 & 12,16 & 19,78 & 16,53 & 6,48 \\
\hline
\end{tabular}

* significativo ao nivel de $5 \%$

** significativo ao nivel de $1 \%$

As mëdias seguidas da mesma letra não diferem entre si. 
33.

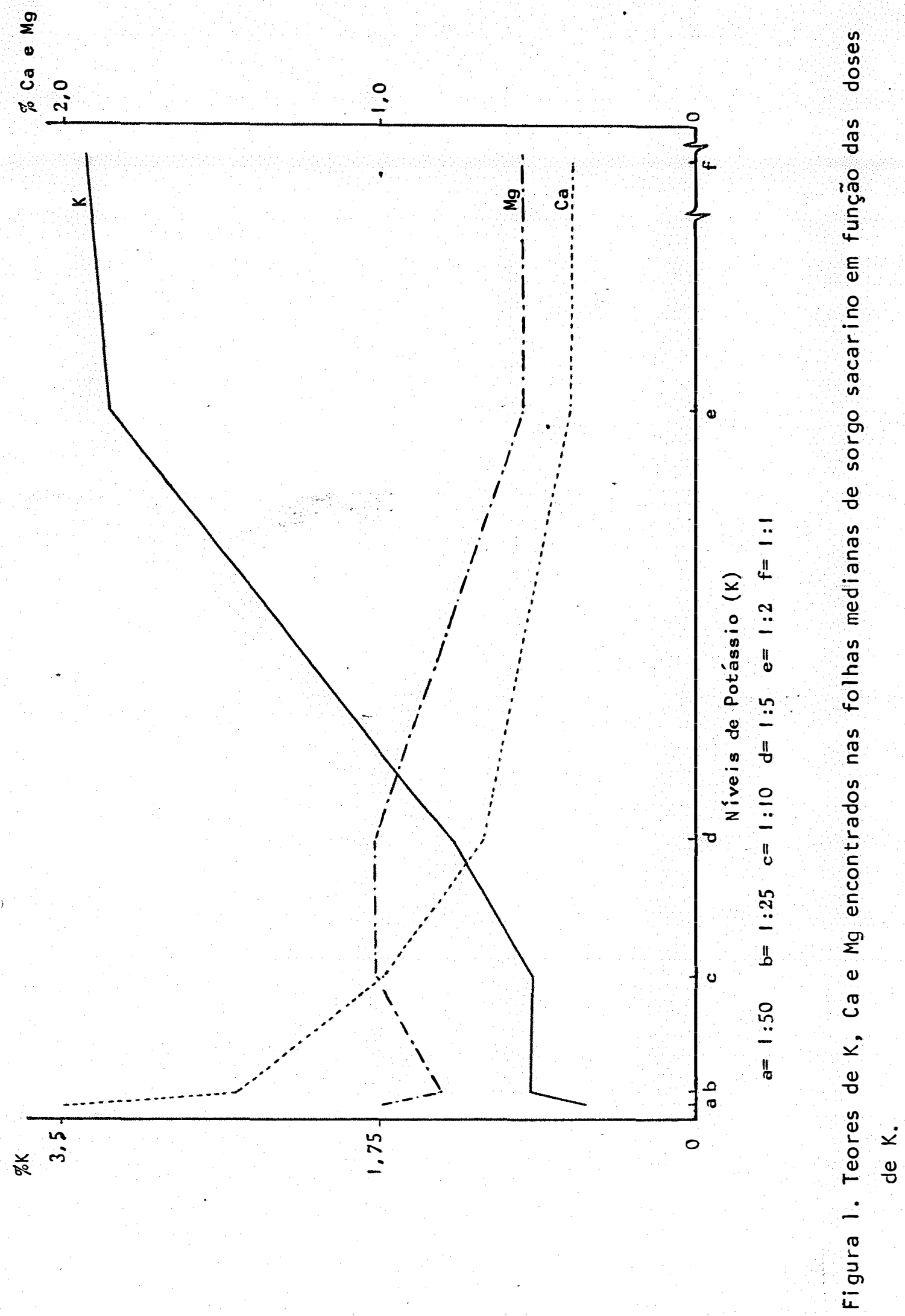


decrēscimo na concentração de Mg em função do incremento de K na solução. Esta interação é relatada por OLUGUNDE e SOREN SEN (1982) e BERTHOULY e GUERRIER (1979) na cultura do sorgo.

A maior produção de matēria seca neste ensaio esteve associada às seguintes relações: $\mathrm{K} / \mathrm{Ca}=7,43 \mathrm{e} \mathrm{K} / \mathrm{Mg}=$ 5,27. COUTINHO (1983) encontrou correlação significativa dos quocientes entre as concentrações de cátions $\mathrm{K} / \mathrm{Ca}$ e $\mathrm{K} / \mathrm{Ca}+\mathrm{Mg}$ nas folhas com a produção de colmos e observou que, uma varia ção mëdia de duas unidades ou menos no quociente $\mathrm{K} / \mathrm{Ca}$ ou $\mathrm{K} /$ Ca+Mg nas folhas pode significar acrēscimos na produção de $20 \mathrm{t} / \mathrm{ha}$ de colmos a mais.

os efeitos positivos das doses do adubo potássico sobre a concentração de $K$ na folha de sorgo sacarino foram verificados por ROSOLEM (1979), COUTINHO (1983) e SILVA $(1983)$

Os teores de $k$ menores que $1,22 \%$ indicam deficiência, enquanto que teores maiores que $2,90 \%$ correspondem a uma nutrição potássica adequada. 0 intervalo adequado esta belecido por ROSOLEM (1979) esteve entre $1,41-1,72 \%$ de $\mathrm{K}$ em folhas da posição +3 colhidas no estädio do emborrachamento,e o de COUTINHO (1983) se situaramentre os intervalos 2,59 a $2,66 \%$ nas folhas da posição +3 , colhidas aos 45 dias apōs a emergência e 1,60 a $1,67 \%$ em folhas +3 , aos 90 dias da emergência das plantas. 
4.1.4. Componentes tecnológicos

Os resultados dos componentes tecnológicos obtidos nos tratamentos de níveis $1: 10$ e $1: 1$ de K encontram-se na Tabela 6 .

Tabela 6. Componentes tecnológicos do colmo de sorgo sacarino cv. Bran des cultivados em solução nutritiva completa e o k diluido a 1:10.

\begin{tabular}{|c|c|c|c|c|}
\hline \multirow{2}{*}{ Componentes } & \multicolumn{2}{|l|}{$1: 10$} & \multicolumn{2}{|c|}{$1: 1$} \\
\hline & $\%$ do caldo & 9 & $\%$ do caldo & 9 \\
\hline Peso do caldo & - & 136,70 & - & 211,17 \\
\hline Brix & 8,30 & 11,35 & 10,00 & 21,12 \\
\hline $\begin{array}{l}\text { Açucares redutores } \\
\text { totais }\end{array}$ & 5,83 & 8,00 & 4,26 & 9,00 \\
\hline Açücares redutores & 2,15 & 2,94 & 1,77 & 3,74 \\
\hline Sacarose & 3,68 & 5,03 & 2,50 & 5,28 \\
\hline Fibra (\% colmo) & 6,20 & & 9,40 & \\
\hline
\end{tabular}

Estes encontram-se abaixo dos teores mínimos obtidos por SERRA (1979), ROSOLEM (1979), ZANINI (1982) e SILVA (1983) em condiçũes de campo e por MALAVOLTA et alii (1979) em solução nutritiva. Isto possivelmente se explica por difirenças nas condições experimentais. 


\subsubsection{Exigências nutricionais}

Nas Tabelas 7 e 8 encontram-se respectivamente os teores e as quantidades de macro e micronutrientes contidos nas diferentes partes da planta de sorgo sacarino no final do ciclo. Na Tabela 9 aparecem as quantidades de nutrien tes exigidas para uma população estimada de 50.000 plantas/ha, que seguiu a seguinte ordem decrescente: $\mathrm{K}>\mathrm{N}>\mathrm{Ca}>\mathrm{S}>\mathrm{P}>$ $\mathrm{Mg}$ e $\mathrm{Fe}>\mathrm{Mn}>\mathrm{Zn}>\mathrm{B}>\mathrm{Cu}>\mathrm{Mo}$. Na ordem de exigência de ma cronutrientes, o K tem vindo em primeiro lugar seguido do $\mathrm{N}$, sendo concordante com trabalhos realizados com a mesma cultivar em casa de vegetação por MALAVOLTA et alii (1979) e ROSOLEM (1979). Quanto à ordem de micronutrientes também está de acordo com o obtido por MALAVOLTA et alii (1979).

A exportação denutrientes, pelocolmo, do total absorvido foi de $37 \%$ de N, $38 \%$ de P. $59 \%$ de $\mathrm{K}, 14 \%$ de $\mathrm{Ca}, 40 \%$ de $\mathrm{Mg}, 14 \%$ de $\mathrm{S}$, $17 \%$ de $\mathrm{B}, 36 \%$ de $\mathrm{Cu}, 6 \%$ de $\mathrm{Fe}, 32 \%$ de $\mathrm{Mn}, 35 \%$ de Mo e $21 \%$ de

Zn. A ordem decrescente de exportação foi a seguinte: $K>$ $\mathrm{N}>\mathrm{P}>\mathrm{Ca}>\mathrm{Mg}>\mathrm{S}$ e $\mathrm{Mn}>\mathrm{Fe}>\mathrm{Zn}>\mathrm{B}>\mathrm{Cu}>\mathrm{Mo}$. Os dados obtidos por MALAVOLTA et alii (1979) foram: $\mathrm{K}>\mathrm{N}>\mathrm{Ca}>\mathrm{S}>$ $\mathrm{Mg}>\mathrm{PeFe}>\mathrm{Mn}>\mathrm{Zn}>\mathrm{B}>\mathrm{Cu}>$ Mo e por ROSOLEM (1979) obedeceram a ordem decrescente $\mathrm{K}>\mathrm{N}>\mathrm{Mg}>\mathrm{P}>\mathrm{S}>\mathrm{Ca}$ e $\mathrm{Fe}>$ $\mathrm{Cu}>\mathrm{Mn}>\mathrm{Zn}$. 
37.

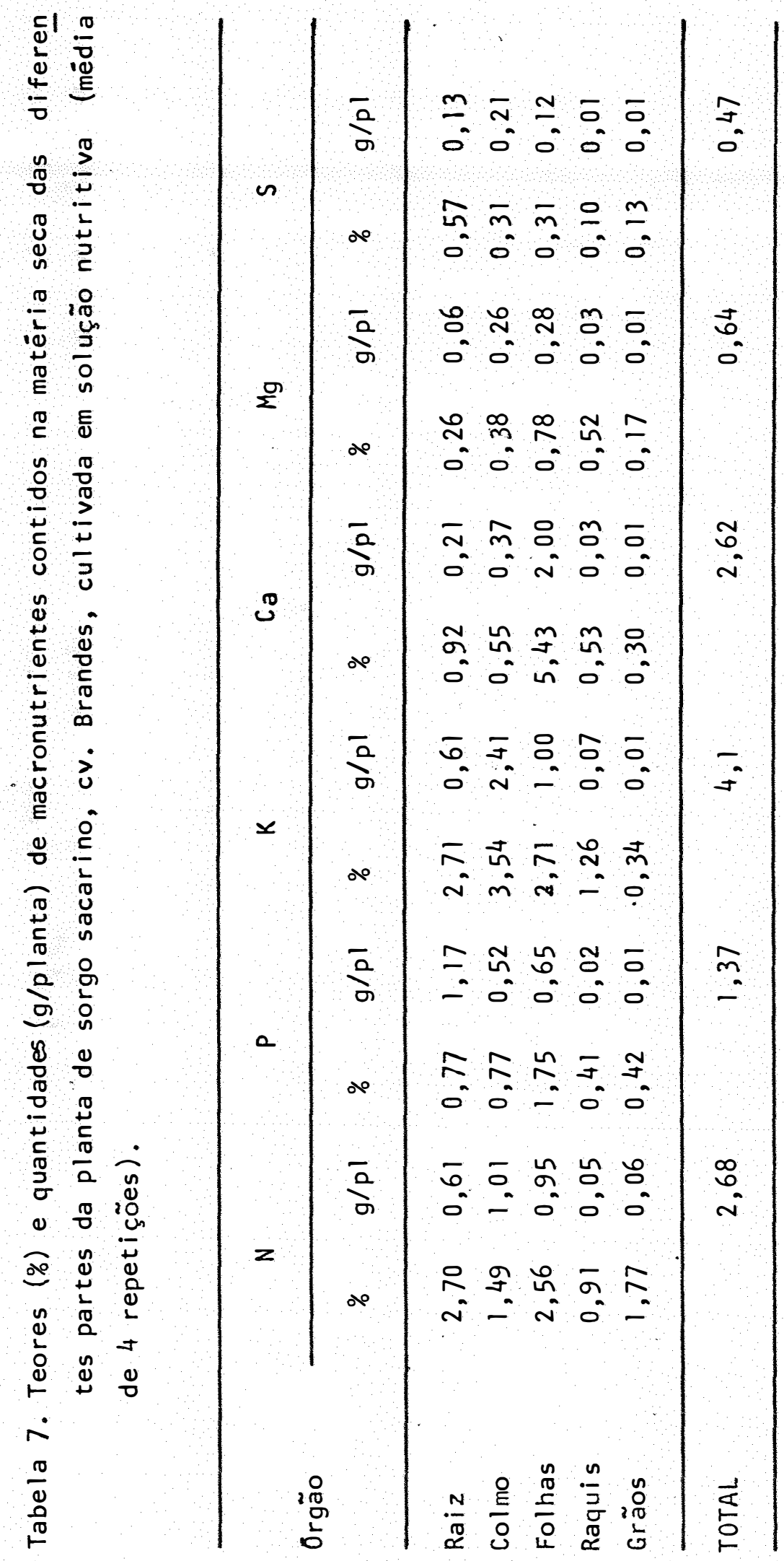




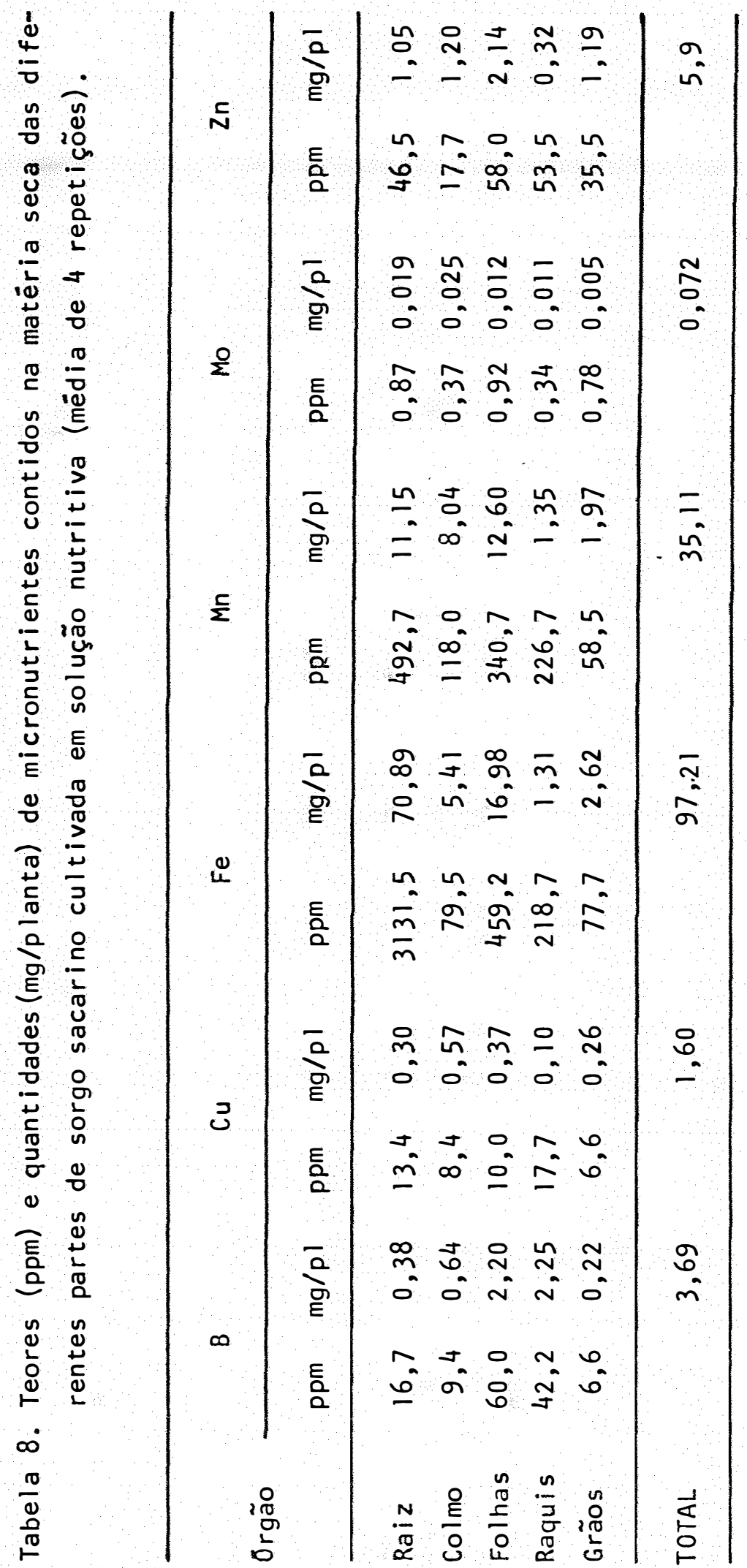




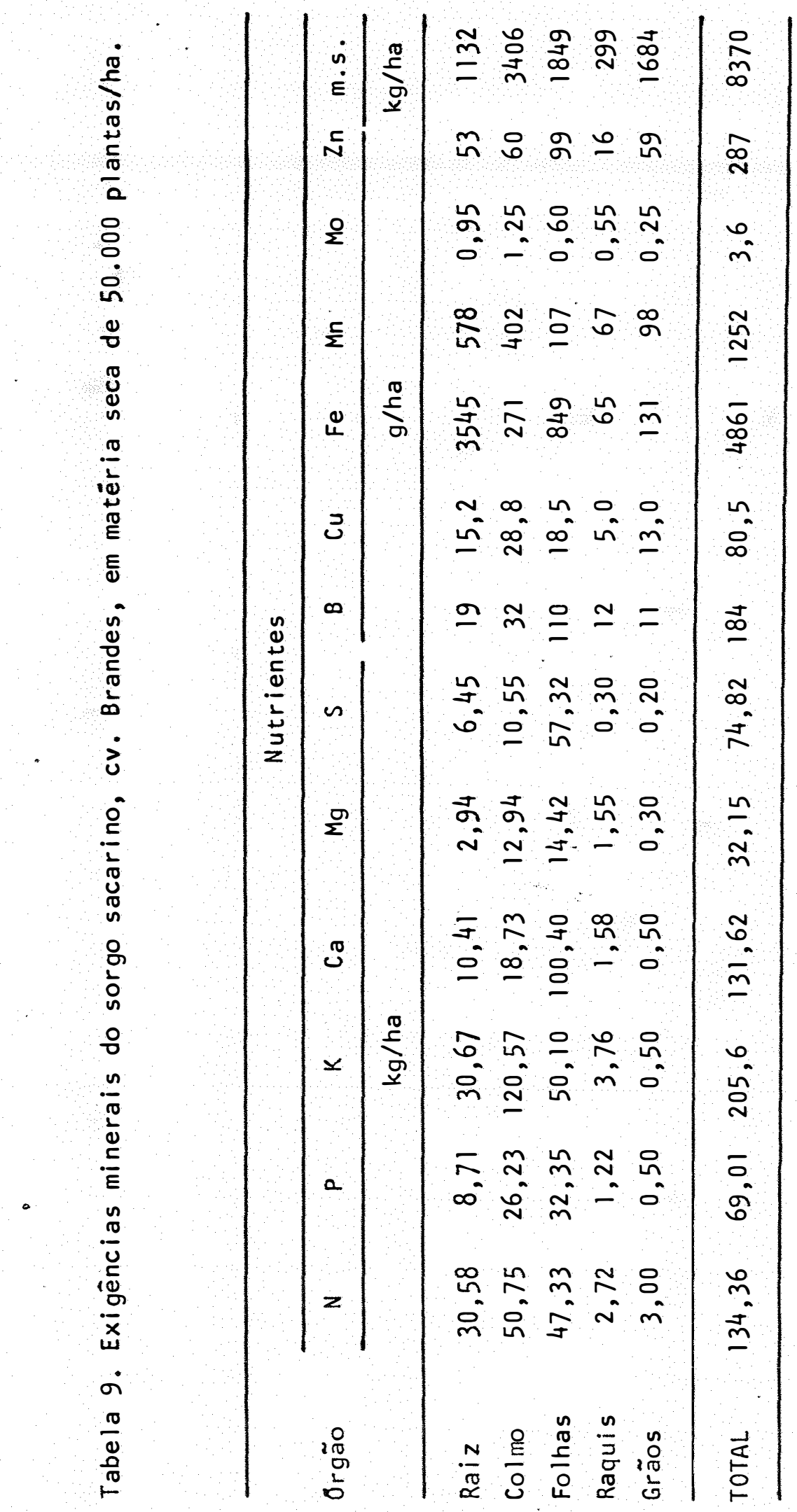




\subsection{Interação $K$ e $M g$ (segundo experimento)}

\subsubsection{Sintomas}

Os sintomas visíveis de deficiência apareceram aos 17 dias após o transplante no tratamento $\mathrm{K} / \mathrm{Mg}$, com nível de $\mathrm{K}$ e Mg mais baixo na solução. Nas folhas mais velhas houve o aparecimento de uma clorose ao longo das bordas e pontua çöes avermelhadas no tecido internerval, que se estendia no sentido longitudinal da lâmina foliar e no estádio mais avanfado as folhas tornavam-se secas.

Para os tratamentos que receberam niveis $\mathrm{K}_{2}$ e $\mathrm{K}_{3}$ e $\mathrm{Mg}_{2}$ e $\mathrm{Mg}_{3}$, os sintomas apresentavam-se gradativos, isto $\ddot{e}$, a clorose das pontas e das margens da folha progredia na direção da nervura principal acompanhada com manchas avermelhadas no tecido internerval.

\subsubsection{Produção de matēria seca}

Com os dados de acumulação de matēria seca cons tantes na Tabela 10 , constata-se que houve decréscimo no desenvolvimento das plantas, quando as concentrações de $\mathrm{K}$ e Mg na solução nutritiva foram diluídas 25 vezes ( $k_{1}$ e $M g$, ) em re lação ao tratamento completo $\left(\mathrm{K}_{3} \mathrm{Mg}_{3}\right)$.

A comparação das mëdias, pelo teste de Tukey a $5 \%$, revelou que a matéria seca total sofreu descréscimo 


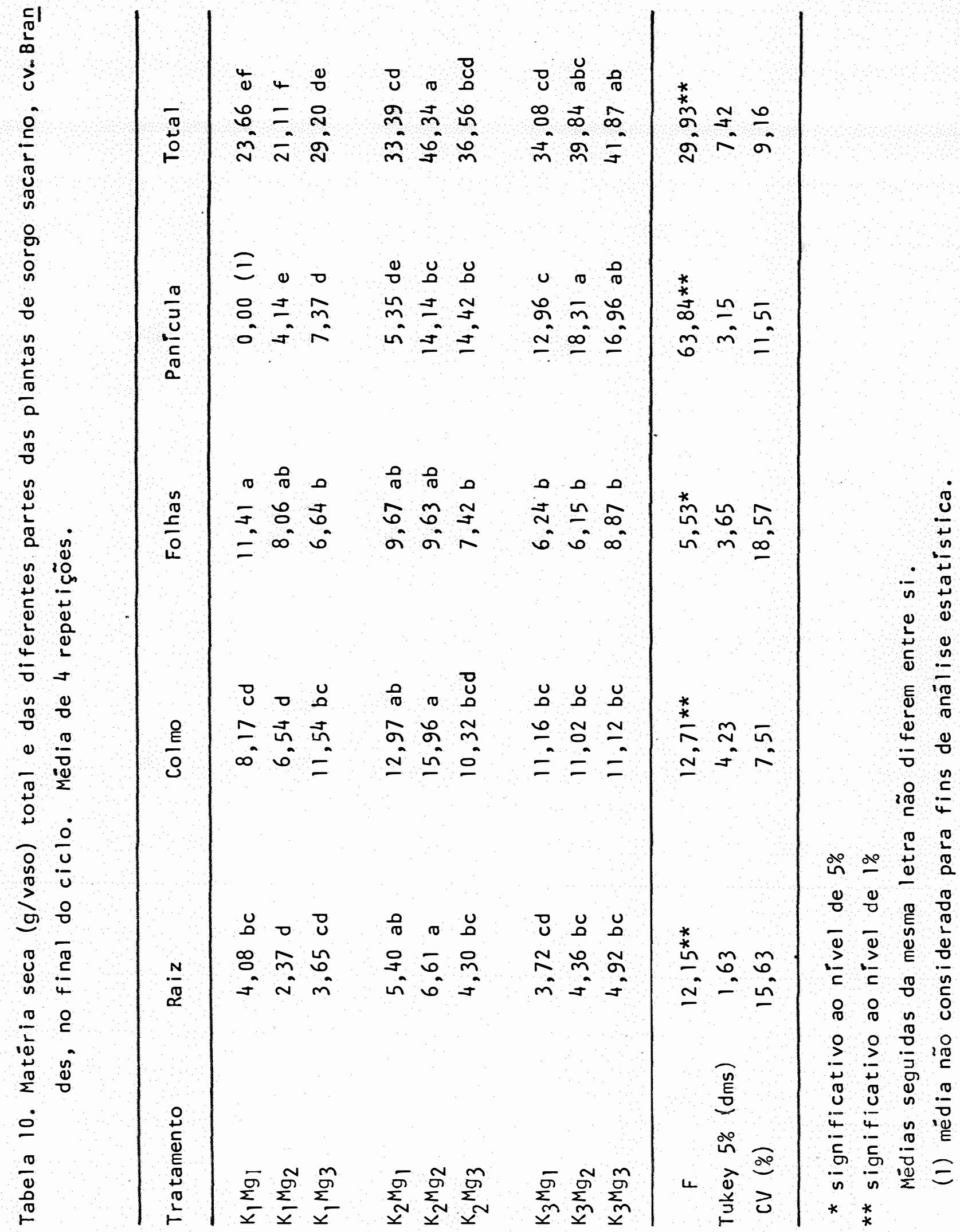


acentuado quando o Mg esteve associado ao nível inferior de potàssio $\left(k_{1}\right)$.

A maior produção de matéria seca de colmos se deu no tratamento $\mathrm{K}_{2} \mathrm{Mg}_{2}$, no qual ambos os elementos $\mathrm{K}$ e $\mathrm{Mg}$ encontram-se diluídos 5 vezes em relação à mäxima concentração e em seguida no tratamento $K_{2} M_{l}$. As relações $\mathrm{K} / \mathrm{Mg} \mathrm{na}$ so lução nutritiva e na folha associadas a māxima produção de colmos foram, respectivamente, de 3,0 e 2,0 .

o desenvolvimento das plantas foi prejudicado, devido a sensibilidade desta cultura ao fotoperiodismo (QUIM BY, 1967; HIPP et alii, 1970).

4.2.3. Diagnose Foliar

os teores médios obtidos para os macronutrien tes K, Ca e Mg encontram-se na Tabela ll. Verifica-se median te a comparação de médias pelo teste de Tukey a $5 \%$, teores de K crescentes à medida que se aumentou a concentração de $K$ na solução nutritiva, enquanto que os teores de Ca demonstraram comportamento inverso; a diminuição de K na solução favoreceu o acúmulo do elemento Ca nas folhas.

Quanto ao magnésio, nos tratamentos com nível mäximo de K, ocorreu tendência para decrēscimo no acūmulo des se elemento; apresentaram por isso maior relação $\mathrm{K} / \mathrm{Mg}$ e $\mathrm{K} / \mathrm{Ca}$ + Mg nas folthas. 
Tabela 11. Teores percentuais de K, Ca e Mg nas folhas medianas $(+3$ e +4$)$ de sorgo sacarino, cv. Brandes, utilizadas para a diagnose foliar aos 40 dias do trans plante.

\begin{tabular}{|c|c|c|c|}
\hline Tratamentos & $K$ & $\mathrm{Ca}$ & $\mathrm{Mg}$ \\
\hline $\mathrm{K}_{1} \mathrm{Mg} 1$ & $0,32 \mathrm{~d}$ & $2,78 a$ & $1,31 a$ \\
\hline $\mathrm{K}_{1} \mathrm{Mg}_{2}$ & $0,87 \mathrm{~cd}$ & $1,72 a b$ & $0,84 \mathrm{bc}$ \\
\hline $\mathrm{K}_{1} \mathrm{Mg}_{3}$ & $0,87 \mathrm{~cd}$ & 1,90 ab & $0,99 \mathrm{bc}$ \\
\hline $\mathrm{K}_{2} \mathrm{Mg}_{1}$ & $1,71 \mathrm{bc}$ & $1,49 \mathrm{~b}$ & $0,85 \mathrm{bc}$ \\
\hline $\mathrm{K}_{2} \mathrm{Mg}_{2}$ & $2,09 a b$ & $1,38 \mathrm{~b}$ & $0,95 \mathrm{~b}$ \\
\hline $\mathrm{K}_{2} \mathrm{Mg}_{3}$ & $1,84 \mathrm{~b}$ & $1,42 \mathrm{~b}$ & $0,88 \mathrm{bc}$ \\
\hline $\mathrm{K}_{3} \mathrm{Mg}_{1}$ & $2,47 \mathrm{ab}$ & $1,02 \mathrm{~b}$ & $0,68 \mathrm{bc}$ \\
\hline $\mathrm{K}_{3} \mathrm{Mg}_{2}$ & $2,53 \mathrm{ab}$ & $1,18 b$ & $0,62 \mathrm{c}$ \\
\hline $\mathrm{K}_{3} \mathrm{Mg}_{3}$ & 2,66 a & $1,23 b$ & $0,64 \mathrm{bc}$ \\
\hline$F$ & $3,25 \mathrm{~ns}$ & $7,56 * *$ & 12,76 ** \\
\hline Tukey $5 \%(\mathrm{dms})$ & 0,91 & 1,072 & 0,33 \\
\hline CV $(\%)$ & 13,43 & 17,25 & 9,76 \\
\hline
\end{tabular}

** significativo ao nível de $1 \%$

As médias seguidas da mesma letra não diferem entre si 
Tais resultados se explicam em termos de inibi ção competitiva no processo de absorção de cátions (EPSTEIN, 1975; MALAVOLTA, 1980).

\subsubsection{Anälises tecnolögicas}

A cv. Brandes considerada sensível ao fotope riodismo (EMBRAPA, 1978), comportou-se como granifera sob con diçōes de dias curtos, que ocorreram durante o ensaio.

obtiveram-se as leituras do obrix (sölidos solüveis) do caldo através do refratōmetroque se apresentaram com teotes bastante baixos.

o colmo foi desintegrado e extraído o caldo com liquidificador na proporção de $50 \mathrm{~g}$ de colmo/lo0 ml ägua. Os resultados das leituras do OBrix foram os seguintes: $\mathrm{K}_{1} \mathrm{Mg}_{1}=6,6 ; \mathrm{K}_{1} \mathrm{Mg}_{2}=4,2 ; \mathrm{K}_{1} \mathrm{Mg}_{3}=6,6 ; \mathrm{K}_{2} \mathrm{Mg}_{1}=7,2$; $\mathrm{K}_{2} \mathrm{Mg}_{2}=6,0 ; \mathrm{K}_{2} \mathrm{Mg}_{3}=5,4 ; \mathrm{K}_{3} \mathrm{Mg} 1=6,0 ; \mathrm{K}_{3} \mathrm{Mg}_{2}=4,8 \mathrm{e} \mathrm{K} \mathrm{Mg}_{3}=$ 4,5. Tirando-se as médias dos tratamentos com níveis crescen tes de K obtêm-se: $K_{1}=5,8 ; K_{2}=6,2$ e $K_{3}=5,1$, isto sugere um aumento no teor de sölidos totais com a dose intermediä ria de K e diminuição nas extremas. 


\subsection{Efeito das doses de nitrogênio (terceiro experimento).}

\subsubsection{Sintomas}

Aos 30 dias após o tratamento para solução definitica, as plantas submetidas ao tratamento $1: 20,1: 10$ de N apresentavam leve clorose nas folhas mais velhas. $\bar{A}$ medida que os sintomas alcançavam estädios mais avançados, as folhas tornavam-se totalmente cloróticas e as suas pontas e margens necrōticas. Observou-se tambēm que as folhas tomaram um aspecto com estreitamento do limbo foliar.

O sistema radicular foi prejudicado, apresentan do menor crescimento das radicelas e presença de coloração avermelhada. Estes sintomas assemelham com os obtidos por MA LAVOLTA et alii (1979).

o desenvolvimento geral da planta foi menor, sendo notadamente afetado o diàmetro do caule.

\subsubsection{Dados fenolögicos}

- Verifica-se através da Tabela 12, as medições realizadas no diâmetro dos colmos, altura das plantas e matéria fresca de colmos.

Observa-se na Figura 2 que as produções de col mos verdes aumentaram linearmente com as doses de nitrogênio, sendo mäximas na solução completa. Efeitos positivos das do- 
Tabela 12. Matéria fresca, comprimento e diámetro dos colmos das plantas de sorgo sacarino, cultivadas em solução nutritiva com doses de nitrogênio (média de 4 repetições).

\begin{tabular}{lccc}
\hline & Matéria fresca & Comprimento & Diâmetro \\
Doses de N & $(g)$ & $(\mathrm{cm})$ & $(\mathrm{cm})$ \\
\hline $1: 20$ & $68,72 \mathrm{c}$ & $122,25 \mathrm{~b}$ & $1,05 \mathrm{~d}$ \\
$1: 10$ & $106,65 \mathrm{~b}$ & $127,00 \mathrm{~b}$ & $1,17 \mathrm{~cd}$ \\
$1: 5$ & $118,79 \mathrm{~b}$ & $132,00 \mathrm{~b}$ & $1,62 \mathrm{~b}$ \\
$1: 1$ & $474,69 \mathrm{a}$ & $227,50 \mathrm{a}$ & $2,17 \mathrm{a}$ \\
\hline & & & $24,05 * *$ \\
F & $553,68 * *$ & $48,59 * *$ & 0,43 \\
Tukey $5 \%$ (dms) & 33,83 & 30,34 & 13,72 \\
C. V. $(\%)$ & 8,38 & 9,49 & \\
& & & \\
\hline
\end{tabular}

** significativo ao nivel de $1 \%$

As médias seguidas da mesma letra não diferem entre si.

ses de $N$ sobre a produção de colmos verdes foram obtidos por ROSOLEM (1979), RODRIGUES (1981), TEDRUS (1982), ROSOLEM e t ali $\mathrm{i}(1981)$, CORDEIRO et ali $(1982)$, COUTINHO (1983), SILVA $(1983)$

Na solução completa, as alturas das plantas fo ram superiores aos demais tratamentos e os diàmetros do colmo decresceram com a diminuição de $N$ na solução. 
47.

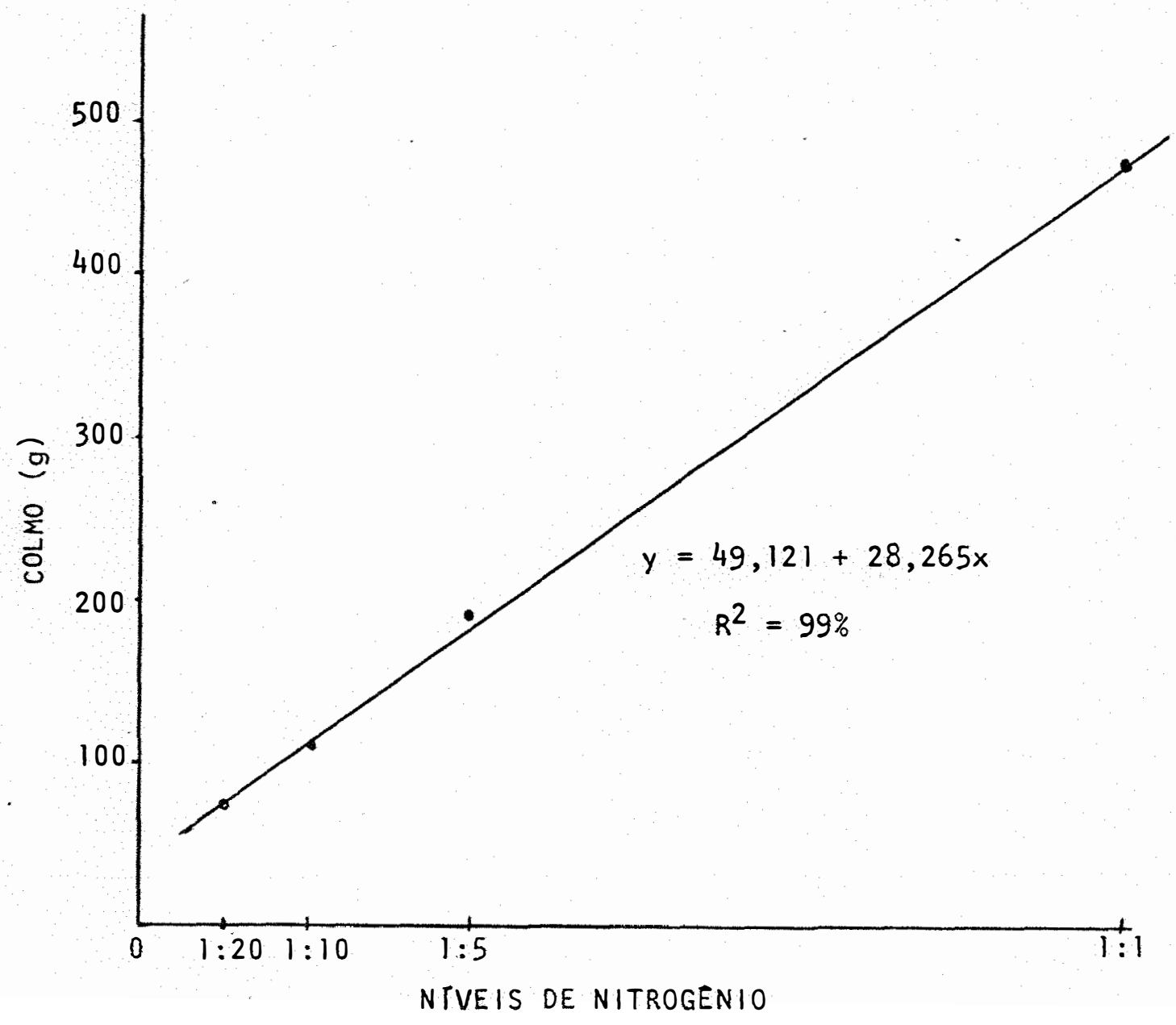

Figura 2. Relação entre dose de $N$ e grama de matéria fresca de colmo. 
Entretanto ROSOLEM (1979), RODRIGUES

e ZANINI (1982) trabalhando com a mesma cultivar em condições de campo não constataram diferenças estatisticamente significativas para esses dois parâmetros em função das doses de N.

4.3.3. Produção de matēria seca

Os dados referentes a produção de matéria seca encontram-se na Tabela 13.

A parte da planta mais afetada em função da di luif̧ão do N na solução foi o colmo. Houve redução de aproximadamente $600 \%$ para a dose menor de $N(1: 20)$ e redução de $375 \%$ e $330 \%$ para os niveis de $1: 10$ e $1: 5$ de $N$, respectivamente, em relação à dose máxima $(1: 1)$.

Para o peso da panicula a redução foi de $490 \%$, $286 \%$ e $280 \%$ para os tratamentos $1: 20$ e $1: 10$ e $1: 5$ de $\mathrm{N}$, respectivamente, em relação ao tratamento completo.

Para o peso total a redução foi de $506 \%, 321 \%$ e $283 \%$ para os tratamentos $1: 20,1: 10$ e $1: 5$ de N respectivamente em relação ao tratamento completo.

ROSOLEM (1979), obteve com esta cultivar em so 1 ução nutritiva uma redução de $300 \%$ no peso de matēria seca de colmo, $320 \%$ no peso dos grãos, $230 \%$ no peso total da planta quando submetida a uma diluição de dez vezes em relação ao completo. 
Tabela 13. Matéria seca (g/vaso) total e das partes das plantas de sorgo sacarino, cultivadas em solução nutri tivas com doses de nitrogênio (mëdia de 4 repetiçoes).

\begin{tabular}{|c|c|c|c|c|c|}
\hline Doses de $N$ & Raiz & Colmo & Folhas & $\begin{array}{l}\text { Raquet } \\
\text { grãos }\end{array}$ & Total \\
\hline $1: 20$ & $8,61 \mathrm{c}$ & $15,73 \mathrm{c}$ & $7,04 \mathrm{c}$ & $6,12 b$ & $37,53 \mathrm{c}$ \\
\hline $1: 10$ & $12,81 \mathrm{bc}$ & $24,94 \mathrm{bc}$ & $10,85 \mathrm{~b}$ & $10,49 b$ & $59,08 \mathrm{~b}$ \\
\hline $1: 5$ & $14,57 \mathrm{~b}$ & $28,41 \mathrm{~b}$ & $13,50 \mathrm{~b}$ & $10,71 b$ & $67,19 \mathrm{~b}$ \\
\hline $1: 1$ & 33,79 a & 93,69 a & 32,68 a & $30,01 \quad a$ & $190,17 a$ \\
\hline$F$ & $75,13 * *$ & $184,71 * *$ & $203,64 * *$ & $58,87 * *$ & $269,49 * *$ \\
\hline Tukey $5 \%$ (dms) & 5,42 & 11,04 & 3,36 & 5,85 & 17,64 \\
\hline C.V. (\%) & 14,78 & 12,92 & 9,99 & 19,41 & 9,49 \\
\hline
\end{tabular}

** significativo ao nivel de $1 \%$

Mëdias seguidas da mesma letra não diferem entre si.

Verificou-se que a produção de colmos das plantas submetidas a tratamento completo foi estatisticamente superior as demais. Os tratamentos com niveis $1: 5$ e $1: 10$ de $\mathrm{N}$ na solução não diferiram entre si, porēm o nível 1:5 diferiu do nível baixo $(1: 20)$. No caso da produção de grãos, apenas o nível mäximo se destacou entre os demais. Quanto à acumulação de matéria seca total comportou-se de modo semelhante ao colmo. 
50.

\subsubsection{Diagnose foliar}

Na Tabela 14 encontram-se as concentrações de macronutrientes encontrados nas folhas medianas do sorgo saca rino coletadas em 2 épocas de amostragem, aos 45 dias e aos 78 dias apös o transplante.

Quando se correlacionou as doses de $N$ na solução com os teores foliares de nitrogênio, constatou-se que $97 \%$ da variação foi explicada pela equação de regressão polinomial do 10 grau. A maior concentração de nitrogênio foi encontrada no tratamento completo, conforme se pode observar na figura 5 .

Encontram-se na literatura os dados da diagnose foliar obtidos por ROSOLEM (1979) com a cultivar Brandes; tais dados estão bastante pröximos dos encontrados no presente ensaio quando consideradas as plantas submetidas ao tratamento com a mesma concentração do nutriente.

Para possibilitar a comparação dos desequilibrios nutricionais nas 2 épocas de amostragem, foi realizada representação gräfica através das figuras hexagonais (figu ra 3); segundo MALAVOLTA $(1980)$, dos diferentes niveis de nitrogênio, nas duas ēpocas de amostragens.

A figura do hexāgono equilàtero indica os teores encontrados nas folhas das plantas do tratamento completo, istoè, com o nível l:l de nitrogênio. A figura se modifica quando a composição da folha corresponde a um desequilí brio nutricional. 
51.

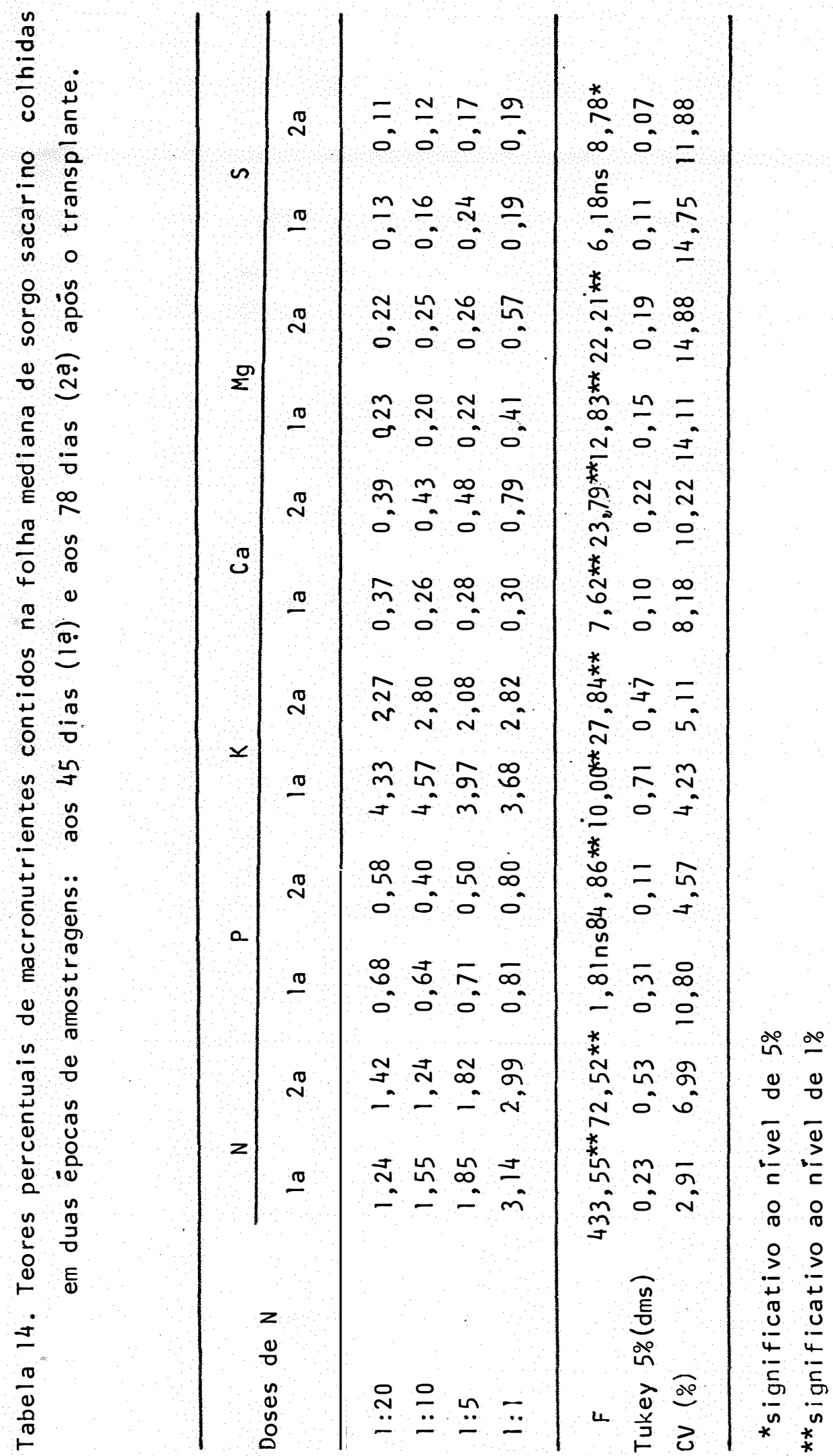



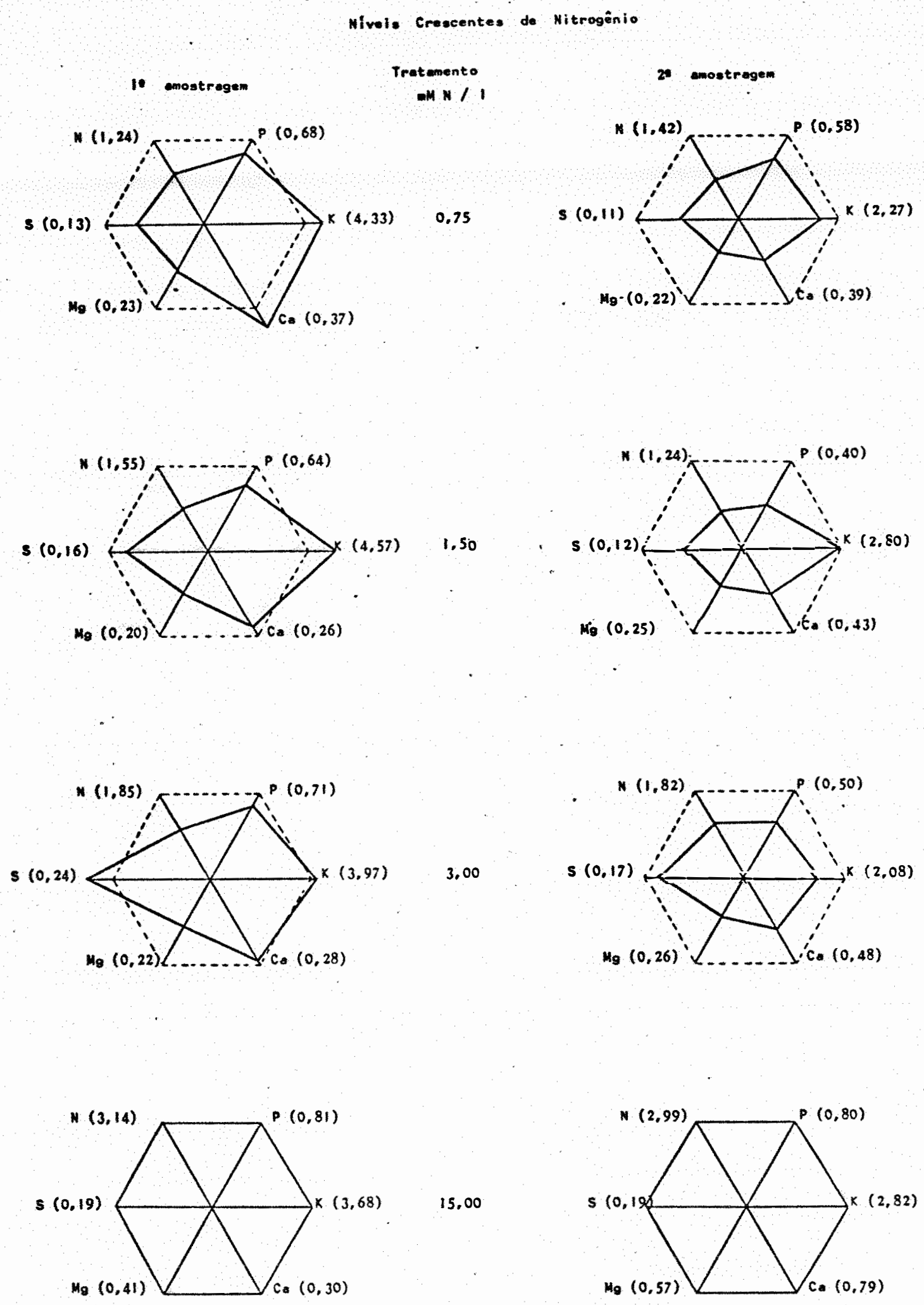

Figura 3. Representação hexagonal dos teores $(\%)$ de macronutrientes encontrados nas folhas medianas de sorgo sacarino cultivado em so luçäo nutritiva com doses de $N$, aos 45 e 78 dias apōs o trans plante. 
SUMNER (1978) E MALAVOLTA (1980), discutem como as interaçōes podem se refletir no teor foliar dos elementos, o que deve ser considerado na interpretação dos dados de diagnose foliar.

$\mathrm{Na}$ la amostragem verificou-se em todos os niveis inferiores de $\mathrm{N}$, menor absorção de $\mathrm{P}$ e $M g$ e um leve aumento na absorção de $K$. A interação entre $N$ e $K$ é conhecida em trabalhos experimentais (DECHEVA et alii, 1970).

Na 2 a amostragem a redução no suprimento do $N$ causou decréscimo na absorção de todos os outros elementos.

Estudando o efeito da relação N/P, EPPENDORFER (1971), relata que altas aplicações de $N$ em relação ao P, pro voca uma maior absorção do primeiro pelas plantas em relação ao $P$, sendo o inverso também verdadeiro, concluindo que os nu trientes relacionam-se nos dois sentidos.

A maior produção de colmo se deu quando as re lações N/P e N/S apresentaram valores altos 4,0 e 16,5 , respectivamente, na la e 2 a épocas de amostragem (Tabela 15). Ve rificou-se, entretanto, do ponto de vista da avaliação do estado nutricional, que a variação sofrida pelo teor foliar de $N$ em função dos tratamentos, foi, em termos percentuais, maior que a verificada nas relações N/P e N/S.

Neste ensaio, as premissas da diagnose foliar foram satisfeitas em ambas as épocas de amostragem, tanto para a produção de colmo, quando para a produção de grãos. 0 nivel critico fisiolögico correspondente a uma produção rela- 
Tabela 15. Relaçöes N/P e N/S obtidas atravēs das concentrações das folhas medianas de sorgo sacarino colhidas em duas épocas de amostragens: aos 45 dias (1a) e 78 dias (2a) apös o transplante.

\begin{tabular}{llllll}
\hline Doses de N & 1a A N & 29 A & 1a A. & 2a A. \\
\hline $1: 20$ & 1,82 & 2,44 & 9,54 & 12,91 \\
$1: 10$ & 2,42 & 3.10 & 9,68 & 10,33 \\
$1: 5$ & 2,60 & 3,64 & 7,71 & 10,70 \\
$1: 1$ & 3,87 & 3,74 & 16,53 & 15,74 \\
\hline
\end{tabular}

tiva de colmo igual a $90 \%$ deve estar em torno de $3,0 \%$ de $\mathrm{N}$. (Observar figuras 4,5 e 6 ).

\subsubsection{Anälise tecnolögica}

Encontram-se na Tabela 16 os resultados obtidos para OBrix no sorgo, Pol no sorgo, \%fibra no sorgo, \% Açücares Totais no caldo extraído, \% Açücares redutores no caldo extraído e \% Caldo Absoluto no colmo com doses de $N$.

Observa-se uma tendência de aumento de açūcares totais, embora ocorra, na dose mais elevada, uma diminuição dos mesmos. Mediante a utilização da anālise de regressão foram obtidas as equações relacionando os teores de açūcares to tais e açücares redutores $(y)$ com as doses de $N(x)$ : 
Niveis Crescentes de Nitrogênio

55.

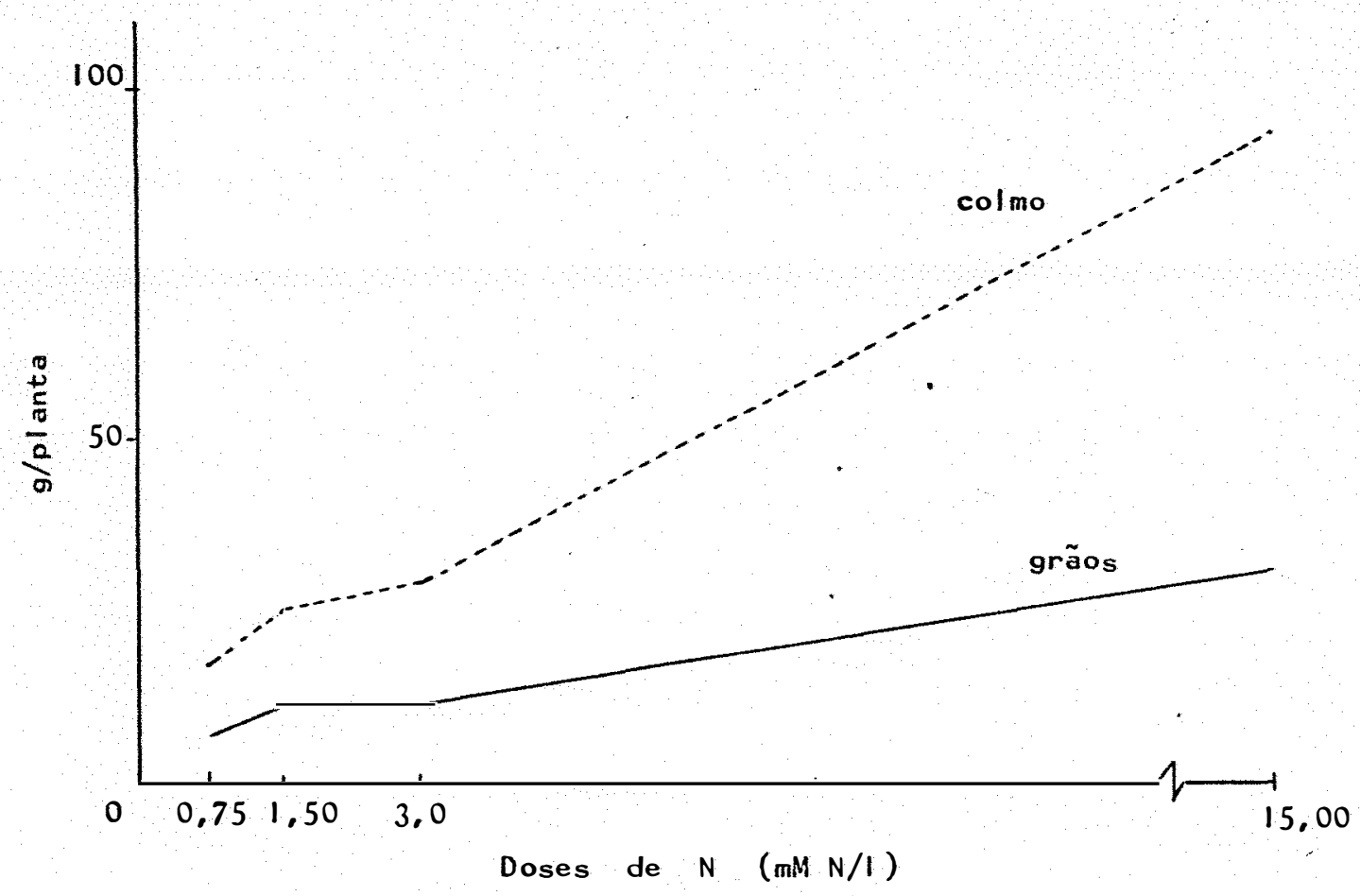

Figura 4. Relação entre dose e produção de colmo e grão.

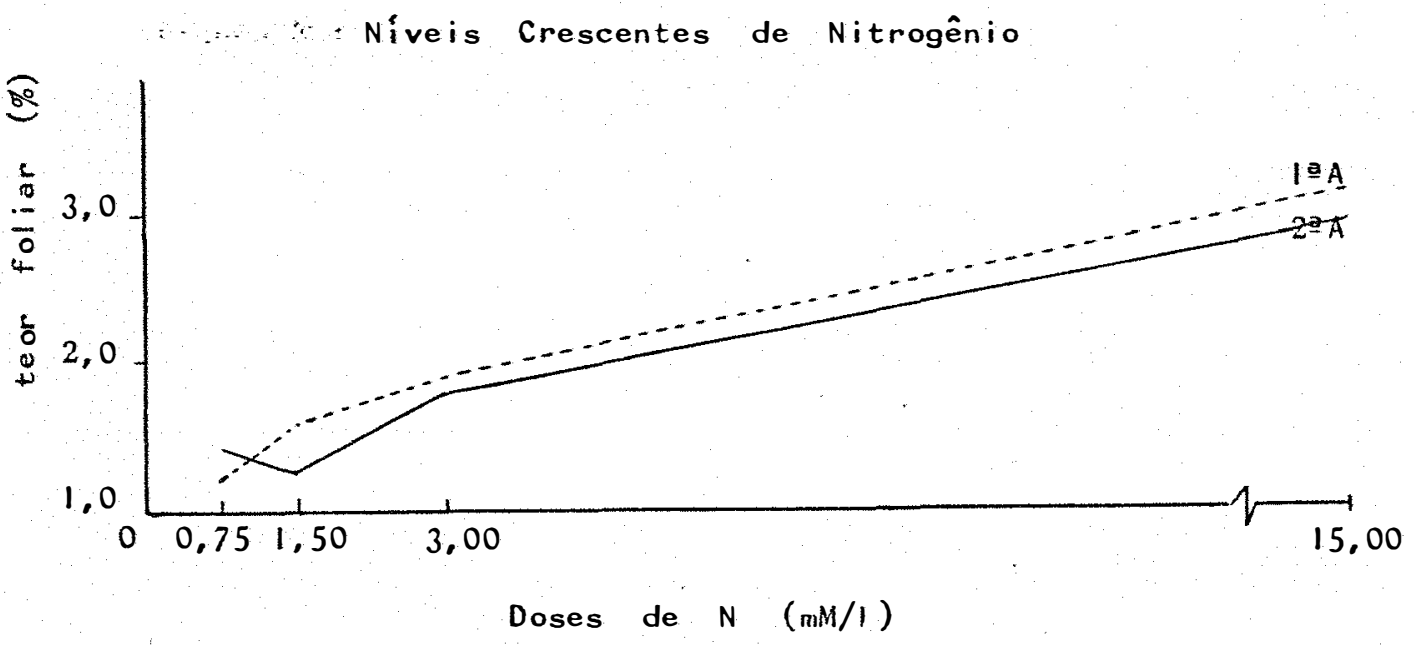

Figura 5. Relação entre dose e teor foliar. 


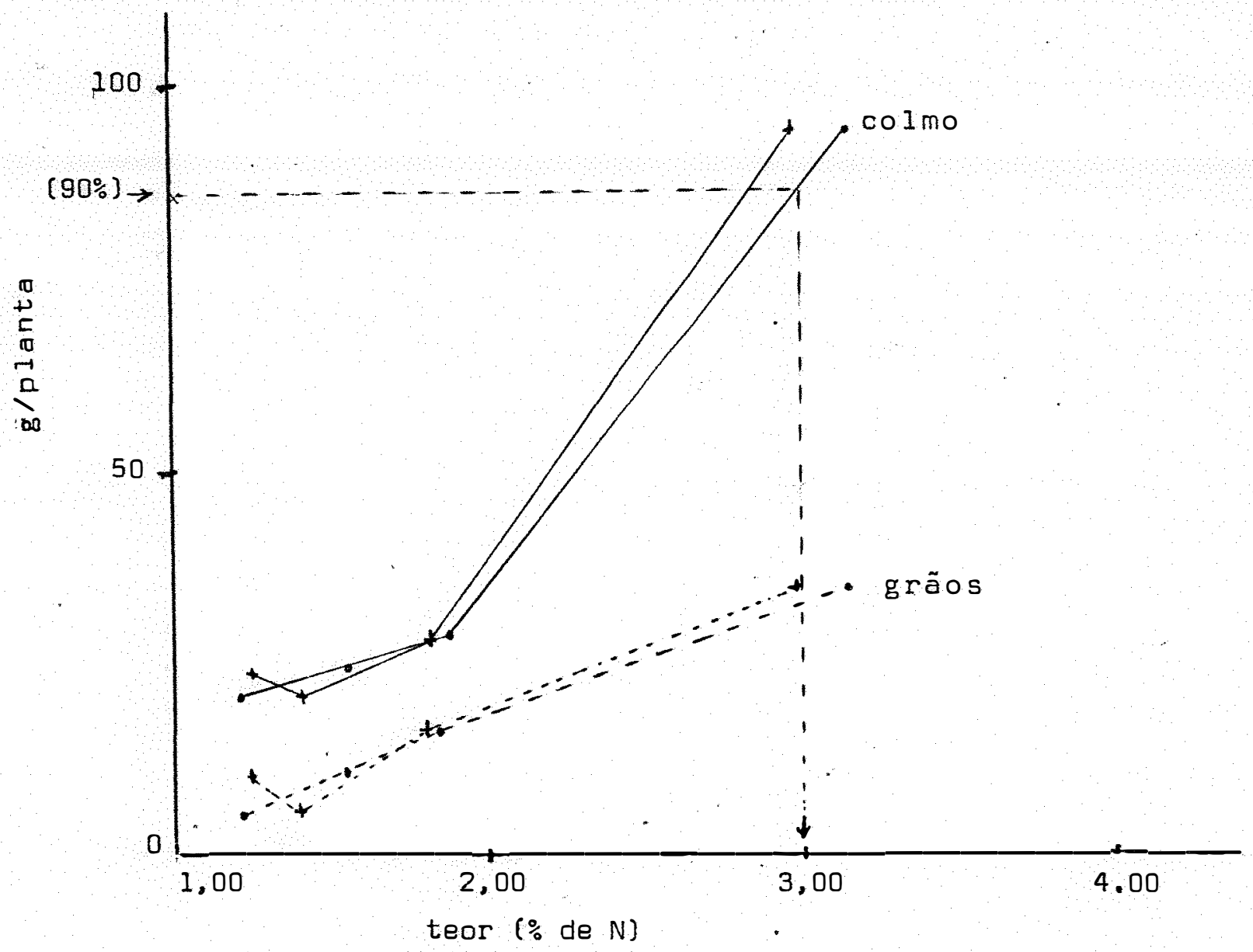

Figura 6. Rêlação entre teor e produção de colmo e grãos.

(1) ART $-y=6,5746+0,81266 x-0,061736 x^{2}$

(2) $A R-y=0,8241+0,109794 x$

os valores de $R^{2}$ foram, respectivamente 76 e $82 \%$.

Na l i teratura hä evidências de que o aumento na quantidade de nitrogênio aplicada causa efeito decrescente na porcentagem de sacarose e produção de açūcar no colmo (RI CAUD, 1971). Isto pode ser explicado levando-se em conta a 
Tabela 16. Análises dos componentes tecnológicos do sorgo sacarino, cultivado em solução nutritiva com doses de nitrogênio.

\begin{tabular}{|c|c|c|c|c|}
\hline \multirow{2}{*}{ Componentes } & \multicolumn{4}{|c|}{ Doses de $N$} \\
\hline & $1: 20$ & $1: 10$ & $1: 5$ & $1: 1$ \\
\hline Peso do caldo\% & 42,00 & 50,96 & 49,44 & 64,69 \\
\hline Caldo absoluto \% sorgo & 88,69 & 89,67 & 89,71 & 92,39 \\
\hline Brix sorgo & 9,13 & 11,20 & 10,83 & 9,60 \\
\hline Pol sorgo & 5,21 & 7,54 & 6,12 & 3,38 \\
\hline Fibra \% sorgo & 11,31 & 10,33 & 10,28 & 7,60 \\
\hline Açūcares totais \% CE & 6,61 & 8,67 & 8,29 & 5,78 \\
\hline Açücares redutores \% CE & 0,54 & 0,97 & 1,61 & 2,40 \\
\hline
\end{tabular}

interação N/K frequentemente observada. DECHEVA et alii, 1970 observaram redução na absorção de K em plantas submeti das a doses crescentes de $N$.

Plantas com excesso de $N$ apresentam teor mais baixo de açūcar em relação às plantas que receberam a dose me nor. Ao que parece, esse efeito prejudicial só ocorre quando - excesso de $N$ produz atraso na maturação (MALAVoLTA et alii, $1974)$.

Os valores de ${ }^{\circ}$ Brix e Pol näo tiveram variações significativas pelas regressões e o seu coeficiente de correlação foram de $36 \%$ e $62 \%$ respectivamente. 
SERRA (1979), apresenta dados médios dos compo nentes tecnológicos de três variedades de sorgo sacarino (Bran des, Dale e Riol: 370 a $640 \mathrm{~kg}$ de caldo/t; 15 a $21 \%{ }^{\circ}$ Brix; 13 a $20 \%$ açücares totais; 1,5 a $9,0 \%$ açücares redutores e 8,0 a $17,5 \%$ de sacarose.

Comparando-se esses dados com os da Tabela 16 observa-se que todas as caracteristicas tecnolögicas estão com valor abaixo do mínimo obtido por esse autor, com exceção do peso do caldo. Tomando-se o peso do caldo, estimou-se a quantidade de caldo (em $\mathrm{kg}$ ) por tonelada do colmo, obtendo-se os dados apresentados na Tabela 17.

Tabela 17. Estimativa do rendimento em àlcool etilico de sorgo sacarino cultivado em solução nutritiva com doses de nitrogênio.

Doses de nitrogênio

Rendimento

$\begin{array}{llll}1: 20 & 1: 10 & 1: 5 & 1: 1\end{array}$

$\mathrm{kg} \mathrm{caldo/t}$ colmo

420

509

494

647

$\mathrm{kg}$ caldo/ha

14700

17815

17290

22645

kg açücares totais/ha

971

1544

1433

1309

la álcool/t

15

24

23

21

l àlcool/ha

539

856

795

725 
Avaliou-se o rendimento em àlcool por ha de sorgo sacarino nos tratamentos analisados. Os resultados são apresentados na Tabela 17.

Comparando-se esses resultados com os estimados por SERRA (1979) e SILVA (1983), observa-se que os mesmos estão bem abaixo dos valores estabelecidos. A causa principal dessa diferença se deve ao baixo teor de açücares totais avaliados no presente experimento.

4.4. Efeito de doses de fösforo

4.4.1. Sintomas

O aparecimento de sintomas de carência de fósforo teve início aproximadamente 20 dias após o transplante pa as soluções definitivas (tratamentos).

As folhas mais velhas apresentavam uma coloração verde pouco mais escura que a planta não deficiente; com - decorrer do tempo começaram a aparecer manchas comaspecto de queima das, esbranquiçadas nas margens da folha.

Houve manifestações de sintomas típicos em algumas folhas mais velhas que iniciavam com uma clorose marginal que progredia no sentido da nervura principal e mais tar de tornavam-se necröticas e secavam.

Estes sintomas apareceram nos tratamentos de niveis $1: 20,1: 10$ e $1: 5$ de $P$. 
A descrição concorda com os verificados por MA LAVOLTA et ali i. (1979).

\subsubsection{Dados fenológicos}

Na Tabela 18 encontram-se os dados de matēria fresca, comprimento e diâmetro do colmo.

Tabela 18. Matēria fresca, comprimento e diámetro do colmodas plantas de sorgo sacarino, cultivadas em solução nú tritiva com doses de fósforo (média de 4 repetiçöes ).

\begin{tabular}{|c|c|c|c|}
\hline Doses de $P$ & $\begin{array}{c}\text { Matéria fresca } \\
\text { (g) }\end{array}$ & $\begin{array}{l}\text { Comprimento } \\
\text { (cm) }\end{array}$ & $\begin{array}{l}\text { Diâmetro } \\
\text { (cm) }\end{array}$ \\
\hline $1: 20$ & $109,35 d$ & $139,00 \mathrm{~d}$ & $1,20 \mathrm{~b}$ \\
\hline $1: 10$ & $233,56 c$ & $171,50 \mathrm{bc}$ & $1,87 a$ \\
\hline $1: 5$ & $280,64 \mathrm{~b}$ & $186,75 a b$ & $2,15 a$ \\
\hline $1: 1$ & 379,10 a & 199,75 a & 2,35 a \\
\hline$F$ & $111,45^{* *}$ & $15,63^{* *}$ & $17,61 * *$ \\
\hline Tukey 5\% (dms) & 44,59 & 27,81 & 0,49 \\
\hline C.V. $(\%)$ & 8,47 & 7,59 & 12,29 \\
\hline
\end{tabular}

** significativo ao nivel de $1 \%$

As médias seguidas da mesma letra não diferem entre si.

As comparações de níveis realizadas pelo teste de Tukey $5 \%$ obedeceu as diluições do elemento $P$ das soluções nutritivas. 
Para a altura das plantas e diâmetros, as diferenças foram significativas quando comparou-se plantas da solução completa e de diluição $1: 20$.

Segundo MALAVOLTA et alii (1974) a deficiência de $P$ em cana-de-açūcar causa redução no diâmetro e no comprí mento dos colmos e internódios mais curtos; isto foi verifica do nos tratamentos com menor nível de $P$.

No experimento em campo realizado por ROSOLEM (1979) as diferenças em função dos niveis de adubăção fosfatada para essas características fenológicas não foram signifi cativas.

4.4.3. Produção de matēria seca

As produções de matéria seca total e por partes da planta submetida a tratamento com niveis crescentes de P encontram-se na Tabela 19.

Nota-se que o nível mais baixo de $p$ apresentou redução no acūmulo de matéria seca de raízes, bem como de colmos, e nos demais tratamentos não diferiram nestas partes da planta.

A produção de panícula foi superior para os tratamentos com niveis $1: 5$ e $1: 1$ de $P$.

4.4.4. Diagnose foliar

Constam na Tabela 20 os teores de macronutrientes das folhas analisadas. 


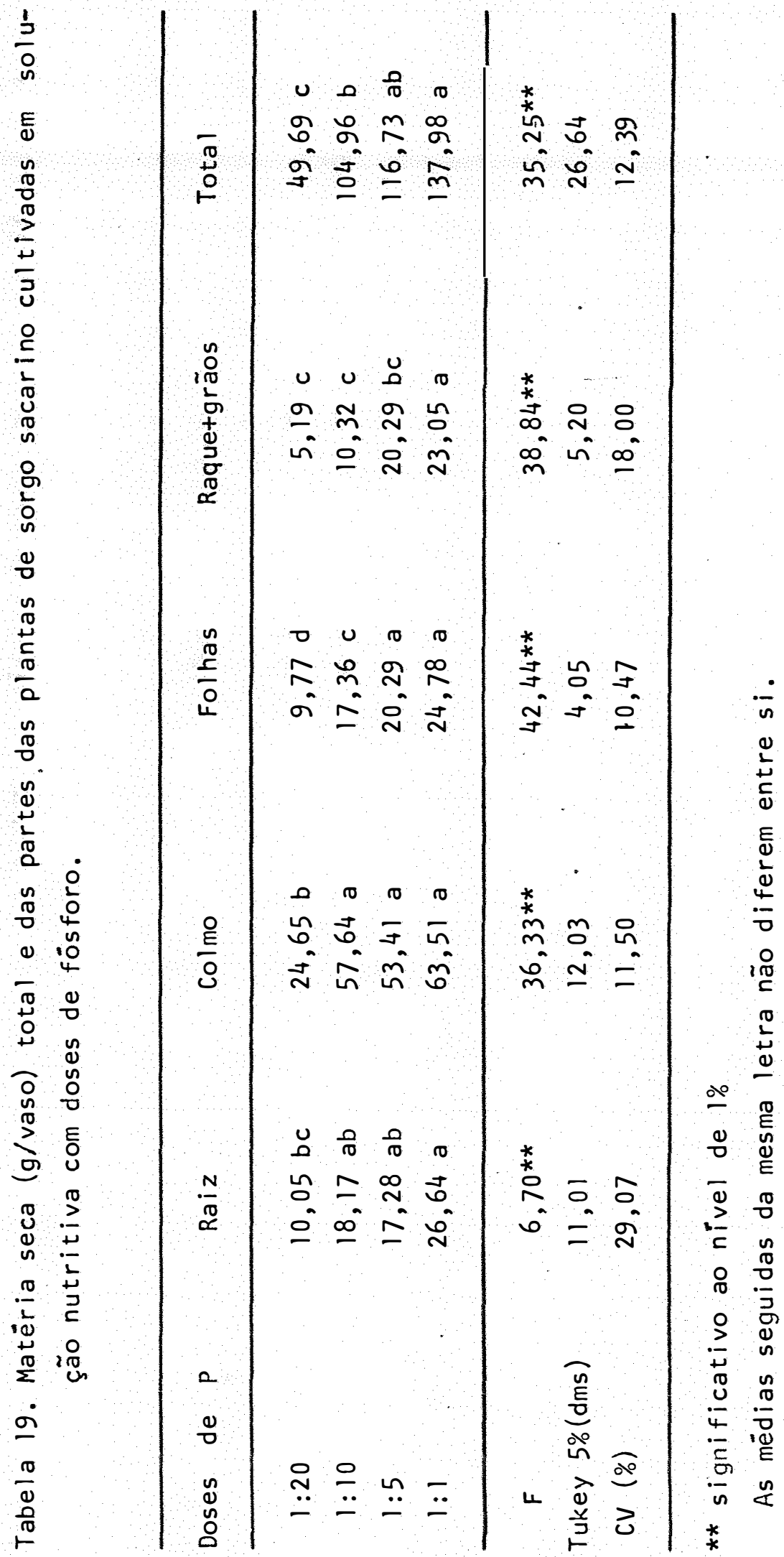


63.

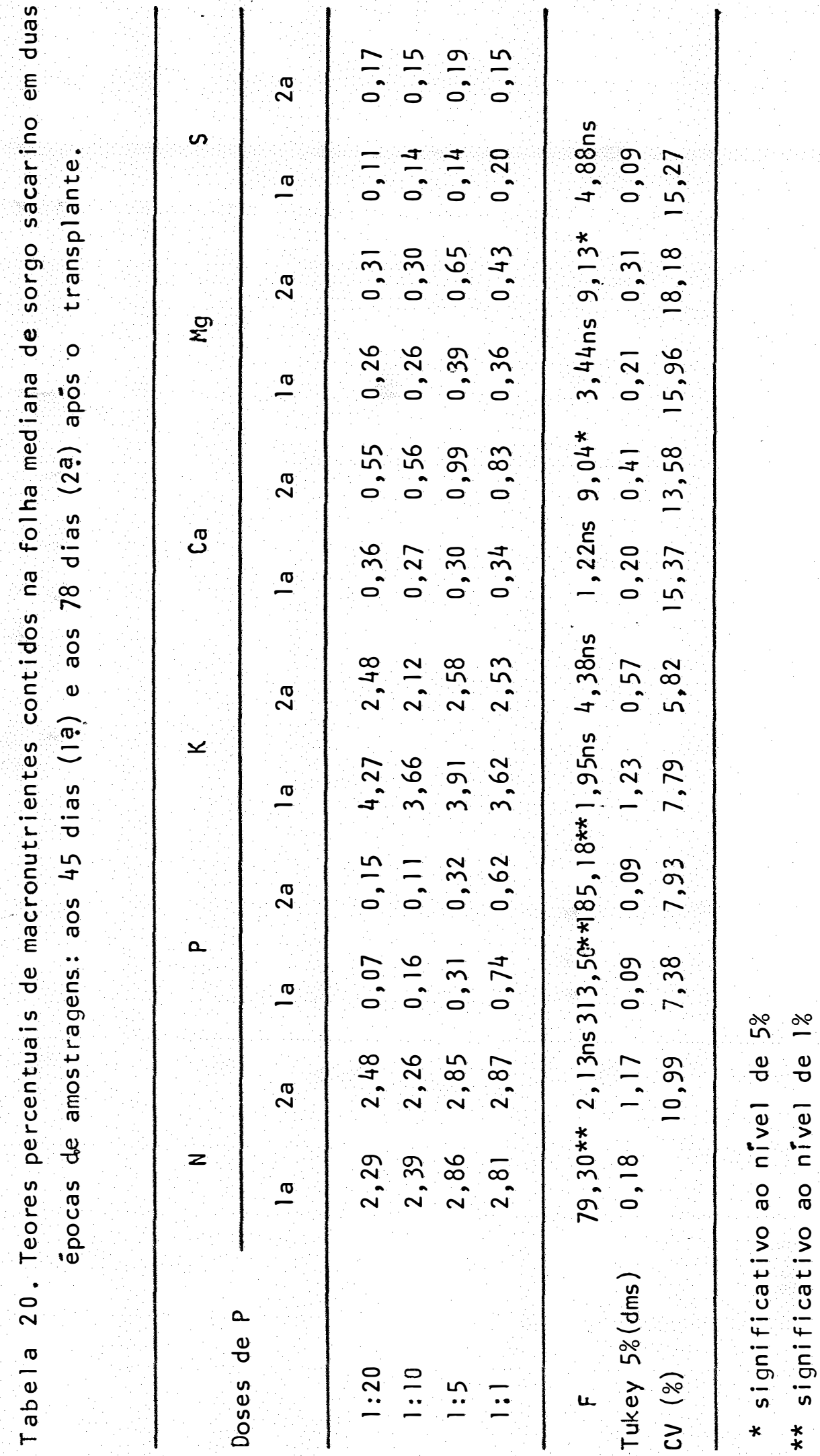


0 teor de P cresce com a dosagem do mesmo fornecida na solução, embora sem diferenças significativas para os tratamentos $1: 20$ e $1: 10$ de $P$ nas duas épocas de amostragem.

Pode-se visualizar os desequilibrios nutricio nais devido à variação nos níveis de fósforo no meio, atravēs de representações dos hexägonos na Figura 7 .

Os teores encontrados para o tratamento comple to são concordantes com os obtidos por ROSOLEM (1979).

Para os elementos $\mathrm{N}, \mathrm{Ca}$ e $\mathrm{Mg}$, houve diferenças significativas nos teores, somente na 2 a amostragem, sendo superiores nos níveis $1: 5$ e $1: 1$ de $p$ na solução; os demais tra tamentos não apresentaram diminuição ou aumento sensível dos teores dos elementos.

Encontram-se na Tabela 21 as relações N/P das folhas para as diferentes doses de $P$ na solução.

A variação apresentada em termos percentuais no teor de $\mathrm{P}$ foi maior que a sofrida pela relação N/P em função dos tratamentos. Conclui-se, pois, que o teor de fósforo representou indicação adequada do estado nutricional.

0 exame das Figuras 8,9 e 10 , mostra que as premissas da diagnose foliar são observadas em ambas as épocas de amostragem, para produção de grãos e colmos.

o nivel crítico fisiológico correspondente a uma produção de colmo igual a $90 \%$, obtida através de interpolação gräfica esteve em torno de $0,16 \%$ de P. Este valor $\vec{e}$ 
Tabela 21. Relação N/P obtidas atravēs das concentrações de $N$ e $P$ nas folhas medianas de sorgo sacarino colhidas em duas épocas de amostragens: aos 45 dias (1a) e aos 78 dias (2:) após o transplante.

\begin{tabular}{lcc}
\hline Doses de $P$ & Primeira & Segunda \\
\hline $1: 20$ & 32,71 & 16,53 \\
$1: 10$ & 14,93 & 20,54 \\
$1: 5$ & 9,22 & 8,90 \\
$1: 1$ & 3,79 & 4,62 \\
\hline
\end{tabular}

muito menor que o encontrado por ROSOLEM (1979) em condições semelhantes.

4.4.5. Anālise tecnolögica

Encontram-se na Tabela 22 , os resultados médios das características tecnolögicas obtidas nos colmos de sorgo em função das doses de $P$.

Na Tabela 23 encontram-se as estimativas dos rendimentos de àlcool etílico. 


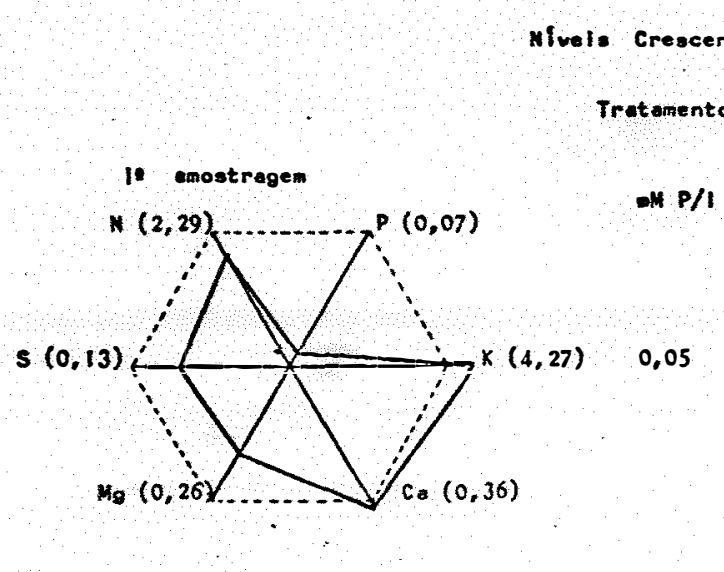

fósforo

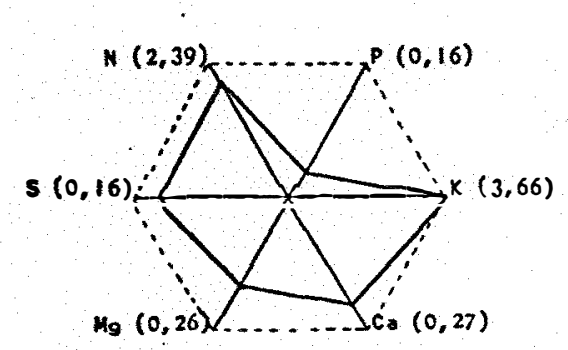

0,10

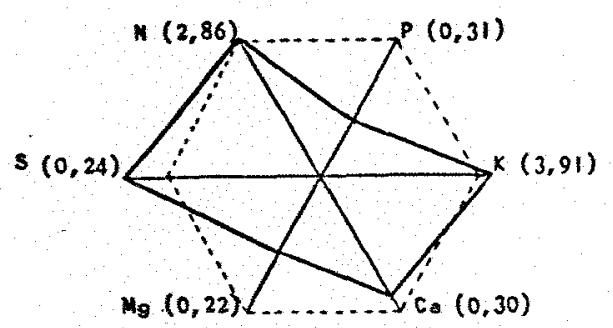

0,20
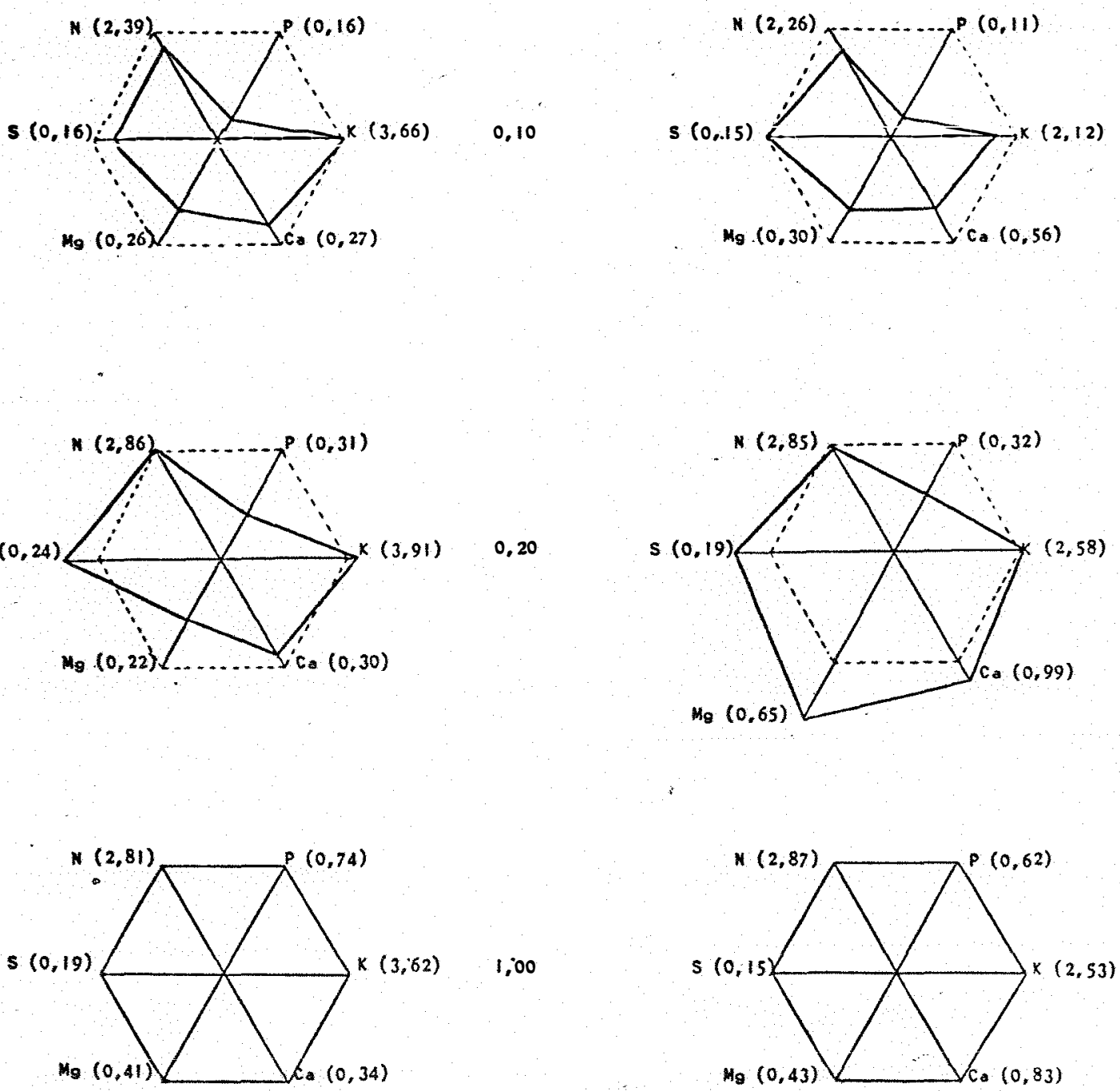

Figura 7. Representação hexagonal dos teores (\%) de macronutrientes encon trados nas folhas medianas de sorgo sacarino cultivado em solução nutritiva com doses de $P$, aos 45 e 78 dias após o transplante. 


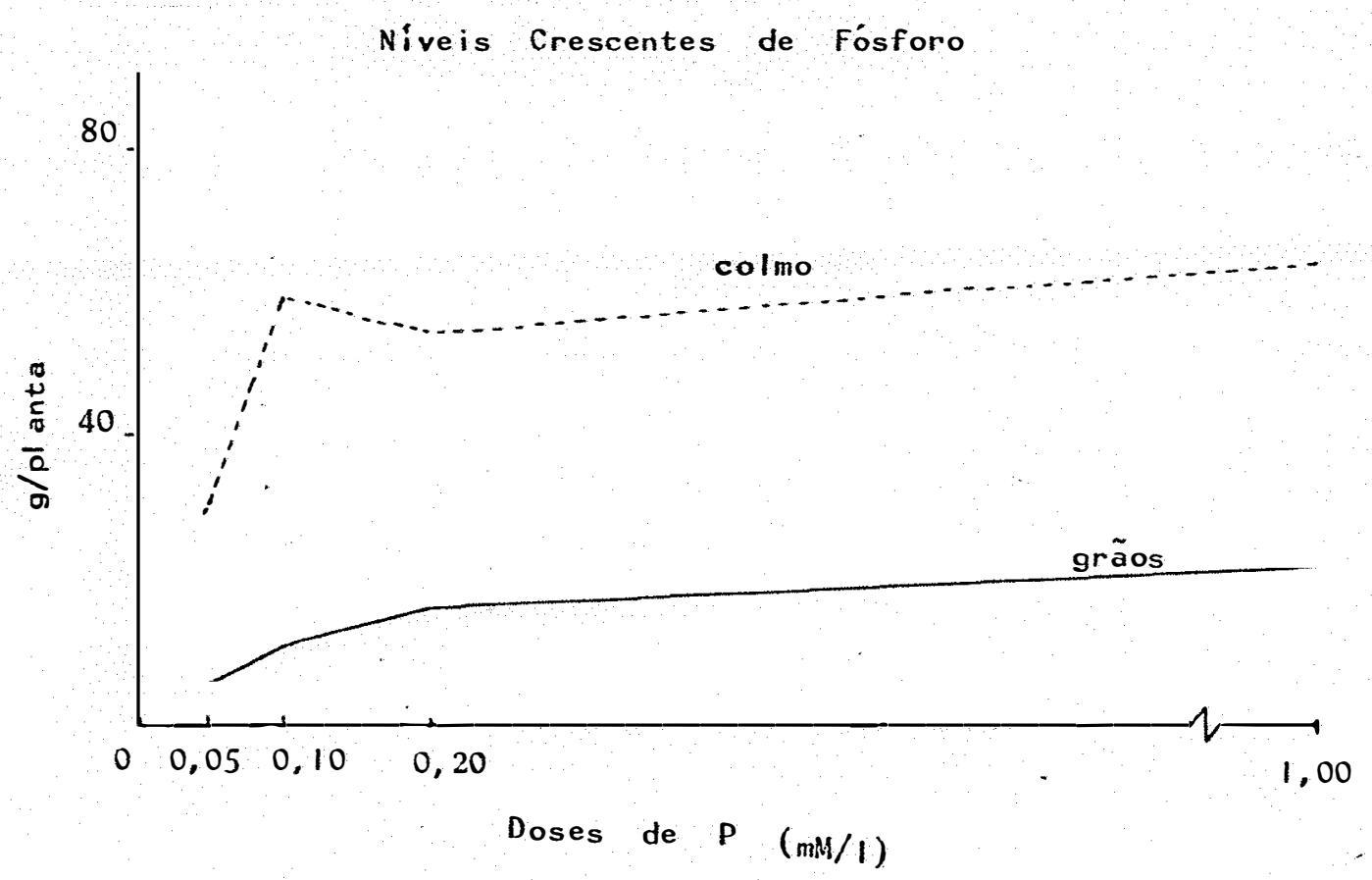

Figura 8. Relação entre dose e produção de colmo seco.

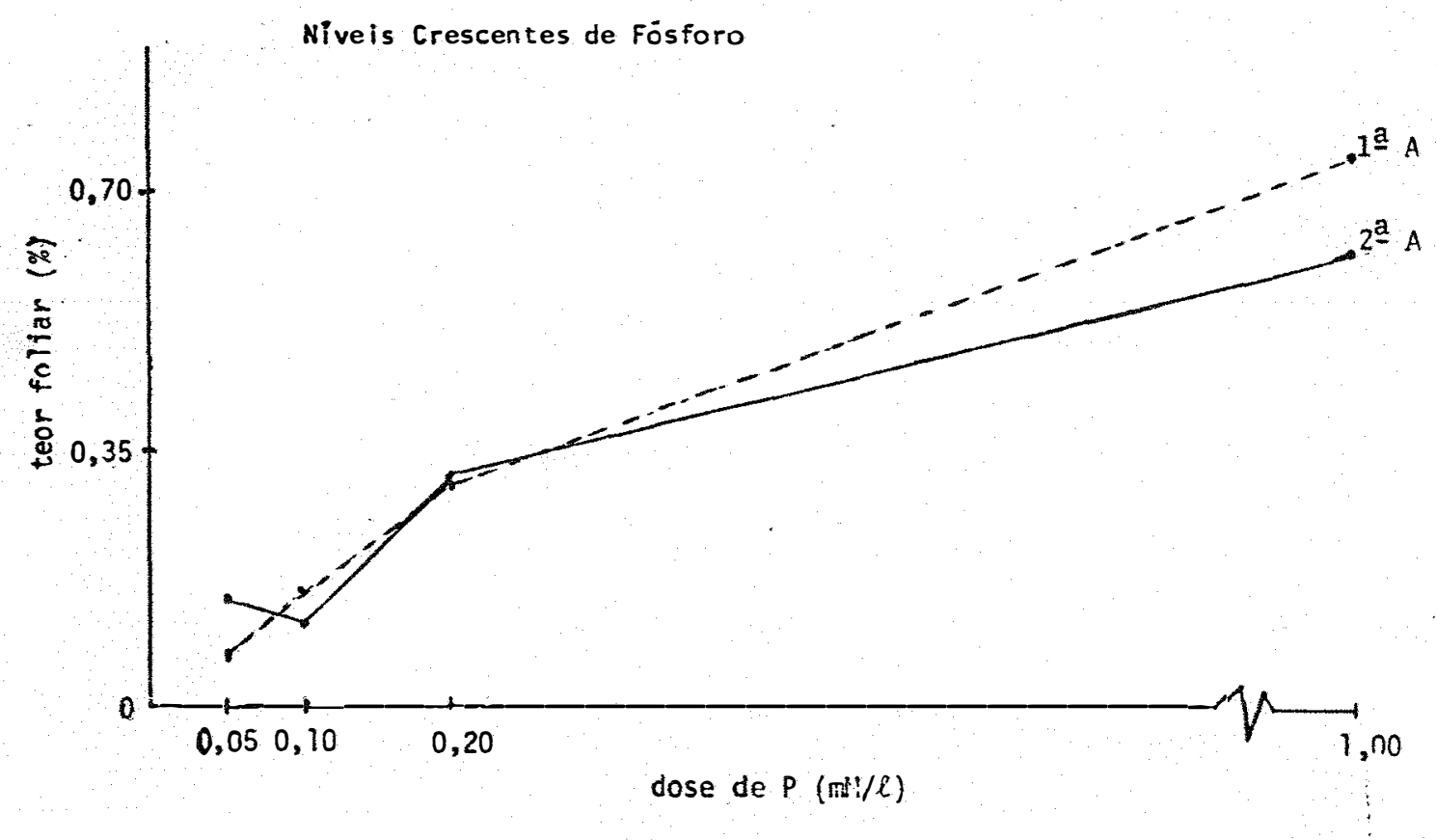

Figura 9. Relação entre dose e teor foliar. 
Nivels Crescentes de Fósforo

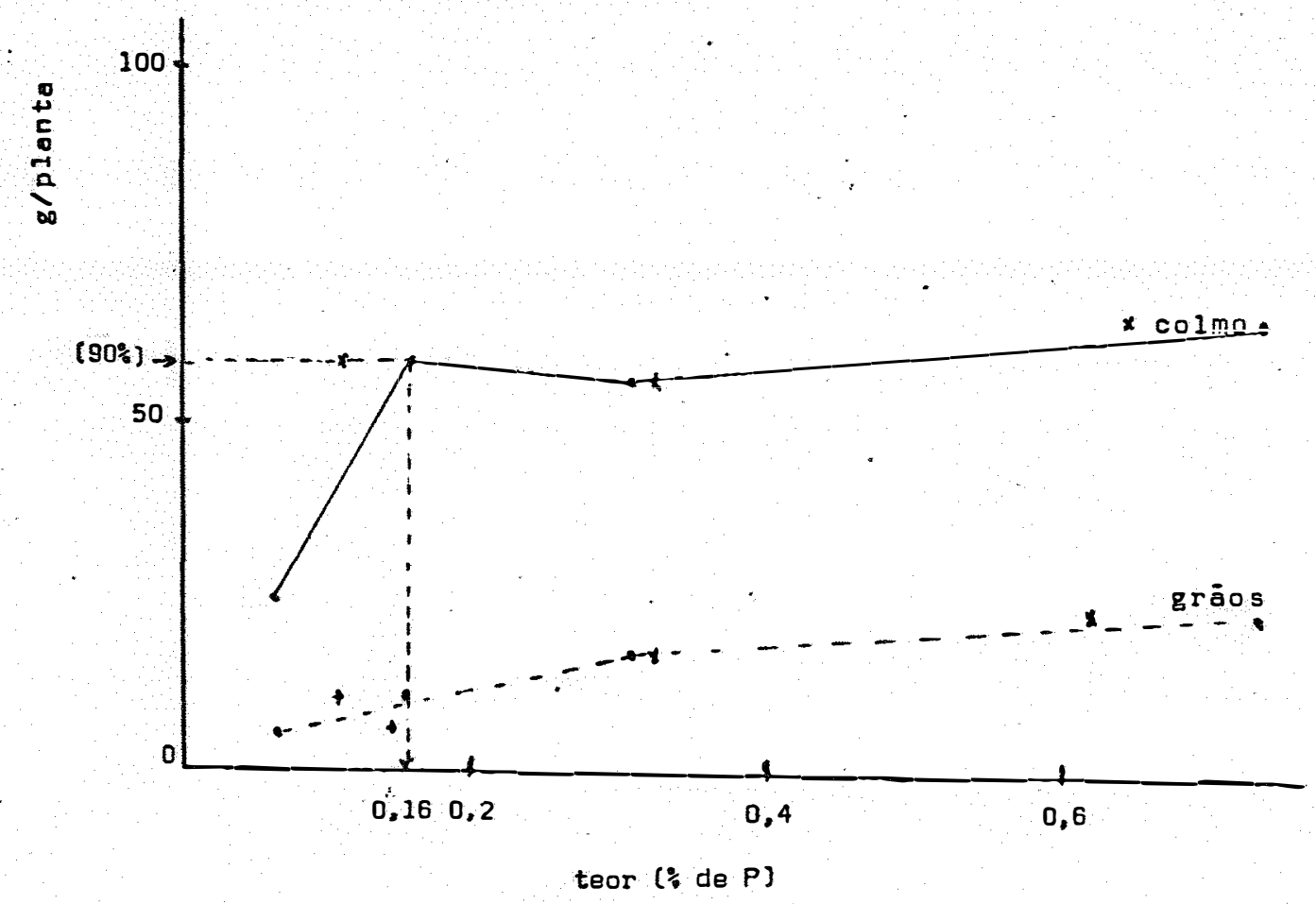

Figura 10. Relação entre teor foliar e produção de colmo seco.

Tabela 22. Análise dos componentes tecnológicos do sorgo saca rino cultivado em solução nutritiva com doses de fösforo.

Doses de fösforo

Componentes

\begin{tabular}{rrrr}
\hline $1: 20$ & $1: 10$ & $1: 5$ & $1: 1$ \\
\hline 55,11 & 55,95 & 68,85 & 58,75 \\
91,10 & 88,52 & 91,32 & 92,70 \\
12,38 & 13,71 & 8,12 & 10,94 \\
7,92 & 9,67 & 3,32 & 4,46 \\
9,96 & 11,48 & 8,67 & 7,29 \\
8,92 & 9,87 & 5,79 & 6,95 \\
0,57 & 1,14 & 2,14 & 2,44 \\
\hline
\end{tabular}


Tabela 23. Estímativa do rendimento em álcool etílico do sorgo sacarino cultivado em solução nutritiva com doses de fösforo.

Doses de fösforo

Rendimento

$\begin{array}{llll}1: 20 & 1: 10 & 1: 5 & 1: 1\end{array}$

$\mathrm{kg} \mathrm{caldo/t}$ colmo

$551 \quad 559$

636

587

kg caldo/ha

19285

19565

22260

20545

kg açücares totais/ha

1720

1931

1288

1428

$1 \mathrm{a} l \mathrm{cool} / \mathrm{t}$

27

31

20

23

lälcool/ha

954

1070

714

792

Na dose minima de $P$ o teor de açūcares totais

foi mais alto que o tratamento em dose mäxima. Isto pode sig nificar que pequena quantidade de $P$, é suficiente para obter um teor alto de açúcares totais.

Com respeito à produção de álcool por tonelada de colmo e por hectare, os valores estão bem abaixo dos obtidos por SERRA (1979).

ROSOLEM (1979) afirma que embora os teores de sacarose, açūcares redutores, açūcares totais e fibra sejam caracteristicas importantes, a produção de colmos parece ser de maior significância para a produção de àlcool/ha, com respeito a adubação. Entretanto, na condição deste ensaio, os 
resultados demonstraram que a produção de álcool por área pe lo sorgo sacarino é uma função principal dos teores de açúcares totais.

4.5. Efeito das doses de potássio.

$4 \cdot 5 \cdot 1$. Sintomas

\begin{abstract}
A manifestação dos primeiros sintomas de carência se deu aos 30 dias após o transplante em solução de tratamento.

os sintomas foram idênticos ao mencionado no item 4.1.1. Apareceram sintomas nas plantas em todos os niveis de $K$, exceto no tratamento "completo".
\end{abstract}

\title{
4.5.2. Dados fenológicos
}

Na Tabela 24, verifica-se que o peso da matéria fresca do colmo cresceu à medida que se elevou a concentração de k na solução nutritiva, o que reflete os aumentos verificados tanto na altura quanto no diâmetro do colmo. A observação mostra coerência com o que se conhece na literatura a respeito do papel do $K$ no crescimento vegetativo. 
Tabela 24. Matéria fresca, comprimento e diámetro dos colmos das plantas de sorgo sacarino cultivadas em solução nutritiva com doses de potássio.

\begin{tabular}{cccc}
\hline Doses de & Matëria fresca & Comprimento & Diâmetro \\
K & $(\mathrm{g})$ & $(\mathrm{cm})$ & $(\mathrm{cm})$ \\
\hline $1: 20$ & $109,91 \mathrm{~d}$ & $141,00 \mathrm{~d}$ & $1,25 \mathrm{c}$ \\
$1: 10$ & $183,59 \mathrm{c}$ & $165,25 \mathrm{c}$ & $1,95 \mathrm{~b}$ \\
$1: 5$ & $225,01 \mathrm{bc}$ & $181,75 \mathrm{~b}$ & $2,12 \mathrm{ab}$ \\
$1: 1$ & 283,19 a & $199,75 \mathrm{a}$ & $2,40 \mathrm{a}$ \\
\hline & $36,17 * *$ & $77,93^{*}$ & $33,23 * *$ \\
Tukey $5 \%(\mathrm{dms})$ & 51,21 & 11,88 & 0,36 \\
C.V. (\%) & 12,22 & 3,29 & 8,81 \\
\hline
\end{tabular}

* significativo ao nivel de $1 \%$

As mëdias seguidas da mesma letra não diferem entre si

4.5.3. Produção de matéria seca

Encontra-se na Tabela 25 os dados da matēria seca cotal e das partes das plantas submetidas a doses crescentes de $K$.

Percentualmente verifica-se que a deficiência de potássio afetou muito mais a produção de grãos que a do col mo: no tratamento com nível máximo na solução obteve-se $275 \%$ mais de colmo e $500 \%$ mais de grãos. 
A anàlise estatística mostrou que a produção de grãos calu à medida que diminula o K.

Como o K reconhecidamente afeta muito mais o crescimento vegetativo, o dado é surpreendente. Pode ser explicado admitindo-se menor transporte de produtos da fotossintese para o enchimento dos grãos nas condições de caréncia potásica.

Tabela 25. Matéria seca (g/vaso) total e das partes da planta de sorgo sacarino cultivadas em solução nutritiva com doses de potässio.

\begin{tabular}{|c|c|c|c|c|c|}
\hline Doses de $K$ & Ra iz & Colmo & Fol has & $\begin{array}{l}\text { Raquet } \\
\text { grãos }\end{array}$ & Total \\
\hline $1: 20$ & $6,74 \mathrm{~b}$ & $19,80 \mathrm{c}$ & $12,99 \mathrm{~b}$ & $5,00 d$ & $44,54 c$ \\
\hline $1: 10$ & 11,94 a & 29,48 bc & $19,04 a$ & $9,16 \mathrm{c}$ & $69,63 \mathrm{~b}$ \\
\hline $1: 5$ & 13,44 a & $32,22 b$ & 21,21 a & $15,69 \mathrm{~b}$ & $83,57 \mathrm{~b}$ \\
\hline $1: 1$ & 11,20 a & $54,56 a$ & 22,36 a & 25,06 a & 113,18 a \\
\hline$F$ & $10,69 * *$ & $28,22 * \star$ & $12,17 * *$ & $120,33 * *$ & $58,48 * *$ \\
\hline Tukey $5 \%(\mathrm{dms})$ & 3,69 & 11,59 & 5,04 & 3,35 & 15,72 \\
\hline C.V. $(\%)$ & 16,26 & 16,11 & 12,67 & 11,60 & 9,63 \\
\hline
\end{tabular}

** significativo ao nivel de $1 \%$

As médias seguidas da mesma letra não diferem entre si. 


\subsubsection{Diagnose foliar}

Na Tabela 26, encontram-se os teores de macronutrientes nas folhas medianas das plantas submetidas a trata mento de K em duas ëpocas de amostragem.

Na Figura 11 observa-se o estado nutricional sob influência dos diversos níveis de k no substrato.

$0 \mathrm{~s}$ teores de $K$ encontrados nos tratamentos $1: 10$ e $1: 5$ de $k$, não diferiram estatisticamente nas 2 amostragens realizadas. Para o teor de Ca, o tratamento completo de K cau sou sensível decrëscimo.

A interação mais frequente observada para o $K$ e outros cātions refere-se ao $\mathrm{Ca}$ e $\mathrm{Mg}$.

Vảrios autores têm feito referências com respeito a essa inibição e antagonismo (MEllo et alii , 1966; EPSTEIN, 1975; MALAVOLTA, 1980; OLOGUNDE e SORENSEN, 1982).

A Figura 11 mostra esses desequilibrios de modo acentuado.

Na Tabela 27. são apresentadas as relações K/ Ca e K/Mg obtidas com os níveis crescentes de $K$.

0 efeito dos tratamentos se exprimiu melhor atra vës dessas relações do que pelos teores percentuais de K isoladamente. 0 teor de K das plantas "normais" encontra-se prọ ximo ao valor encontrado por ROSOLEM (1979).

0 desenvolvimento do colmo foi máximo nesses tratamentos quando as relações $\mathrm{K} / \mathrm{Ca}$ e $\mathrm{K} / \mathrm{Mg}$ foram elevadas: a 


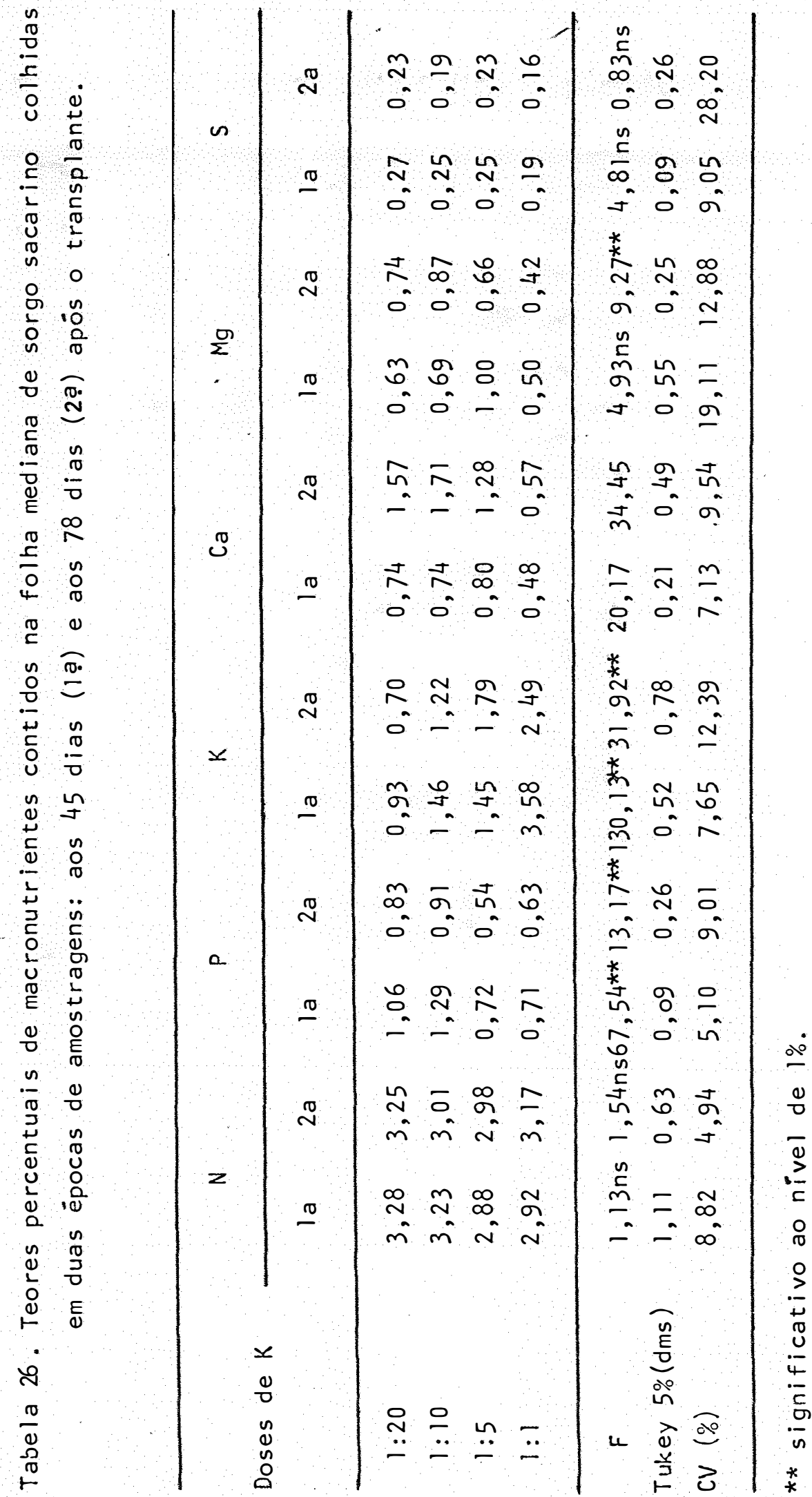



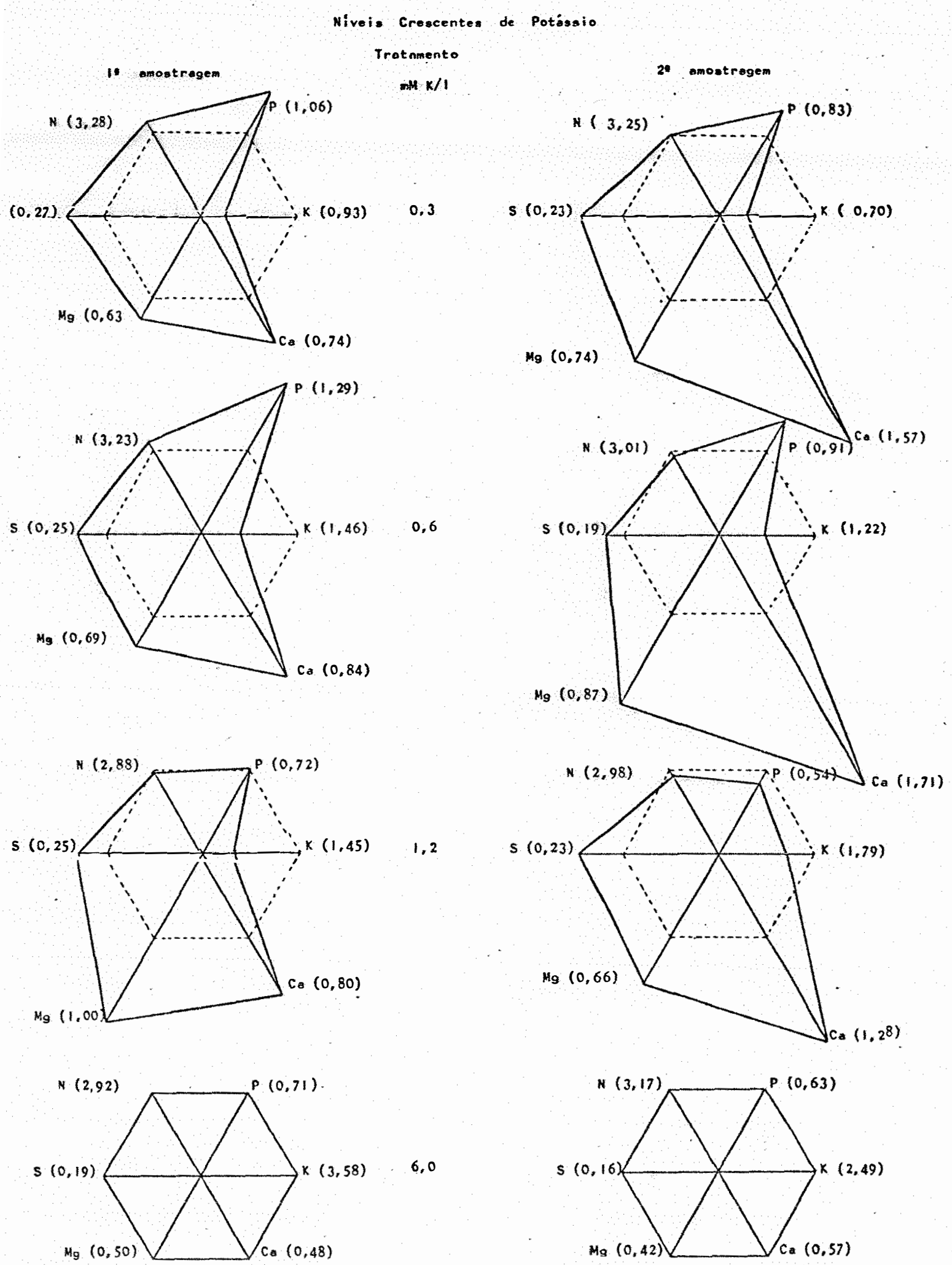

Figura 11. Representação hexagonal dos teores (\%) de macronutrientes encontrados nas folhas medianas de sorgo sacarino cultivado em solução nutritiva com doses de $K$, aos 45 e 78 dias apōs o transplante. 
faixa esteve entre 7,75 a 4,36 e 7,16 a 5,92 , respectivamente $($ Tabela 27$)$.

A acumulação de Ca na folha foi mais alta na 2a amostragem, podendo ser explicado pela imobilidade do Ca no floema segundo EPSTEIN (1975) e MALAVOLTA (1980).

Em vista dos resultados obtidos, considerando um certo antagonismo que existe entre as absorções de Ca e Mg e inibição entre as absorções de K e Ca (BERTHOULY e GUERRIER, 1979), o baixo nível de K, estimulou a acumulação do Cá e do $\mathrm{Mg}$.

Quanto às premissas da diagnose foliar as Figu ras 12,13 e 14 indicam que foram satisfeitas.

0 teor crítico associado com $90 \%$ de produção de colmo encontra-se pröximo a $2,9 \%$.

Tabella 27. Relação K/ca e K/Mg obtidas através das concentrações nas folhas medianas de sorgo sacarino co Ihidas em duas épocas de amostragens: aos 45 dias (1a) e aos 78 dias (2ạ) apös o transplante.

\begin{tabular}{lcccc}
\hline Doses de K & K/Ca & $2 a$ & 19 & K/Mg \\
& $19 a$ \\
$1: 20$ & 1,25 & 0,44 & 1,47 & 0,94 \\
$1: 10$ & 1,73 & 0,71 & 2,11 & 1,40 \\
$1: 5$ & 1,81 & 1,39 & 1,45 & 2,71 \\
$1: 1$ & 7,75 & 4,36 & 7,16 & 5,92 \\
\hline
\end{tabular}


77.

\section{Niveis Crescentes de Potássio}

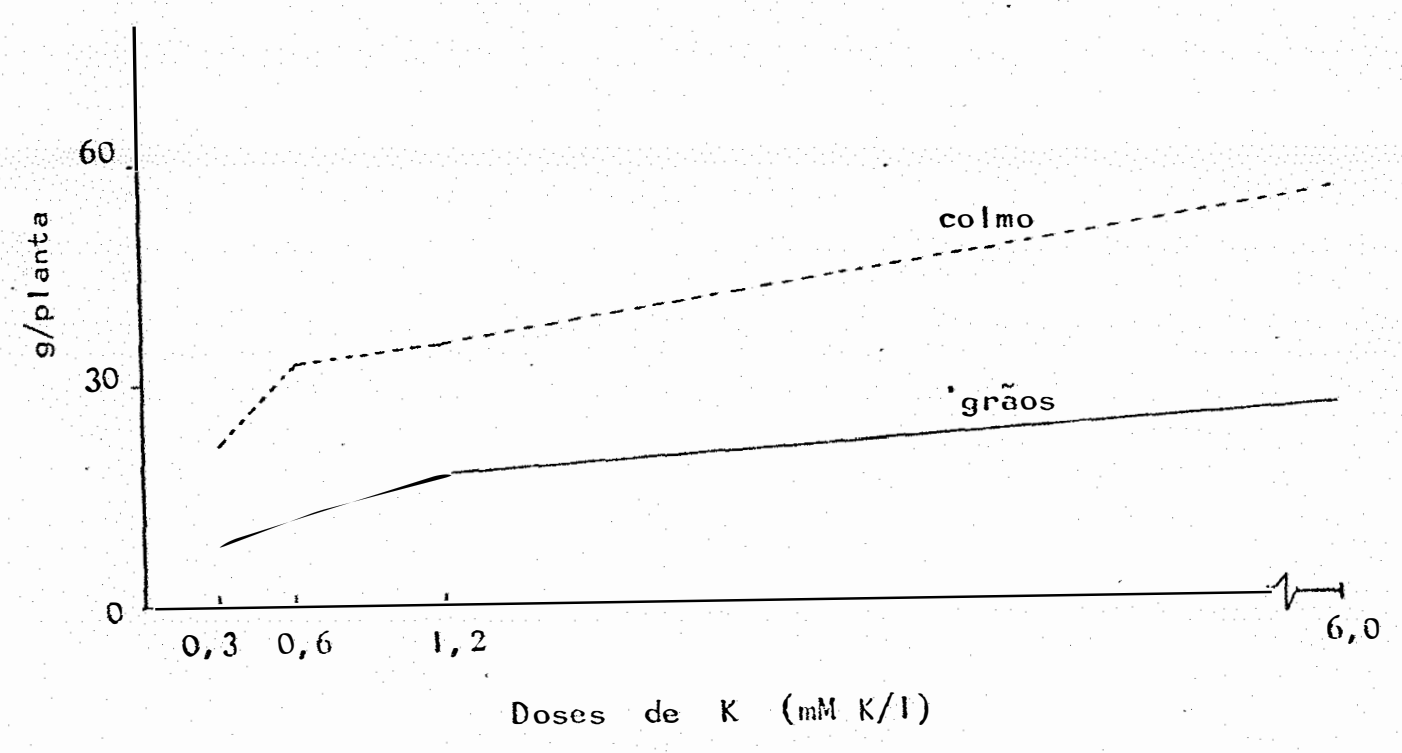

Figura 12. Relação entre dose e produção de colmo e grão.

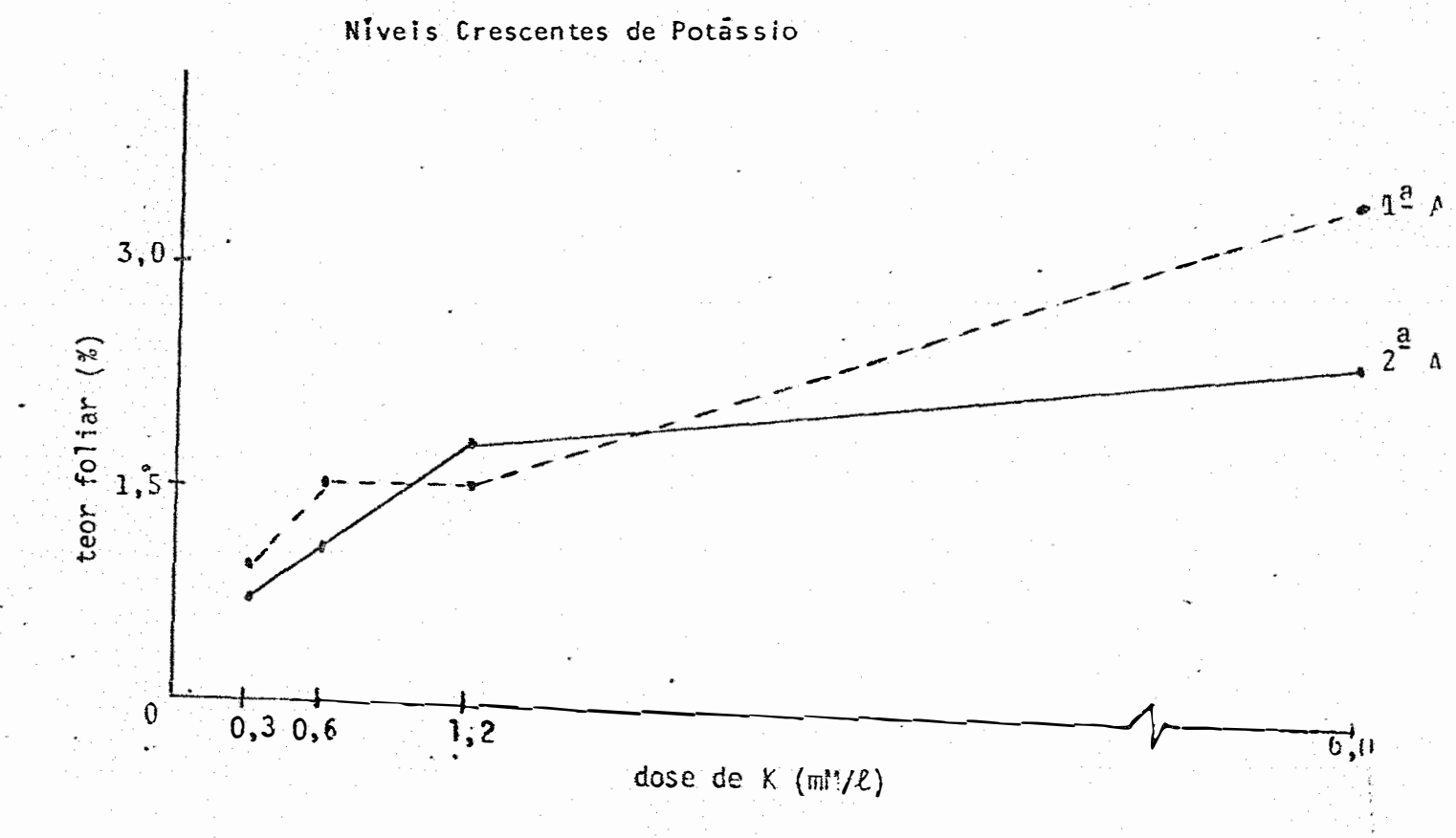

Figura 13. Relação entre dose e teor foliar. 
78.

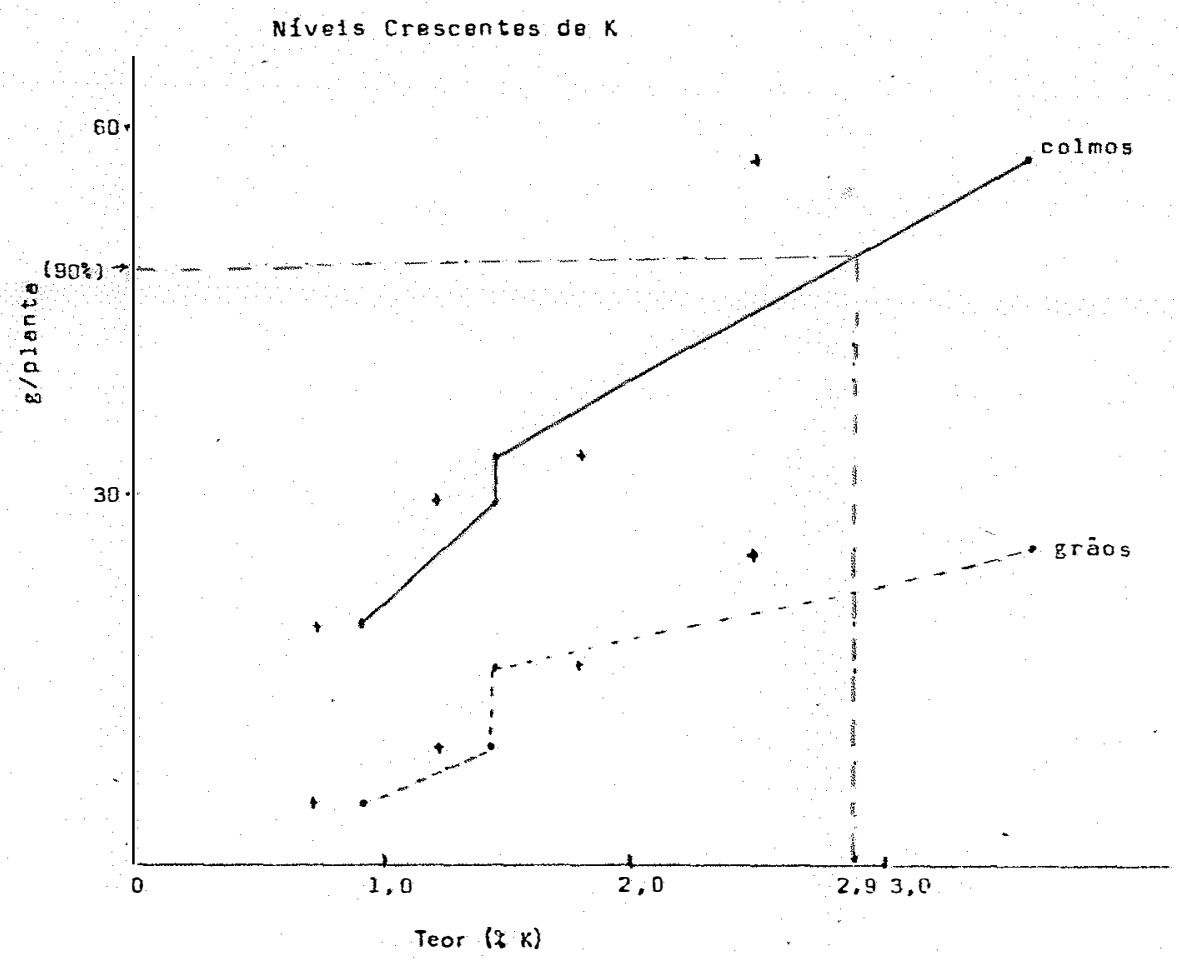

Figura 14. Relação entre teor e produção de colmos e grãos.

\subsubsection{Anälise Tecnolögica}

Nas Tabelas 28 e 29, encontram-se, respectivamen te, os valores dos componentes tecnológicos e cälculo estimado do rendimento alcoólico do sorgo sacarino, submetido a doses crescentes de potássio.

Foi possivel verificar, neste caso, redução no teor de açücares à medida que se diminuiu o nível de $k$, o que estä de acordo com HARTt (1934) e HAAG (1965). - efeito pode ser devido à diminuição na atividade fotossíntese ou à translocação das folhas para os colmos ou ambas as coisas (MA LAVOLTA et alii, 1974). 
Embora os teores dos componentes tecnológicos se encontrem abaixo dos obtidos por SERRA (1979), nota-se que - Kapresentou efeito quando fornecido em dose mais elevada (Tabela 30$)$

Tabela 28. Anälises dos componentes tecnolögicos do sorgo sacarino, cultivado em solução nutritiva com doses de potássio.

\begin{tabular}{llllc}
\hline & & & & \\
& & & \\
& & & \\
& $1: 20$ & $1: 10$ & $1: 5$ & $1: 1$ \\
& & & & \\
\hline & 54,70 & 53,48 & 49,82 & 53,69 \\
Peso do caldo \% & 90,89 & 93,02 & 93,64 & 93,28 \\
Caldo Absoluto \% sorgo & 7,95 & 8,79 & 7,49 & 9,33 \\
Brix sorgo & 1,25 & 2,09 & 1,30 & 4,60 \\
Pol sorgo & 9,10 & 6,97 & 6,36 & 6,71 \\
Fibra \% sorgo & 3,88 & 5,24 & 4,21 & 7,15 \\
Açücares Totais\% CE & 2,62 & 3,03 & 2,78 & 2,44 \\
Açücares Redutores \% CE & & & & \\
\hline
\end{tabular}


Tabela 29. Estimativa do rendimento de álcool etílico do sorgo sacarino cultivado em solução nutritiva com doses de notássio.

\begin{tabular}{|c|c|c|c|c|}
\hline \multirow{2}{*}{ Rendimento } & \multicolumn{4}{|c|}{ Doses de potássio } \\
\hline & $1: 20$ & $1: 10$ & $1: 5$ & $1: 1$ \\
\hline $\mathrm{kg} c \mathrm{caldo} / \mathrm{t}$ colmo & 547 & 535 & 498 & 537 \\
\hline $\mathrm{kg} \mathrm{caldo/ha}$ & 19145 & 18725 & 17430 & 18795 \\
\hline kg açucares totais/ha & 743 & 981 & 734 & 1344 \\
\hline $1 \mathrm{a} l \mathrm{cool} / \mathrm{t}$ & 12 & 15 & 12 & 21 \\
\hline 1 álcool/ha & 412 & 544 & 407 & 745 \\
\hline
\end{tabular}

Tabela 30. Regressões entre nível de K na solução e característica tecnolögica.

\begin{tabular}{llll} 
Caracteristica & \multicolumn{1}{c}{ Equação } & $F$ & $R^{2}(\%)$ \\
\hline Peso do caldo & $y=57,00-7,199 x+1,107 x^{2}$ & 28,4 & 98 \\
Caldo absoluto & $y=90,30+8,63 x-0,523 x^{2}$ & 2,3 & 82 \\
Brix & $y=8,644-0,991 x+0,1-1 x^{2}$ & 1,0 & 67 \\
Pol & $y=1,673-0,296 x+0,130 x^{2}$ & 7,5 & 94 \\
Fibra & $y=9,679-3,618 x+0,52 x^{2}$ & 2,8 & 82 \\
Açücares totais & $y=4,381+0,0248 x+0,72 x^{2}$ & 2,7 & 84 \\
Açücares redutores & $y=2,716+0,166 x-0,035 x^{2}$ & 0,68 & 58
\end{tabular}




\section{CONCLUSÕES}

A cultivar Brandes de sorgo sacarino foi culti vada em solução nutritiva em três experimentos independentes.

As principais conclusões foram as seguintes:

(1) Ensaio preliminar com niveis variāveis de $k$ :

(a) a produção de matēria seca de colmo cresceu com a dose de $K$, a maior sendo observa da com a metade do nível máximo fornecido;

(b) o peso maior de grãos, entretanto, foi ob-tido quando se empregou a concentração maior de potássio;

(c) a elevação no suprimento de $K$ fez crescer o teor foliar do mesmo, o que foi acompanha do por diminuição nos teores de Ca é, em menor grau, de $\mathrm{Mg}$;

(d) o menor fornecimento de K determinou diminuição na quantidade de caldo, no Brix e fibra, havendo elevação da \% de açūcares redu tores totais, açücares redutores e sacarose, porēm diminuição na quantidade em valores absolutos; 
(e) as exigências nutricionais obedeceram à se guinte ordem decrescente: $K, \mathrm{~N}, \mathrm{Ca}, \mathrm{S}, \mathrm{P}$, $\mathrm{Mg}, \mathrm{Fe}, \mathrm{Mn}, \mathrm{Zn}, \mathrm{B}, \mathrm{Cu}$ e Mo.

(2) Ensaio com niveis de $\mathrm{K}$ e $\mathrm{Mg}$ :

(a) a combinação de niveis intermediários de $k$ e Mg determinou a maior produção de colmos;

(b) a presença do K em maior nivel na solução causou as reduções mais acentuadas no peso dos colmos independentemente da concentração de $\mathrm{Mg}$ fornecida;

(c) os teores foliares de $\mathrm{K}$ e Mg cresceram com o aumento na concentração dos mesmos no substrato até o nível intermediârio;

(d) a elevação no fornecimento de K, mas não a correspondente ao $\mathrm{Mg}$, provocou tendência pa ra queda no teor de $\mathrm{Ca}$;

(e) não houve variação consistente no Breix em consequência dos tratamentos.

(3) Niveis variáveis de $N, P$ e K:

(a) os sintomas de deficiência concordam com os da literatura;

(b) O $\mathrm{N}$ aumentou linearmente a matéria fresca dos colmos, tendo aumentado a altura e o diâmetro dos mesmos;

(c) houve relação direta entre fornecimento de $N$ e teor teor foliar entre fornecimento e produção de matéria fresca e seca, bem como entre teor foliar e produção; 
(d) o estado nutricional foi mais relacionado com o teor foliar de $N$ do que com os quocientes $N / P$ e $N / S$;

(e) a produção relativa de colmos igual a $90 \%$ foi obtida com o nivel $3 \%$ de $N$ na fol ha;

(f) os teores de açūcares totais foram diminuídos pelos níveis mínimo e máximo de $\mathrm{N}$; enquanto os dos redutores mostraram tendên cia para crescer;

(g) o rendimento estimado de àlcool etilicofoi menor no nivel mais baixo de $\mathrm{N}$;

(h) houve um efeito linear do fornecimento de P sobre a matéria fresca produzida;

(i) o teor foliar de p aumentou com o nivel do mesmo aplicado na solução, atingindo teores que caracterizam alimentação de luxo, sendo certo que tais teores e a relação N/P crescem o mesmo número de vezes;

(j) o teor foliar de P considerado adequado pá ra uma produção relativa de colmos igual a $90 \%$ foi de $0,16 \%$;

(1) o aumento no, fornecimento de P causou dimi nuição na Pol, fibra, açūcares totais e crescimento no teor de açúcares redutores;

(m) a produção de colmo e de grãos cresceu linearmente com o suprimento de $K$ no meio;

(n) o teor foliar de K aumentou com a dose for necida, o que fez cair a relação K/Ca e K/ $\mathrm{Mg}$; 
(o) o teor foliar de $29 \%$ de K correspondeu a $90 \%$ da produção relativa de colmos;

(p) o Brix, a pol e os açúcares totais diminui ram à medida que cresceu a concentração de $K$ no meio, havendo tendência oposta com respeito à \% de fibra; o rendimento alcoólico estimado cresceu com o suprimento de K. 
85.

\section{LITERATURA CITADA}

AMORIM, H.V. e E.A. ZAGO, 1978. Análise para controle da fer mentação alcoólica. Mimeogr. ESALQ/USP. Piracicaba-SP.

BERTHOULY, M. e G. GUERRIER, 1979. Interactions calcium potassium - magnesium chez le sorgho-grain. 1 - Influence d' une carence en calcium sur la distribution de ces elements. Comm. Soil Sci.Pl. Anal.. New York, 10(12): 15231539 .

BERTHOULY, M. e G. GUERRIER, 1979. Interactions calcium-magnesium - potassium chez le sorgho-grain. 2 - Influence d' une carence en magnesium sur la distribution de ces elements. Comm. Soil Sci. Pl. Anal.. New York, 10(12): $15+1-1556$.

BERTHOULY, M. e G. GUERRIER, 1979. Interactions calcium-potas sium - magnesium chez le sorgho-grain. 3 - Influence d' une carence en potassium sur la distribution de ces elements. Comm. Soil Sci. Pl. Anal... New York, 10(12): $1557-1571$. 
BLACK, C.A., 1975. Relaciones Suelo-Planta. Vol. 2. Buenos Aires, Hemisfério Sur Editora. 866 p.

CORDEIRO, D.S.; A.N. KICHEL; P. SILVĖIRA Jr., 1982. Efeito de doses crescentes de potássio em sorgo sacarino. In: CON GRESSO NACIONAL DE MILHO E SORGO, 14\%, Florianópolis - SC. Resumos.P. 167 .

COUTINHO, E.L.M., 1983. Efeito da adubação nitrogenada, fosfatada e potássica na cultura do sorgo sacarino (Sorghum bicolor L. Hoench.), avaliada pela diagnose foliar, produção de colmos e àlcool etilico. Piracicaba, ESALQ/USP, 189p. (Tese de Doutoramento).

DECHEVA, R.; G. ZOLOTOVICH e D. KOSSEVA, 1970. "Effect of mi neral elements on nitrogen, phosphorus, potassium, amino acid and sugar content in (Rosa damascena Mill)". C.R.Acad. sci. Hort. Abst., $40(2): 841$.

EMPRESA BRASILEIRA DE PESQUISA AGROPECUARIA, 1977. Lançamento de novos cultivares. Brasilia, DF.

EPPENDORFER, W.H., 1971. Effects of $S, N$ and $P$ on amino acid composition of field beans (vicia faba) and responses of the biological value of the seed protein to 5 -amino and con tent. J.Sci. Food. Agr., 22: 501-505.

EPSTEdN, E., 1975. Nutrição mineral das plantas: princípios e perspectivas. Ed. USP. São Paulo. $341 \mathrm{p}$.

ESTEVES, A.L.; C.B. BAGGIO; F.A. COSTA; H.F. CASTRO, 1981. Efeitos da época de plantio em dez cultivares de sorgo sacarino. Inf. Inst. Nac. Tec. Rio de Janeiro, 14 (25): $26-$ 44.

FONTES, L.A.N. e W.M. FILHO, 1979. Calagem e adubação do sor go. Inf. Agropec. Belo Horizónte, 5(56): 17-21. 
GOMES, E.P., 1973. Curso deEstatistica Experimental. 5 a ed. São Paulo, Nobel, 430 p.

HAAG, H.P., 1965. Estudos de nutrição mineral da cana-de-açücar variedade CB 41-76 cult ivada em solução nutritiva. Piracicaba, ESALQ /USP. 141p. (Dissertação de Mestrado).

HARTT, C.E., 1934. Some effects of potassium upon the amounts of protein and amino from of nitrogen, sugar and enzime ac tivity of sugar cane. Plant Physiol. Bethesda, 9: 453-490.

HIPP, B.W.; W.R. COWLEY; C.J. GERARD e B.A. SMITH, 1970. Influence of solar radiation and date of planting on yield of sweet sorghum. Crop. Science. Madison, 10 (1): 91-92.

HOAGLAND, D.R. e D.I. ARNON, 1950. The water culture method for growing plants without soil. Calif. Agr. Expt. Sta. circ. $34 \mathrm{p}$.

LANE, J.H. e L. EYNON, 1934. Determination of reducind sugars by Febling's solution with methyleneblue indicador. London, England, $8 p$.

MACHADO, J.R.; J. NAKAGAWA; C.A. ROSOLEM E 0. BRINHOLI, 1982 . Efeitos de espaçamento entre linhas e de niveis de adubação no comportamento de sorgo sacarino em latossol Roxo. Experimento IV. In: CONGRESSO NACIONAL DE MILHO E SORGO, 14:. Florianópolis-sC. Resumos. P.128.

MALAVOLTA, E. e H.P. HAAG, 1964. Nutrição e adubação. Em: Cultura e Adubação da cana-de-açūcar, ed. Inst. Bras. da Potassa. São Paulo. P.237-278.

MALAVOLTA, E.; H.P. HAAG; F.A.F, MELLO e M.O.C. BRASIL SOBR:, 1974. Nutrição Mineral e Adubação de Plantas Cultivadas. S. Paulo. Ed. Pioneira, p.259-90. 
MALAVOLTA, E.; E.L.M. COUTINHO; G.C. VITTI;N.V. ALEJO;N.J. NOVAES e V.L. FURLANI NETO, 1979. Estudos sobre a nutrição mineral do sorgo sacarino. I. Deficiências de macro e micronutrientes e toxidez de Al, Cl e Mn. Anais da ESALQ, XXXV1: $173-202$.

MALAVOLTA, E., 1980. Elementos de nutrição mineral de plantas. Sãopaulo, Ed. Agronómica ceres. $251 \mathrm{p}$.

MALAVOLTA, E. e S. LOURENÇO, 1978. Estudos sobre a nutrição mineral do sorgo granifero (Sorghum bicolor (L.) Moench.). 1 - Nota sobre o efeito das carências de macronutrientes no crescimento, produção e composição mineral. Reunião Brasileira de Milho e Sorgo, Xl, Anais. Paterniani, E. (ed.). P.iracicaba, p.691-700.

MEADE, G.P., 1967. Manual del Azücar de Caña. 9a. ed. Barcelona, Montaner y Simon. $940 \mathrm{p}$.

MEIRA, E.M., 1982. Adubação de manutenção e de correção em duas cultivares de sorgo sacarino (Sorghum bicolor (L.) Moench.). Areia, UFPb. 41 . (Dissertação de Graduação em Agronomia).

MELLO, F.A.F.; H.P. HAAG; M.O.C. BRASIL SOBR? e H.W.S. MONTENEGRO, 1966. A relação K/Mg em plantas jovens de laranjeira (Citrus sinensis L., var. P.A.C.). Anais da ESALQ; 23: $95-107$.

MENGEL, K. e K.A. KIRBY, 1982. Principles of plant nutrition. Bern, International Potash Institute. 655 .

OLOGUNDE, 0.0. E R.C. SORENSEN, 1982. Influence of concentrations of $K$ and $M g$ in nutrient solutions on sorghum. Agron. J. Madison: $74(1): 41-46$. 
OVERSTREET, R:; L. JACOBSON E R. HANDLEY, 1952. The effects of calcium on the absorption of potassium by barley roots. Plant Physiol. Bethesda, 27: 583-590.

QUINBY, J.R., 1967. The maturity genes of sorghum. Adv. Agron. New York, 19: 267-304.

RICAUD, R., 1971. Sweet sorghum for sugar production. In:Lousiana Agriculture. Lousiana State Univ., 14:4-7.

RODRIGUES, A.N.A., 1981. Adubação corretiva e de manutenção em sorgo sacarino (Sorghum bicolor ( $L$. ) Moench.). Areia, UfPb. 38p. (Dissertação de Graduação em Agronomia).

ROSOLEM, C.A., 1979. Contribuição ao estudo da nutrição mine ral e adubação do sorgo sacarino (Sorghum bicolor. Moench.). Piracicaba, ESALQ/USP.137p. (Tese de Doutoramen to).

ROSOLEH, C.A.; T. NOGIMOTO e J.R. MACHADO, 1982. Respostas do sorgo sacarino a adubos nitrogenado, fosfatado e potássico em um Latossol Roxo. In: CONGRESSO NACIONAL DE MILHO E SORGO, 14\%, Florianópolis-SC. Resumos. P.171.

ROSS, N.M. e D.J. WEBSTER, 1970. Fertilizers. Em: Cultureand use of grain sorghum. Agriculture Handbook 385 , U.S. Dept. of Agriculture, Washington. P.18-20.

SALLES FILHO, M.; H.G.B. SILVA; e V.M.S. SCHNEIDERMANN, 1977. Sorgo, matéria prima renovável para produção de etanol na escalada energética nacional. Brasil Acucareiro, 90 (2): $23-41$. 
SERRA, G.E.; M. LUDERS; T.C. ALMEIDA, 1976. Observações preliminares sobre características agronômicas e tecnolögicas do sorgo sacarino. In: REUNIÃO BRASILEIRA DE MILHO E SORGo, $11 \%$, Anais. ESALQ-Piracicaba.

SERRA, G.E., 1979. O sorgo sacarino como matéria-prima para a produção de àlcool etílico. In: SIMPOSIO BRASILEIRO DE SORGo, Brasilia. Anais. Brasilia, EMBRAPA/CNPMS, p.105-116.

SILVA, H., 1983. Efeitos da adubação do sorgo sacarino (Sorghum bicolor (L.) Moench.) na qualidade do caldo para multiplicação de leveduras e fermentação alcólica. Piracicaba, ISALQ/USP. 295p. (Tese de Doutoramento).

SOUZA, E.A.; A.L. ROSSETO Fo e R. BIANCO, 1976. Relações entre os teores do $\mathrm{K}, \mathrm{Ca}$ e Mg em Latossol Roxo cultivado com sorgo. In: Reunião Brasileira de Milho e Sorgo, 11 a, pira cicaba. Anais. p.707-715.

SUMNER, M.E., 1978. Interpretation of nutrient ratios in plant tissue. Comm: Soil Sci. Pl. Anal. New York, $\underline{9}(4): 335-345$.

TANIMOTO, T., 1964. The press method of cane analysis. $\mathrm{Ha}-$ waitian Planters Record, $57(2): 133-150$.

TEDRUS, P.F.A.S., 1982. Efeitos da adubação nitrogenada e fosfatada na cultura do sorgo sacarino (Sorghum bicolor (L.) Moench.), avaliada pela diagnose foliar, produção de colmos e älcool etilico. Jaboticabal, UNESP. 55p. (Dissertação de Graduação em Agronomia). 
ZAGATO,E.A.G.;A.0.JACINTHO;B.F.REIS;F.J. KRUG; H.B.FILHO; L.C.R. PESSENDA; J. MORTATTI E M.G. GINE, 1981 . Manual de Anälises de Plantas e Aguas Empregando Sistemas de Injeção em Fluxo. CENA/USP. $45 \mathrm{p}$.

ZANINI, J.R., 1982. Influência da maturação fisiológica na produção de sementes e no rendimento industrial da planta de sorgo sacarino (Sorghumbicolor (L.) Moench.). Piracica ba, ESALQ/USP. 137p. (Dissertação de Mestrado). 